A

DESCRIPIIVE CATALOG

$\mathrm{OF}$

\title{
VEGETABLES
}

FOR

\section{Canning and Quick Fremang}

No. 13

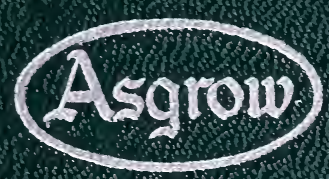

Associated Seed Growers, Ine

New Haven. Commectient 



\section{Foreword}

$\mathrm{T}$

$1 \mathrm{HE}$ present revision of our Descriptive Catalog would have appeared a year ago in normal circumstances. At that time, however, there were good reasons why its publication should be postponed, and these were not confined to the shortage of paper and other difficulties connected with printing. American agriculturists-including farmers, processors and their seedsmen-were under obligation, as their contribution to the successful prosecution of the war, to exert their maximum effort toward the production of greater tonnages than had ever before been raised in this or any other country.

To accomplish this despite the handicaps of reduced manpower, machinery, transportation, containers and similar necessities, many unusual measures were adopted; and among these was concentration on a somewhat limited list of standard, well-proven varieties, to crops of which some of the advantages of mass-production could be better applied. There was thus less occasion for the introduction or even the listing of new varieties while the wartime food production program was being energetically pursued.

Happily it was found possible not only to carry on but even to expand the program which has been continuously pursued for many years at the Asgrow breeding stations. The primary aim of this program is toward the highest standards of quality in the Asgrow strains of well-known varieties, the addition or enhancement of desirable characters, and the development of new types to meet specific needs, such as adaptation or resistance.

This edition includes many results of the program, and also reflects recent advances in the technique of food processing and preservation by the inclusion of varieties adapted to particular purposes. We shall welcome corrections, criticisms and suggestions which will help to make the descriptions of greater service to the industry we are privileged to serve.

\section{Associated Seed Growers, Inc.}

New Haven, Conn.

Feb. 1st, 1946. 


\section{The Asgrow Program of Research and Breeding}

The food standards of today are not satisfied by Nature's products as they would normally grow, unaided by man. Some plants, indeed, such as corn, could not continue to exist without cultivation, while others would revert to coarser forms unacceptable as food.

Particular conditions of environment, including soil, climate and the devastating effects of ever-increasing insects and diseases, demand new varieties or the adaption of others. Advancement in the knowledge and technique of preserving foods calls for types especially suited to canning, freezing and dehydrating. In addition, the quality of older varieties which are in general use for whatever purpose must continually be maintained, so that they may not deteriorate from their accepted standards.

Eight Asgrow breeding stations are now in operation, situated in as many different parts of the country, their locations having been determined by the needs of the species to be grown at each. The stations are charged with the following duties:

(1) The maintenance of high quality parent Asgrow stocks to be multiplied annually in seed crops destined for distribution to our customers.

(2) The production of new or improved types to meet special needs. Taking at random a few from the many, examples are Clark's Bush Lima bean, Pride and Canner King peas, the Asgrow strain of Golden Cross Bantam, and Golden Hybrid No. 2439 sweet corn.

(3) To cooperate with federal and state agricultural experiment stations.

(4) To determine the value of new or improved strains for particular localities.

(5) To render service to customers by the investigation of special problems or furnishing specific information.

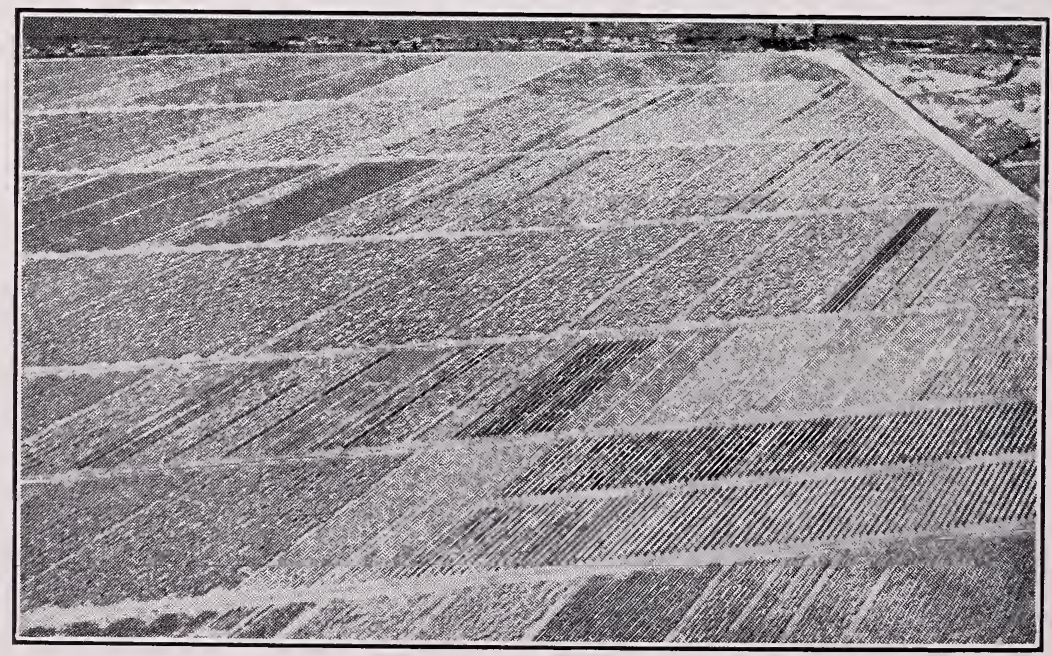




\section{The Asgrow Germination and Analytical Laboratory}

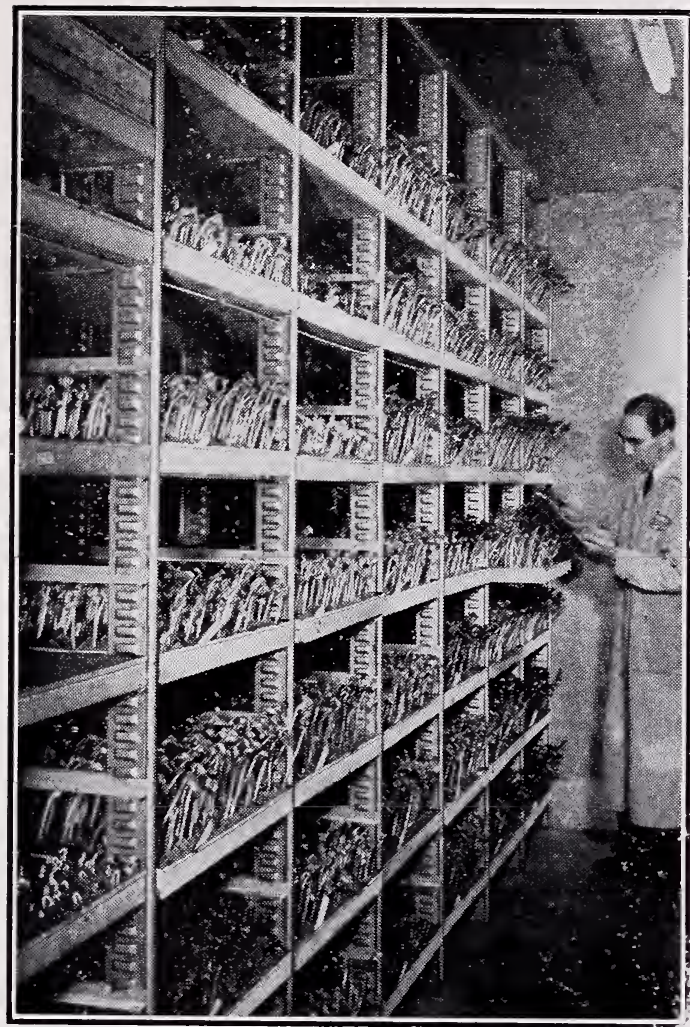

1. A partial view of the alternating temperature room germinators used for testing seed in sand or soil. Fluorescent light is used to allow chlorophyll production.
"Good" seed shall be (1) Viable, (2) Clean, (3) Disease-free, (4) true to type.

The most essential character of any lot of Asgrow seed is its ability to germinate and produce normal plants under average conditions.

One of the primary functions of a seed laboratory is that of determining seed viability so that such seed may be evaluated for use by our customers. Viability implies ability to germinate and grow when proper environmental conditions are provided. A seed may be considered to have germinated when it develops those structures which are commonly recognized in different varieties, species, or families of plants as essential to normal seedlings. Broken, malformed or other seedlings which are known to be incapable of producing plants under suitable laboratory conditions are to be considered as not having germinated.

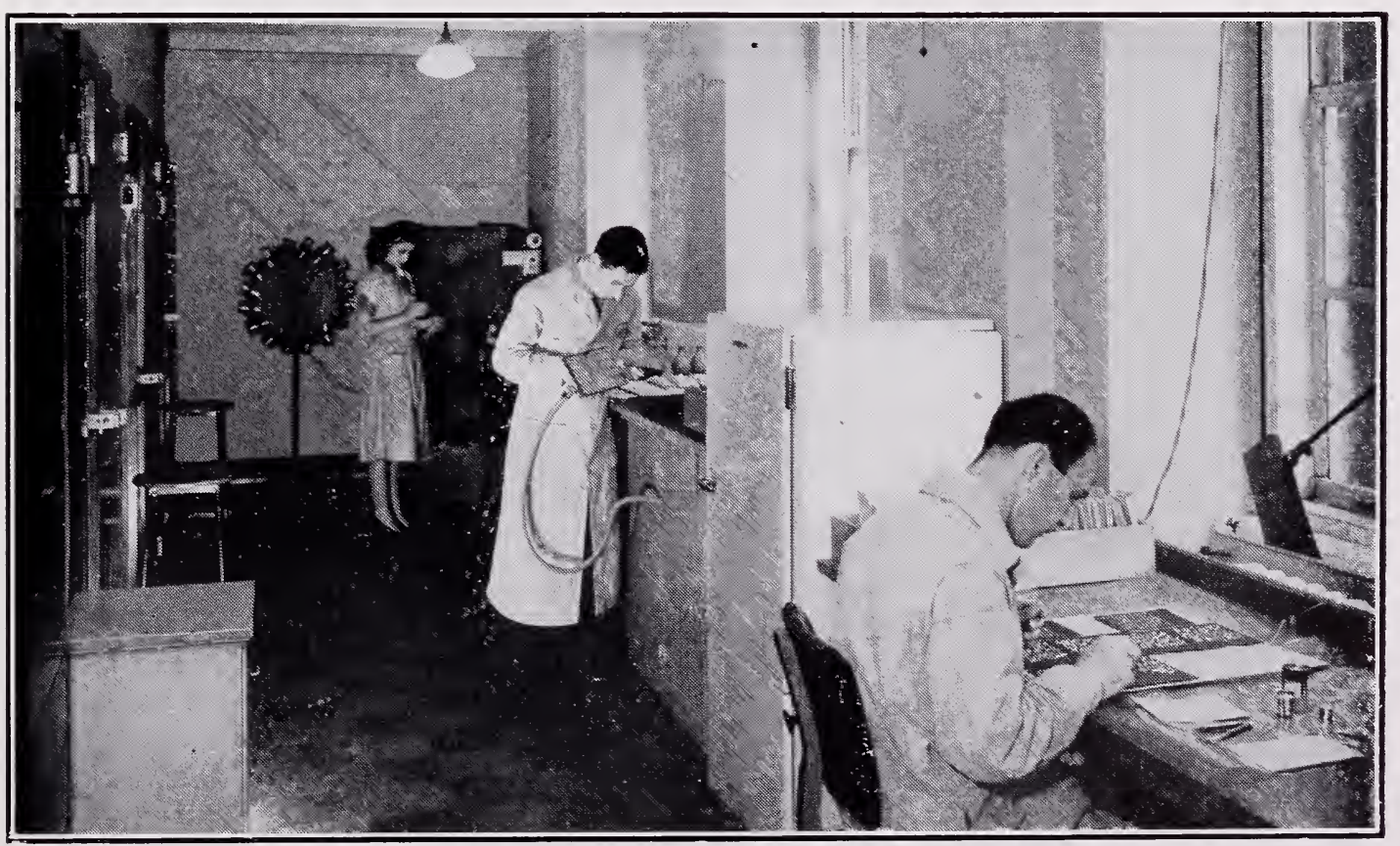

2. Part of the laboratory-the doors on the left lead to the germinating rooms. The analyst in the center of the picture is using a vacuum counter to count out and place 100 seeds on germination media. 


\section{The Asgrow Germination and Analytical Laboratory-Continued}

A second function of a seed laboratory is to determine the purity of a seed stock. This is accomplished by computing freedom from dirt, chaff, other crop seeds, and weed seeds. If weed seeds or other crop seeds are present, it is necessary to identify them accurately and to report if any noxious weeds are present.

A third function of a seed laboratory is to determine if seed may be contaminated either internally or externally with bacterial or fungous organisms that are pathogenic to the seed or the plants that are expected to develop from the seed.

The Asgrow germination and analytical laboratory located at New Haven, Connecticut, is properly equipped and staffed to perform these functions efficiently and on a large scale. In order that we may handle a large number of samples at any one time, we use "room" germinators (Fig. 1). These rooms are sealed with 2" to 3" of cork; the temperature and humidity are accurately controlled by thermostats and humidostats; and they are lighted by fluorescent lamps. One room is capable of holding 3,000 samples in duplicate when tested by the blotter method, or 670 samples in sand test.

The best equipment available is used in connection with the purity work (Fig. 3); Binoculars, Iowa air blast separators, sieves, Boerner seed sampler, Chain-o-matic Balance, and special Neon lighted counting plates.

Complete and accurate records are made and kept of all operations in the laboratory. These records are on permanent file, so that they may be referred to readily. Purity and germination samples are retained in a systematic file, usually for at least one year after the receipt of the sample in the laboratory.

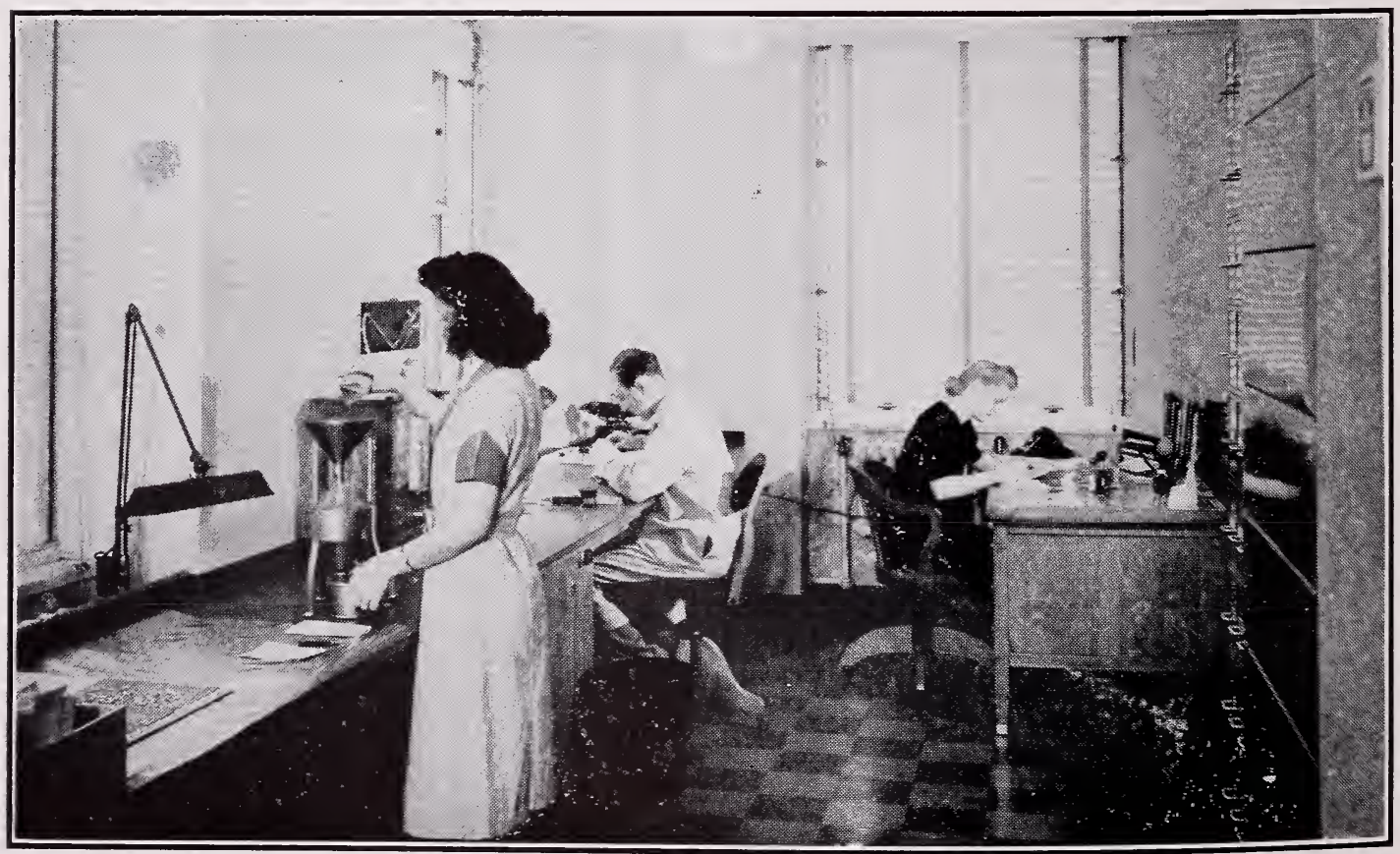

3. A part of the laboratory in which purity tests are conducted. 


\section{ALL-AMERICA ADSLCTIONS}

The All-America Selections Council, sponsored by the American Seed Trade Association, has each year since 1933 made awards to distinctively new varieties. These coveted awards are made on the results of trials conducted in eighteen different sections of the country by impartial judges, to whom the entries are known only by numbers, and who allot marks for Distinctiveness, General Usefulness, Adaptability, and Uniformity.

The Asgrow record in these trials is as follows:

\section{GOLD MEDAL}

Asgrow Stringless Green Pod Bean …............................................. 1933

Asgrow Wonder Beet ……................................................................ 1934

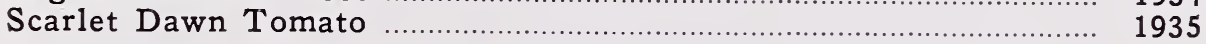

\section{SILVER MEDAL}

Asgrow Black Valentine Bean ....................................................... 1933

Clark's Special Cucumber ……................................................................ 1933

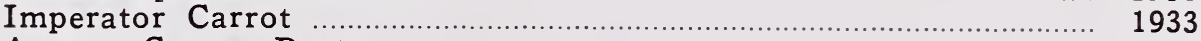

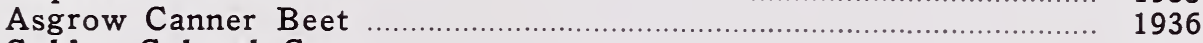

Golden Colonel Corn ........................................................................ 1936

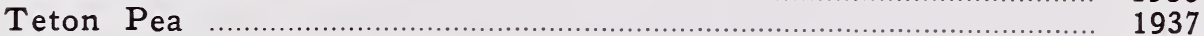

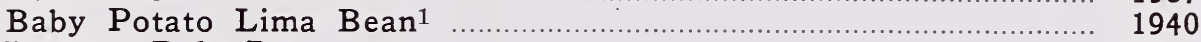

Decatur Pole Bean .......................................................................... 1942

BRONZE MEDAL

Stowell's Evergreen Hybrid Sweet Corn ....................................... 1934

Ruby King Pepper, Asgrow Strain ..................................................... 1935

Canner King Pea ...................................................................... 1937

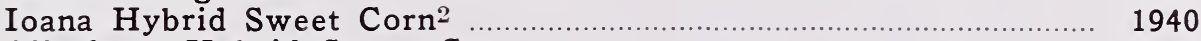

Allegheny Hybrid Sweet Corn ……...................................................... 1941

Medal Refugee Bean ............................................................... 1942

Marketer Cucumber …............................................................... 1943

Potomac Pole Bean ....................................................................... 1943

Cubit Cucumber ..................................................................... 1944

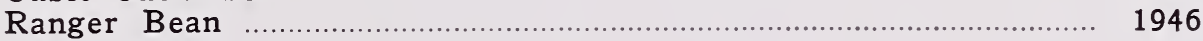

HONORABLE MENTION

Cardinal Tomato

1938

${ }^{1}$ Cooperatively, see page $11 . \quad{ }^{2}$ Cooperatively, see page 21.

\section{LARGE GREEN GLOBE}

\section{ARTICHOKE}

Plants thistle-like 3-5 ft. tall. Heads large, round but slightly elongated, deep green; edible base of scales thick and of delicate flavor.

\section{$\star$ MARY WASHINGTON}

\section{ASPARAGUS}

Developed by the late Dr. J. B. Norton, U. S. Dept. of Agriculture, for resistance to asparagus rust; and now by far the most extensively grown variety. Large green spears with tight, purple-tinted tips, of fine quality. Heavily productive and very uniform. 


\section{BEANS}

Through hybridization and intensive selection we have developed many of the leading varieties of stringless beans. In addition to creating new and better types at our breeding stations, a continuous program of pure-line breeding is carried on, so that Asgrow stocks of standard varieties may be maintained at their best.

DAYS: In listing the number of days from planting to marketable condition, we have used the average results secured over a period of years. These figures apply to plantings under normal conditions, and will vary somewhat in different sections of the country, but the number of days indicated will serve to show the relative maturity of the different varieties.

\section{GREEN PODDED: Dwarf or Bush}

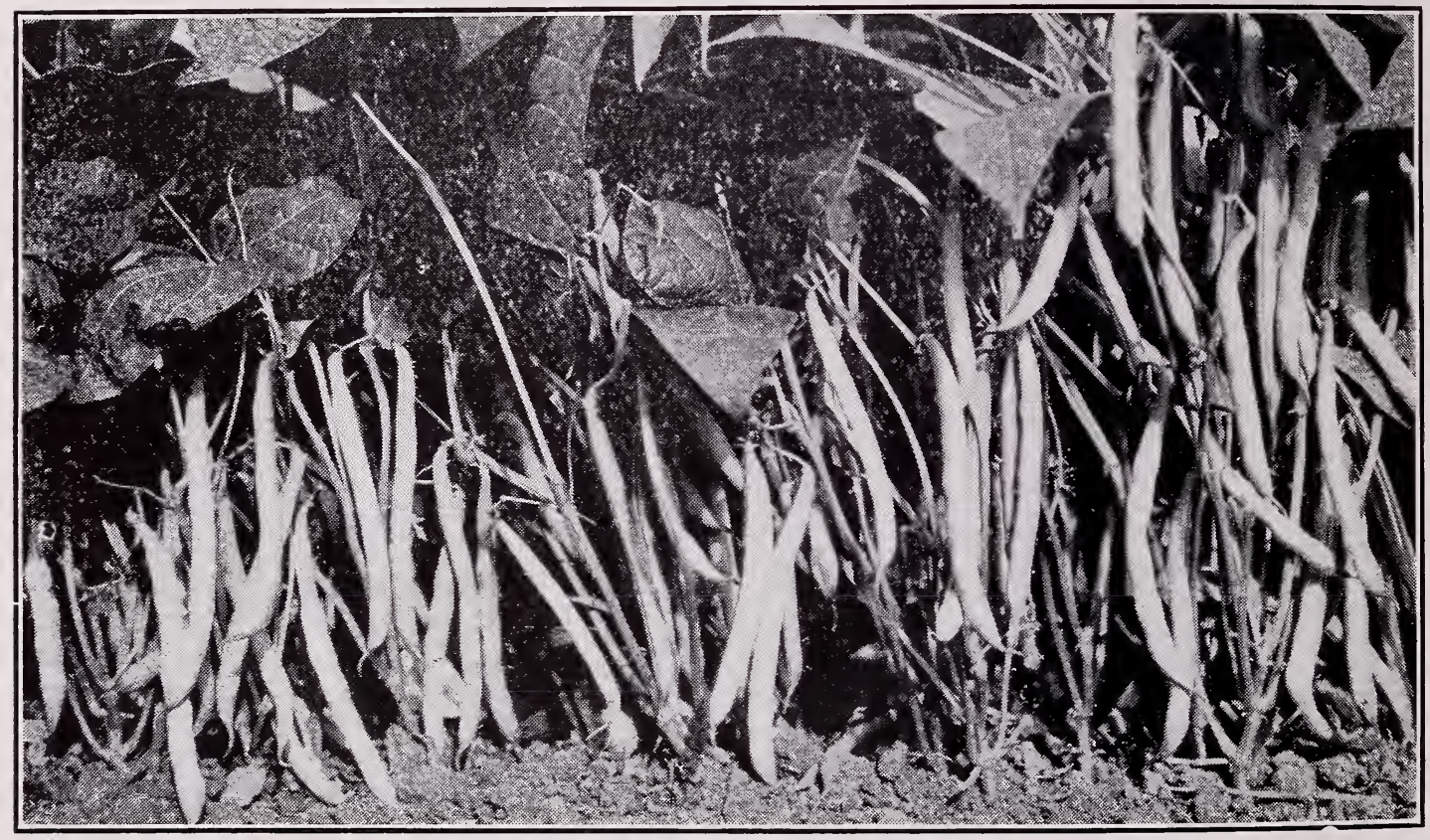

Asgrow Stringless Green Pod: The leading variety for canning

^ ASGROW STRINGLESS GREEN POD (Tendergreen)

All-America Gold Medal for 1933; one of the most popular varieties for canning and quick freezing. Hardy, widely adapted and a very dependable cropper. Plant medium large, erect, somewhat thick stemmed, heavily productive. Pods nearly straight, dark green, round, meaty, succulent; entirely stringless, without fiber, of outstanding quality. Seed oblong, purple mottling on buff with brownish cast: 65 per oz. 


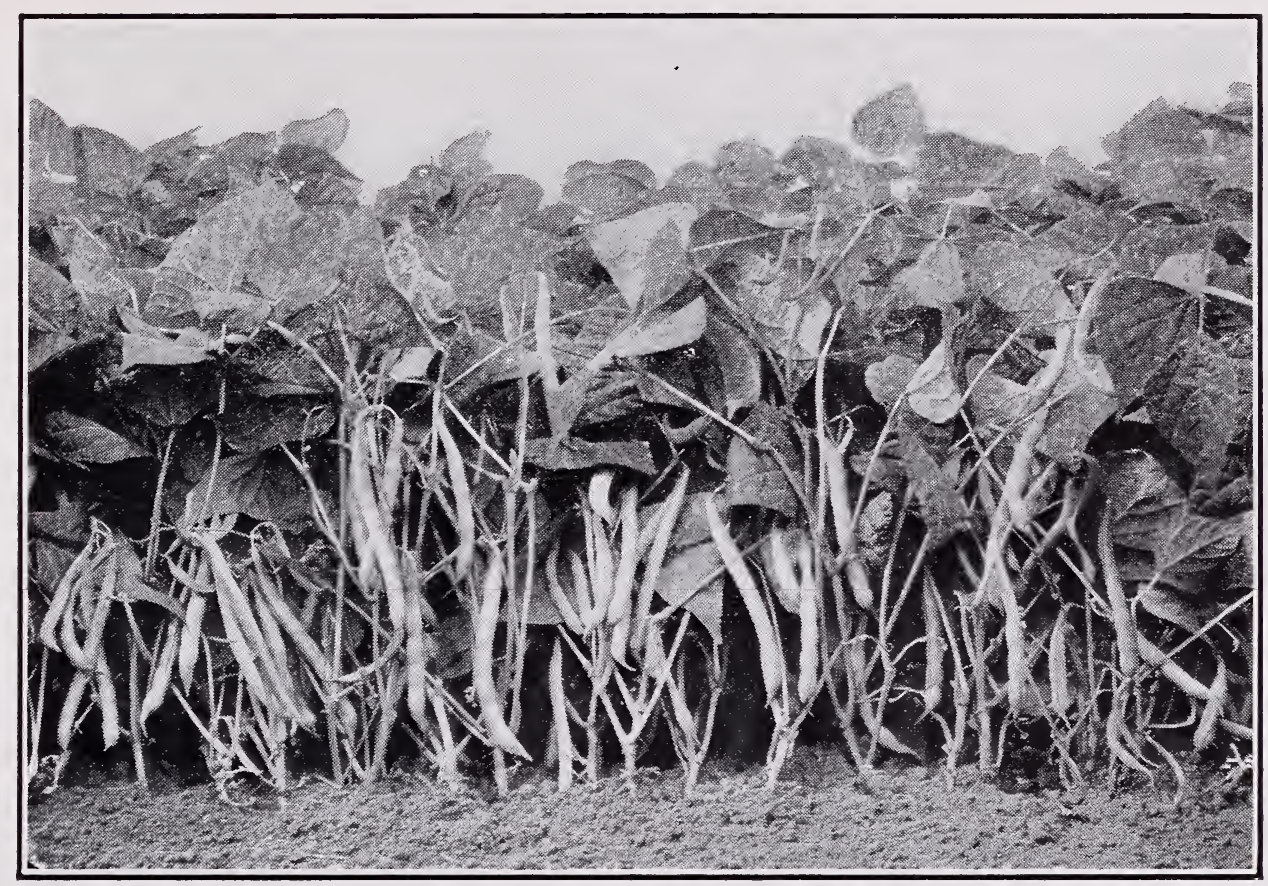

Giant Stringless Green Pod: a well-known Asgrow variety

$\star$ BURPEE'S STRINGLESS GREEN POD, IMPROVED

$\begin{array}{rrr}\begin{array}{r}\text { Length } \\ \text { of pod }\end{array} & \begin{array}{r}\text { Width } \\ \text { of pod }\end{array} & \\ \text { inches } & \text { inches } & \text { Days } \\ \text {.. } 51 / 2 & \frac{7}{16} & 50\end{array}$

Since its origination in 1894 by Calvin $N$. Keeney we have markedly improved this sturdy variety. Plant bushy and productive. Pods nearly round, slightly curved, stringless and fiberless. Seed coffee-brown: 75 per oz.

$\star$ FULL MEASURE

An excellent variety under favorable conditions but less hardy and more susceptible to disease than others. Plant upright and prolific. Pods round, nearly straight, very fleshy, stringless and tender; medium green. Seed reddish brown mottled with buff: 65 per oz.

$\star$ GIANT STRINGLESS GREEN POD

Originated by Calvin N. Keeney; introduced in 1898. Plant large, sturdy, prolific. Pods almost round, meaty, strictly stringless and brittle; without fiber or parchment, with marked indentations between the beans; color medium green. Seed oval, solid yellowish brown: 70 per oz.

$\star$ IDAHO REFUGEE

Resistant to common bean mosaic. Plant of true Refugee type and strongly prolific. Pods longer than regular Refugee, straight, round, silver-green, stringless without fiber; seed purple-blue splashed with buff : 100 per oz. 


\section{BEANS-Continued}

* KEENEY'S STRINGLESS GREEN REFUGEE

\begin{tabular}{|c|c|}
\hline $\begin{array}{l}\text { Length } \\
\text { of pod } \\
\text { inches }\end{array}$ & $\begin{array}{l}\text { Width } \\
\text { of pod } \\
\text { inches }\end{array}$ \\
\hline $5 \mathrm{I} / 4$ & $3 / 8$ \\
\hline
\end{tabular}

Plant large, very spreading, with many tendrils and drooping branches; heavily productive. Pods silvery green, round, stringless, brittle, without fiber. Seed violet-purple, splashed with pale buff: 100 per oz.

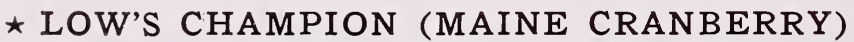

Used in the Eastern States. Holds long in green snap stage. Plant medium, erect, moderately productive. Pods light green, straight, flat, stringless, and of good quality. Seed ox-blood red with white eye: 50 per oz.

\section{RED KIDNEY}

A commercial variety of fine quality for baked beans. Plant large, vigorous, productive. Pods waxy green color, oval flat, stringy, tough and fibrous. Seed reddish brown: 50 per oz.

$\star$ U. S. NO. 5 REFUGEE

Developed and introduced in 1935 by the U. S. Dept. of Agriculture. Highly resistant to common bean mosaic. Plant similar to Keeney's Stringless Green Refugee, pods slightly smaller in diameter and longer; silver-green and devoid of purple splashing, round, straight, stringless and fiberless. Seed of Refugee type but mottled brown: 105 per oz.

\section{WHITE KIDNEY}

A commercial variety of excellent quality for baking. Plant large, erect, bushy, compact, vigorous and productive. Seed long, white, kidney shaped: 50 per oz.

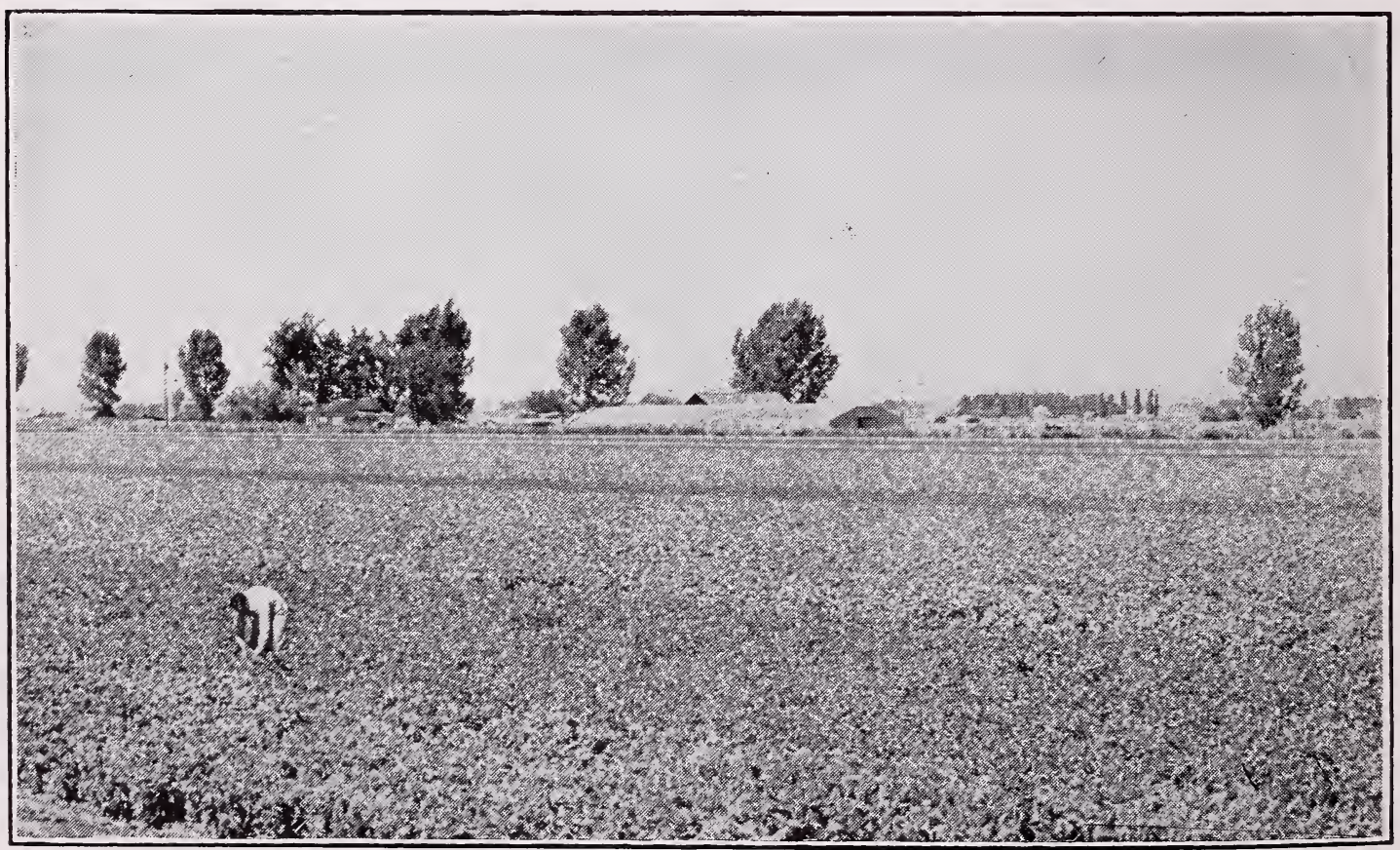

Asgrow Bean-breeding Station, Twin Falls, Idaho 


\section{WAX PODDED: Dwarf or Bush}

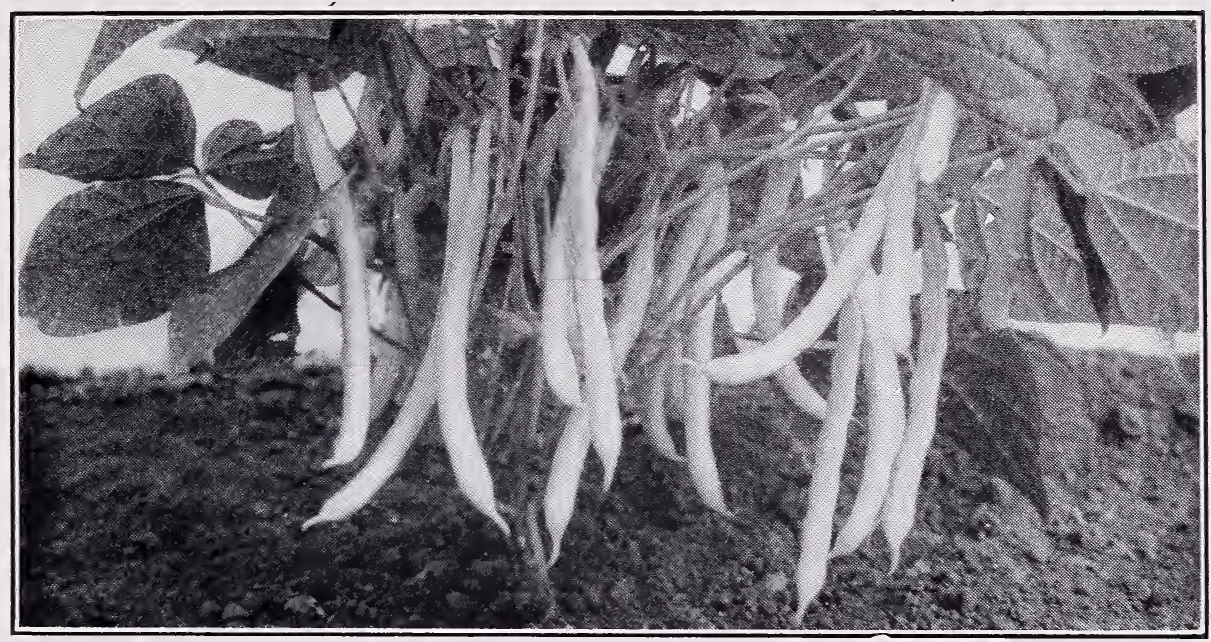

Brittle Wax: also known as Round Pod Kidney Wax

^ BRITTLE WAX (ROUND POD KIDNEY WAX)

Length Width of pod of pod inches inches Days

Originated by Calvin N. Keeney, and introduced in 1900. An outstanding sort for canning and freezing. Plant large, erect, medium green, vigorous and moderately productive. Pods handsome in appearance, medium yellow, round, slightly curved, deeply creasebacked, extremely brittle, fleshy, succulent, absolutely stringless and fiberless; the standard of highest quality. Seed white, kidney shaped, with black eye: 80 per oz.

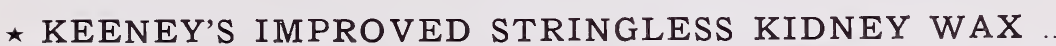

Excellent for canning or quick freezing. Plant large, erect, reasonably productive. Pods oval, light yellow in color, brittle, stringless, fleshy, and of fine flavor. Seed white, kidney shaped with black eye: 75 per oz.

$\star$ PENCIL POD BLACK WAX

Originated by Calvin N. Keeney; introduced in 1900. Primarily a home and market garden variety, but used in some sections for canning and has been frozen very successfully. Plant large, stocky, vigorous and strongly productive. Pods round, slightly curved, fleshy, golden yellow, tender, entirely stringless, without fiber, brittle and of finest quality. Seed oblong, slightly flattened, solid black: 90 per oz. 


\section{POLE BEANS}

$\star$ BLUE LAKE

$\begin{array}{crr}\begin{array}{c}\text { Length } \\ \text { of pod } \\ \text { inches }\end{array} & \begin{array}{r}\text { Width } \\ \text { of pod } \\ \text { inches }\end{array} & \text { Days } \\ 6 & 3 / 8 & 64\end{array}$

Developed from a selection of White Creaseback. Widely used in the West for processing. Pods nearly round, medium green, stringless when young, and of very good canning quality. Seeds 120 per oz.

* BLUE LAKE STRINGLESS

A valuable variety of this increasingly popular canning and freezing type, developed at our Pacific Coast breeding station. The pods differ from those of regular Blue Lake in being stringless at all stages, fully round, somewhat longer and darker in color. Plant vigorous and productive; resistant to common bean mosaic and certain strains of rust. Seed small, oval, white: 100 per oz.

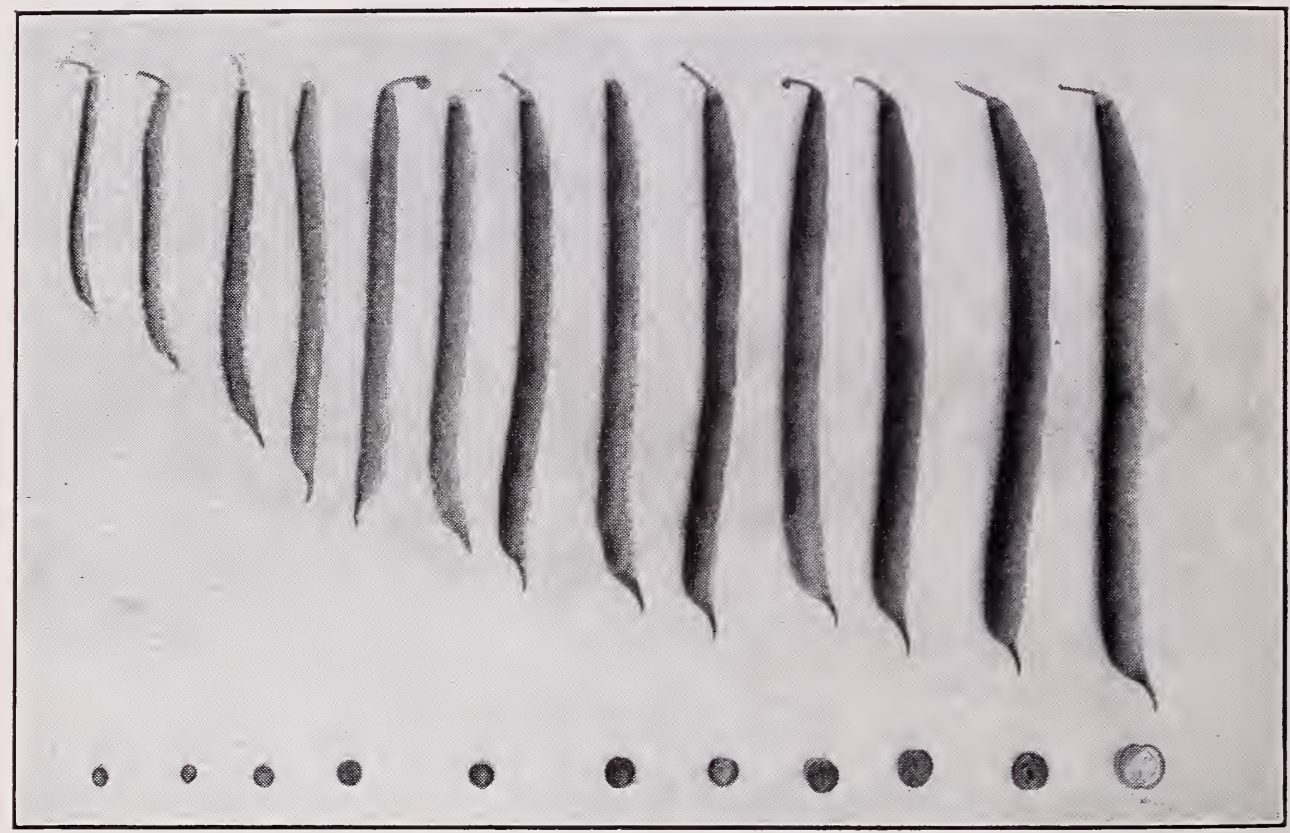

Blue Lake Stringless: Our increasingly popular introduction

DECATUR

All-America Silver Medal for 1942. Plant early, hardy and vigorous, a good climber and with considerable resistance to disease, particularly common bean mosaic and certain forms of rust. Pods nearly round and straight, a lively dark green color, meaty, stringless and of fine quality. Seeds small and ivory white: 100 per oz.

^ KENTUCKY WONDER (OLD HOMESTEAD)

For a frozen pack of fine color and texture. Long pods in clusters, curved and indented; plump and almost round, meaty, brittle, fiberless with a distinctive and pleasing flavor. Seed buff brown: 80 per oz.

KENTUCKY WONDER WHITE, Round-Podded Asgrow Strain Vigorous plants, 5-6 ft. tall. Pods nearly straight, round, very meaty and stringless at all stages. Shows resistance to rust. Seed medium oval, white: 75 per oz.

$\star$ Suitable for quick freezing. 


\section{LIMA BEANS: Dwarf or Bush}

$\star$ BABY POTATO

All-America Silver Medal for 1940 . Originally selected by

Prof. W. A. Huelsen, University of Illinois; developed and introduced by Associated Seed Growers, Inc. The beans are small but thick, of bright green color when fresh, and similar in flavor to Fordhook. Seeds white: 65 per oz.

\section{EARLY BABY POTATO}

Similar to Baby Potato but a week earlier and with slightly lighter pods. Developed by us for areas of shorter season or to follow an earlier crop.

\section{BABY FORDHOOK}

Developed by Dr. Roy Magruder at the Ohio Experiment Station. Pods resemble Henderson's Bush but are smaller and thicker, tightly filled with 3-4 small plump seeds of high quality, deep green early, lightening in color later. Seed light cream: 65 per oz.

$\star$ CLARK'S BUSH

Exclusively a product of the Asgrow breeding program and introduced in 1940, this is a variety of Henderson's Bush type, resembling the original in plant and pod but distinguished by its freedom from white beans at all harvesting stages. Of great value to processors through the reduction of labor on the picking belt. Dry seeds mainly pale green: 70 per oz.

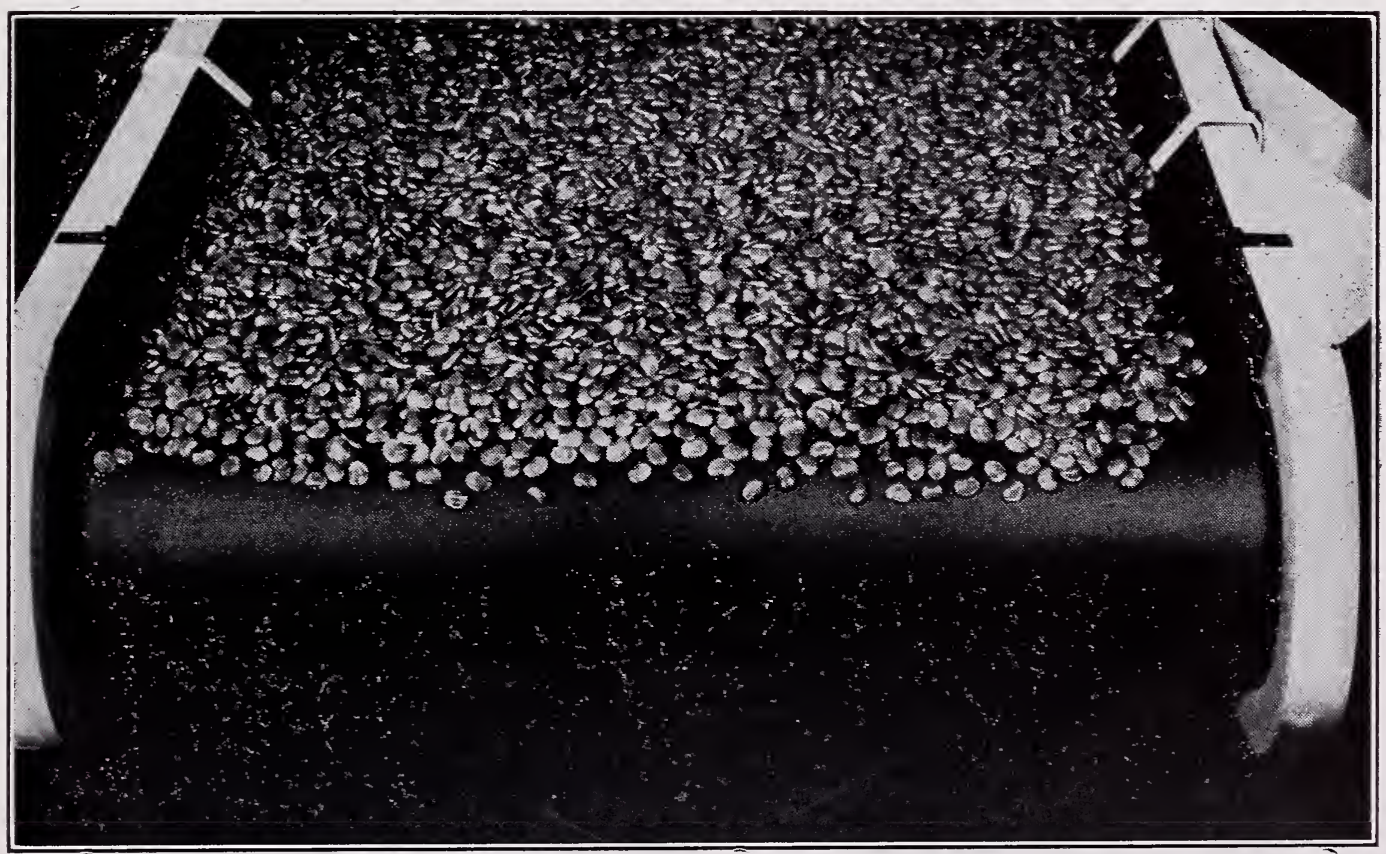

Clark's Bush: Introduced after 17 years of Asgrow breeding and testing 


\section{LIMA BEANS-Continued}

* CONCENTRATED FORDHOOK

$\begin{array}{ll}\text { Length } & \text { Width } \\ \text { of pod } & \text { of pod } \\ \text { inches inches Days } & \end{array}$

$33 / 4 \quad 1$

Ty $U$. Department of A seeded bush type. Plant medium large, with a heavy early yield. Pods curved, uniform in size, shape and fill; usually contain 3, sometimes 4 large, broad green beans of excellent quality. Dry beans greenish cream: 25 per oz.

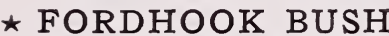

Large seeded potato lima type. Plant large, very sensitive to environment, highly productive. Pods straight, long, with thick fibrous walls; contain 3-4 large, thick-oval beans of excellent quality. Dry beans white with tinge of green: 20 per oz.

$\star$ FORDHOOK 242

Developed by the U. S. Department of Agriculture. Plant as tall as regular Fordhook but with greater spreading habit. Pods slightly curved, with thinner walls than Fordhook, containing 3-4 light green beans of same excellent quality. Produces heavily under high temperature conditions. Dry beans greenish cream and light green: 30 per oz.

$\star$ HENDERSON'S BUSH

Sometimes called Baby Lima, and known in the South as a for increased yielding power and concentration in season. Plant small, dark green, erect, bushy, very early. Pods flat, containing 3-4 flattish, small oval beans. Dry beans creamy white: 70 per oz.

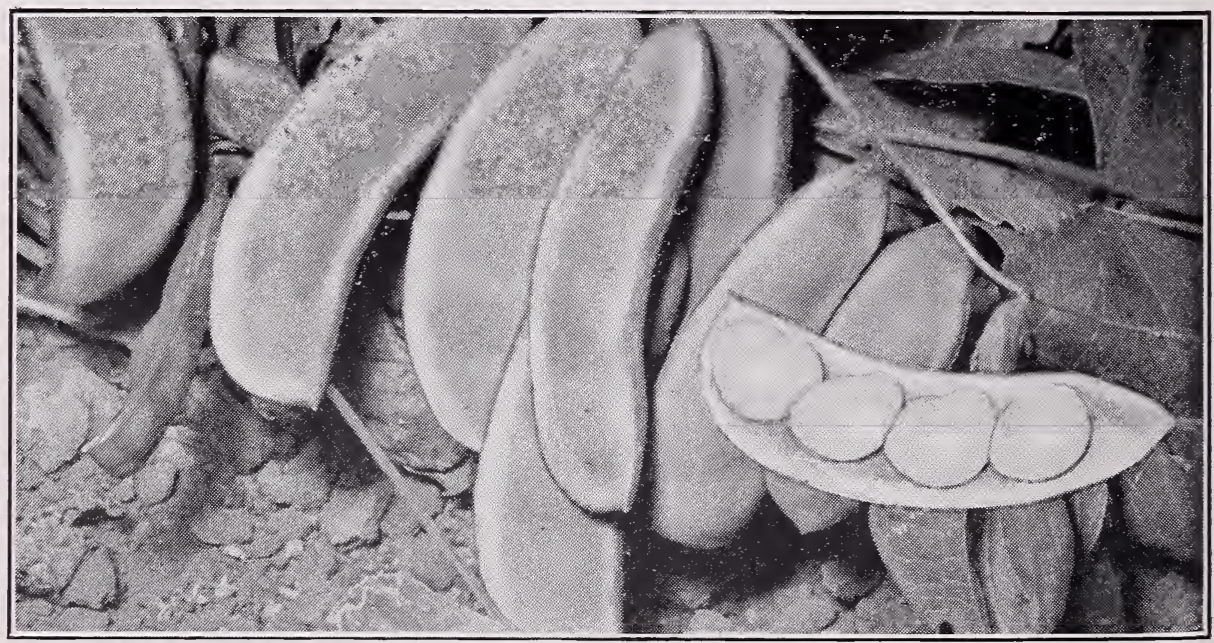

Concentrated Fordhook: a marked improvement

\section{POLE LIMA BEANS}

CHALLENGER, IMPROVED (Fordhook Pole: Burpee's Best) A potato lima, similar in pod and seed to Fordhook Bush Lima. Plant vigorous, hardy, good climber, very productive. 


\section{BEET}

In the production of the leading varieties of beet we have bred pedigreed strains for many years. Earliness, evenness of maturity, depth of color and small tap roots are features of these stocks grown from mother beets selected with discriminating care.

The number of days shows the time required under average conditions in the North from planting of seed to the production of roots about $13 / 4^{\prime \prime}$ in diameter.

Days

ASGROW CANNER

All-America Silver Medal 1936. Bred by us especially to meet canners' requirements; notable for its very deep, attractive color and superior quality. Tops strong and erect, medium tall, about 14 inches, green with red ribs. Roots smooth, globe-shaped, with small neck; dark maroon-red. Flesh lively deep ox-blood red; exceptionally vivid and attractive when cut; richly colored juice. Recommended for small whole, diced or sliced beets

\section{ASGROW WONDER}

All-America Gold Medal 1934; an award confirmed since then by its popularity with growers. A pedigreed stock, the result of many years of breeding; unsurpassed in earliness, uniformity, and in general dependability. Tops large, distinctively green. Roots round when young, semi-globular later, deep red, smooth, with small neck and tap root. Flesh deep dark red, tender, and of excellent quality.

\section{DETROIT DARK RED}

The Asgrow pure-bred strain of this standard variety is of excellent quality. Tops medium, dark green tinged with red. Roots globular, smooth, uniform, attractive, with small tap root. Color deep ox-blood red. Flesh dark red. Fine quality, sweet and tender.

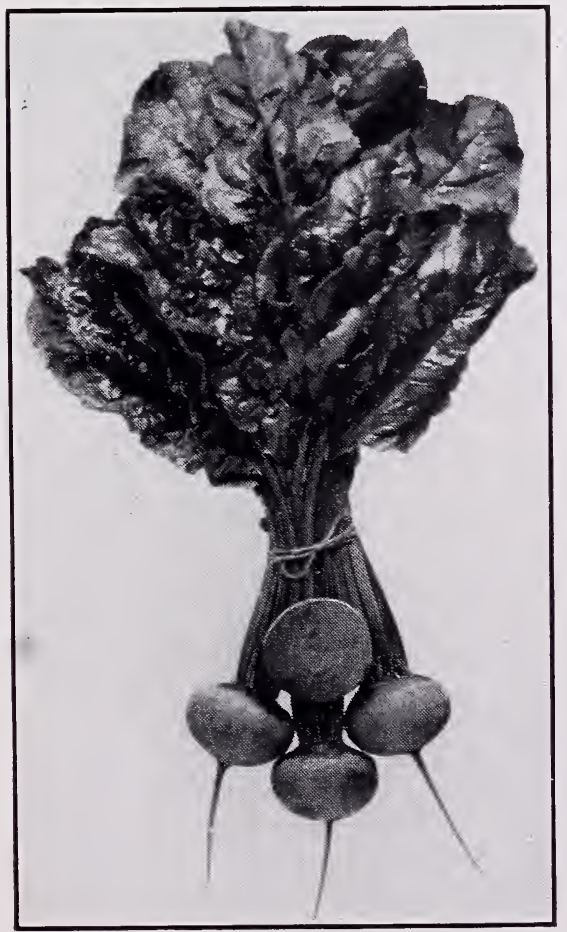

Asgrow Wonder

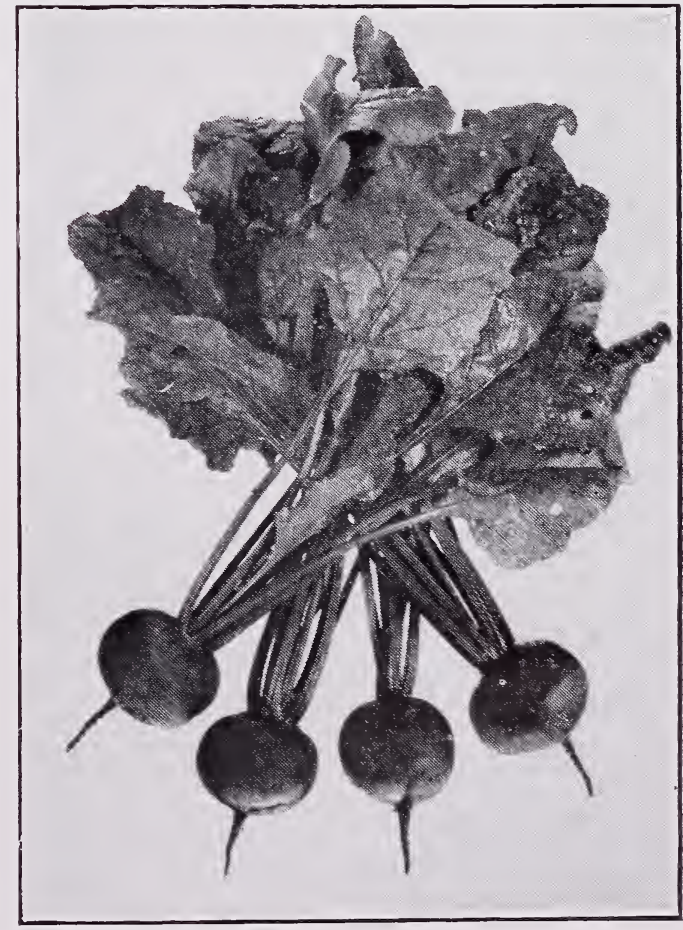

Asgrow Canner 


\section{OHIO CANNER}

Days

Developed by Dr. Roy Magruder at the Ohio Agricultural Experiment Station, and awarded the All-America Silver Medal for 1933. Tops medium small, erect. Roots flattened globe in shape, smooth, ox-blood red; flesh dark red with slightly lighter zones, sweet and tender.

PERFECTED DETROIT

Tops tall and erect, green with some red. Roots globular, slightly flattened, medium smooth, deep red; flesh dark red and practically free from zoning; of good quality and very suitable for canners.

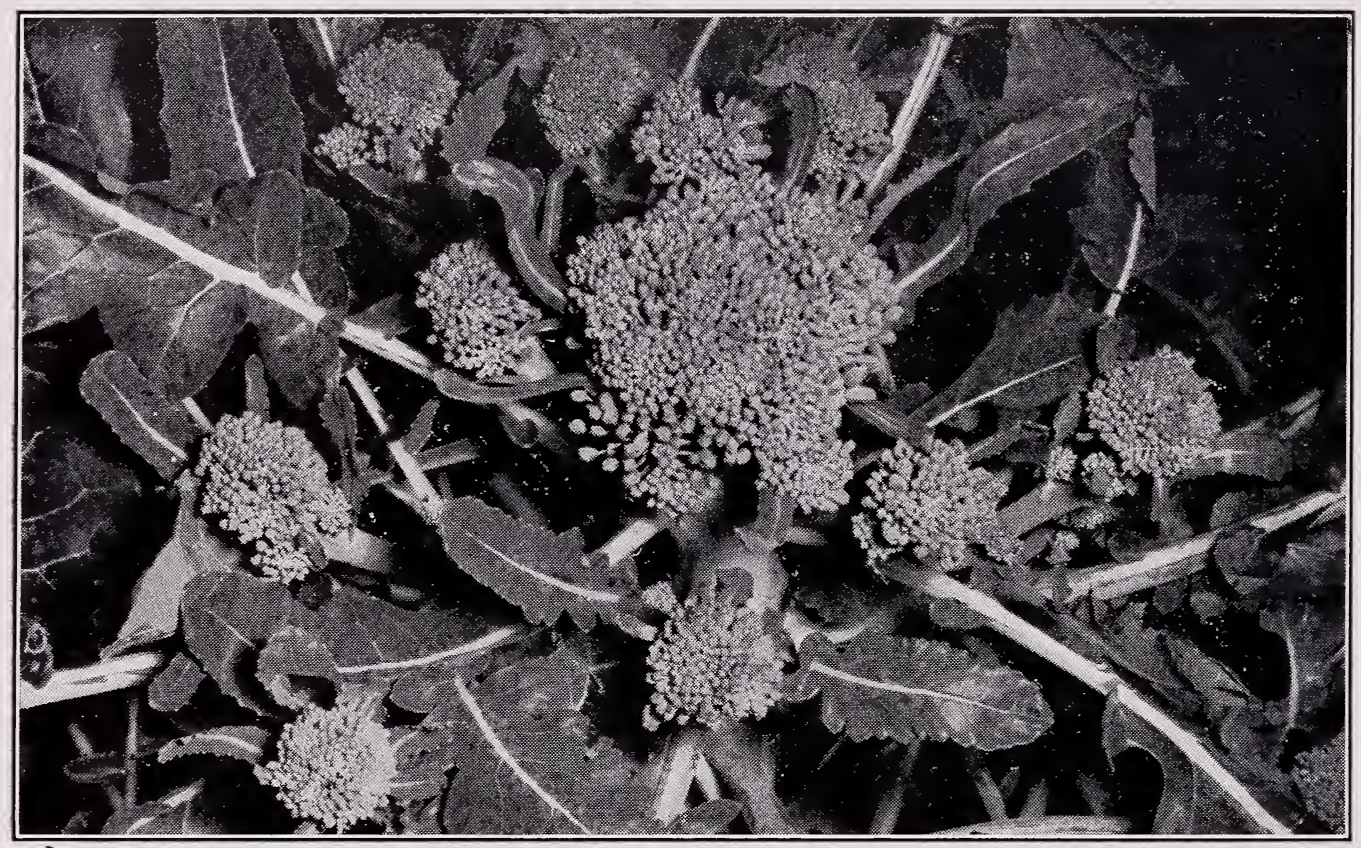

Freezers' Sprouting Green: especially suited to the frozen pack

\section{BROCCOLI}

* CALABRESE, GREEN, EARLY

The leading variety for canning and quick freezing. The tall branching plant forms a compact head of bluish green flower buds resembling a head of cauliflower. After the main head has been removed, side shoots with small heads continue to develop.

$\star$ GREEN, MEDIUM

Very similar to our early strain, above, but about a month later in maturity.

* FREEZERS' SPROUTING GREEN

A new variety of true sprouting type developed at our Pacific Coast breeding station. Bred especially to meet a need of the quick-freezing industry. Many individual sprouts with small heads are formed, but are not concentrated into a central head, thus providing more suitable freezing material and facilitating picking and packing.

\section{BRUSSELS SPROUTS}

$\star$ HALF-DWARF IMPROVED

Plants 22"-26" tall; stems thickly set, with firm cabbage-like balls of $1 \mathrm{I} / 2$ " diameter, maturing successively. 


\section{CABBAGE}

Our cabbage seed is produced largely in the Puget Sound section at our western Washington production branch from seed stocks of highest quality. Each year the various varieties are checked at our Eastern breeding station, Milford, Conn., to guard the vital factors of earliness, evenness of maturity and uniformity.

Varieties marked y.r. have been developed, mainly at the University of Wisconsin, for resistance to the cabbage-yellows disease. It is recommended that only these varieties be planted in infested areas.

The column of Days gives relative period to maturity from setting out plants.

Resembles standard strains of All Head. Firm heads, flat to slightly rounded at top. Uniform and of fine quality for early sauerkraut.

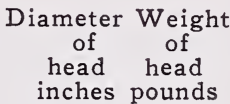

96

\section{COPENHAGEN MARKET}

$6 \mathrm{I} / 2 \quad 3 \mathrm{I} / 2$

Dependably early and uniform, used largely for early kraut.

Outer leaves few and of gray-green color, short stem; heads round, solid, and of superior quality. An excellent short season type.

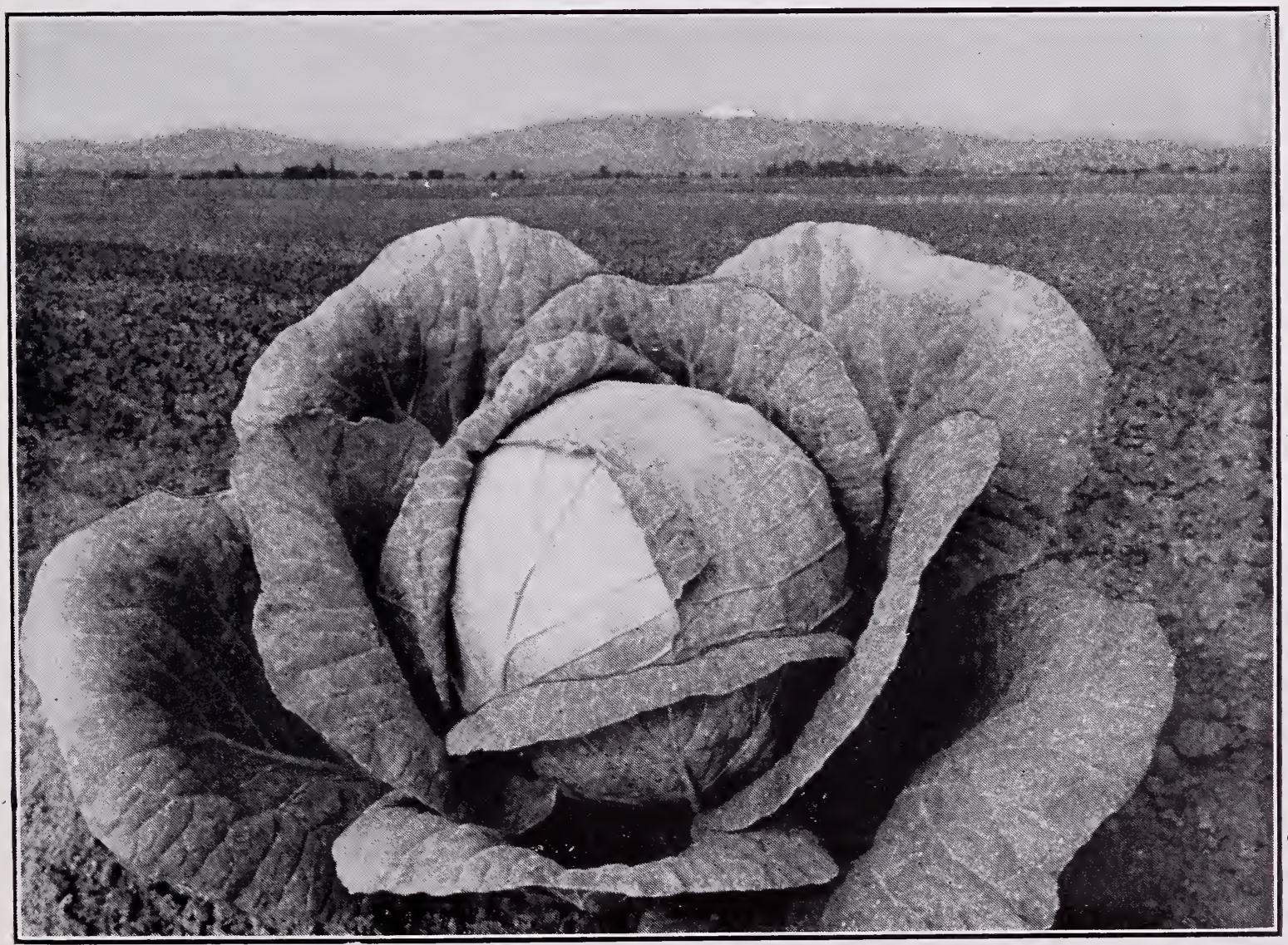

Copenhagen Market. In the background is Mt. Hood 
DANISH BALL HEAD (HOLLANDER)

\begin{tabular}{|c|c|c|}
\hline $\begin{array}{c}\text { Diameter } \\
\text { of } \\
\text { head } \\
\text { inches }\end{array}$ & $\begin{array}{l}\text { Weight } \\
\text { of } \\
\text { head } \\
\text { pounds }\end{array}$ & Days \\
\hline $7 \mathrm{I} / 2$ & $61 / 2$ & 103 \\
\hline
\end{tabular}

Most widely used and best type of late cabbage for kraut or storage. Plant fairly large, sturdy, with short stem; outer leaves medium. Heads deep round, very hard; interior decidedly compact, leaves composing head smooth and closely arranged. Texture tender, crisp; flavor good; ideal for high quality kraut.

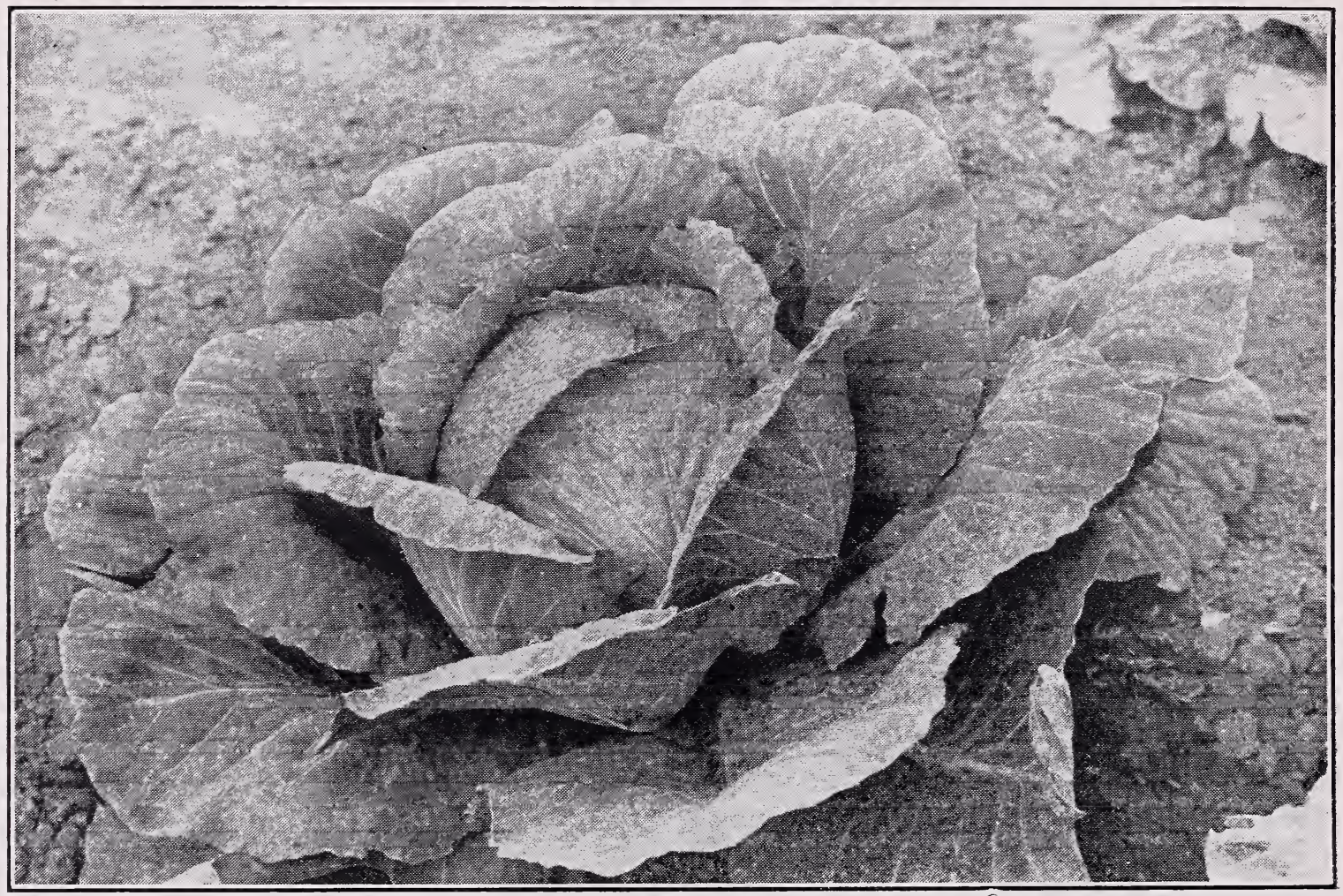

Danish Ball Head: A favorite variety for kraut

GLORY OF ENKHUIZEN

An attractive second-early variety, used largely for kraut. Heads large, round, solid, with few outer gray-green leaves; of excellent quality.

GOLDEN ACRE

An extra early Copenhagen type with small, round, quite solid heads, maturing with Jersey Wakefield. Plant dwarf, with few outer leaves.

GREEN ACRE

An attractive strain of Golden Acre. The type and general characteristics are the same, but Green Acre holds its green color longer.

IMPROVED GLOBE, y.r.

An improved resistant strain of Glory of Enkhuizen. Large, round, solid heads. 
MARION MARKET, y.r.

A development from Copenhagen Market but with slightly larger, later maturing, round, firm heads; leaves more bluegreen. Good for kraut or market.

PENN STATE BALL HEAD

Heads extremely hard, flattened globe, 6"-7" deep. Desirable $6 \mathrm{I} / 2 \quad 4$ for winter storage and for kraut in districts free of the cabbage-yellows disease.

\section{PREMIUM LATE FLAT DUTCH}

Deservedly popular for its heavy yield. Heads very large, flat, and solid; leaves light gray-green; 61/2"-7" deep; of high quality.

RED DANISH (Red Dutch)

A superior strain of Red Rock developed by careful selection for uniformity and quality. Heads round, hard and heavy, deep colored throughout. A good pickler.

RESISTANT GOLDEN ACRE (RESISTANT DETROIT), y.r. ... A Golden Acre type from Denmark into which yellows-resistance has been bred. Medium round heads.

WISCONSIN BALL HEAD, y.r.

Heads very hard, smaller but more uniform and smoother than Wisconsin Hollander, short stem, blue-green leaves.

WISCONSIN HOLLANDER, y.r.

Selected from Danish Ball Head, the first yellows-resistant variety of the series developed by Prof. L. R. Jones and Dr. J. C. Walker at the University of Wisconsin; now greatly improved in quality and resistance. Heads round, becoming slightly flattened, color blue-green. A heavy cropper.

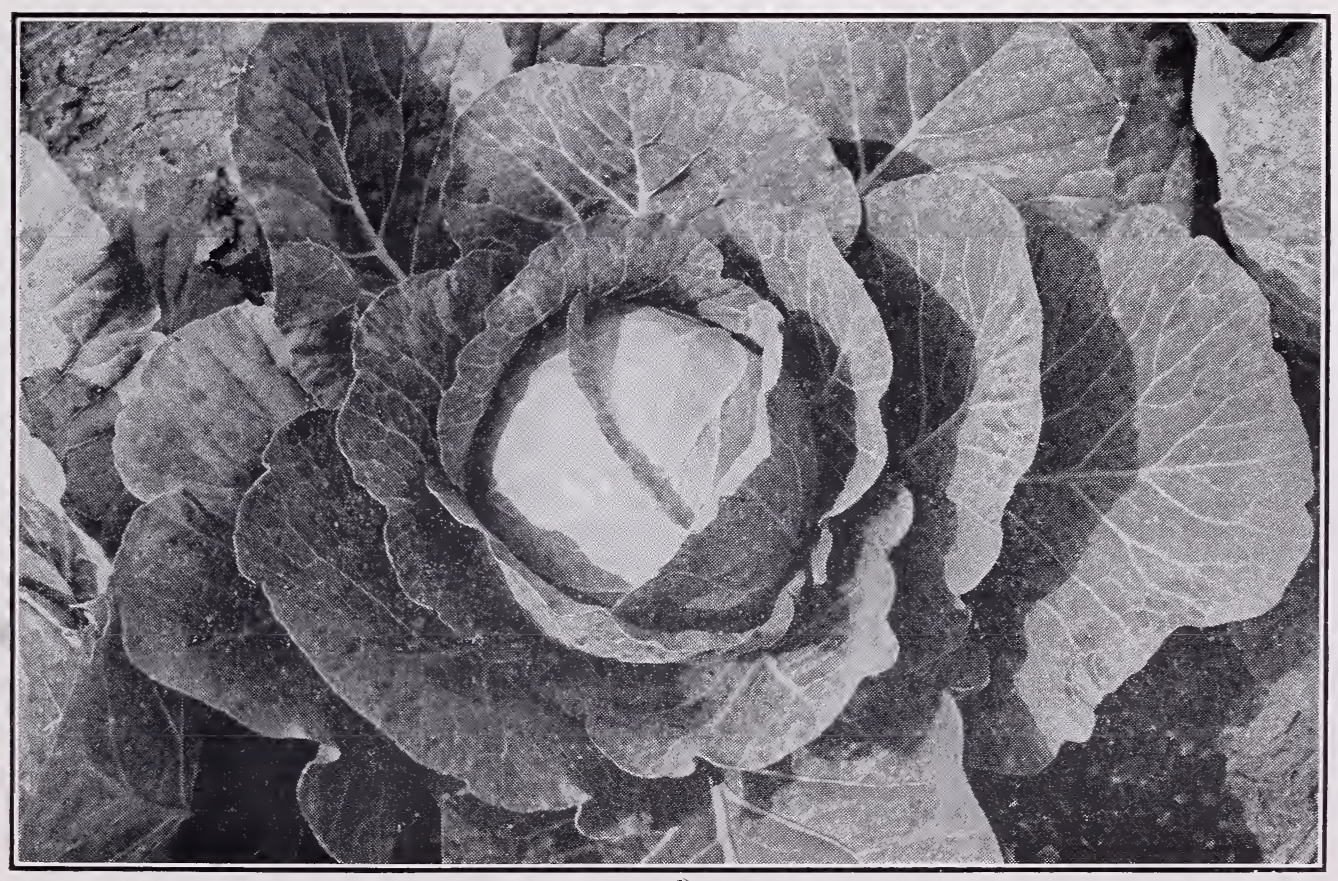

Marion Market: A yellows-resistant type 


\section{CARROT}

Planting stocks are developed at our breeding stations from individual progenies which have met the most exacting specifications in performance. Smoothness and shapeliness of roots with depth of exterior and interior color are vital factors in rating parent lines.

In giving the number of days for the development of roots, we have used the average of readings for a period of years. These will vary considerably in different locations.

* CHANTENAY, IMPROVED LONG

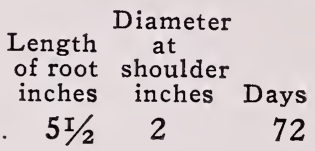

A well known and popular all-purpose variety; desirable for canners in packing diced carrots; a good cropper. Roots deep orange, smooth, tapered, stump-rooted; flesh deep orange.

$\star$ CHANTENAY, RED CORE

Developed and introduced by C. C. Morse \& Co. A desirable Chantenay with good interior color; excellent for dicing and in frozen pack of peas and carrot. Roots somewhat shorter than Improved Chantenay; flesh reddish orange, with indistinct core of nearly the same color as the surrounding flesh.

$\star$ NANCY

Developed at our Pacific Coast breeding station. The roots are thicker at the shoulder than Nantes, tapering slightly to a blunt end, coreless, sweet, and of very high quality, with stronger tops.

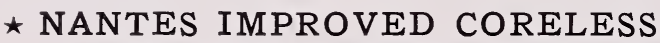

Excellent for forcing for cannirig and for quick freezing whole carrots. Tops very small. Roots bright orange, cylindrical, blunt ended. Flesh reddish orange, crisp, tender, and of very delicate flavor; practically coreless.

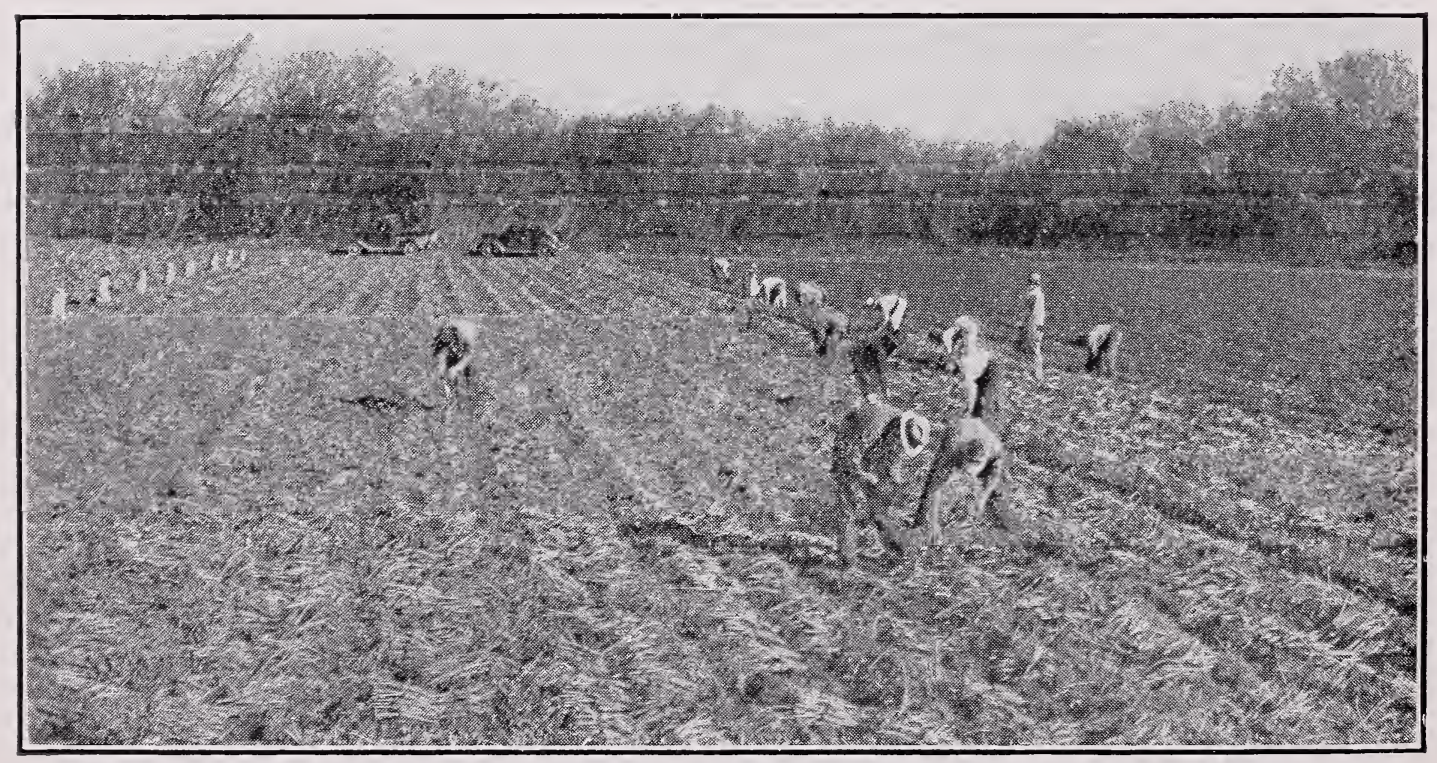

Roots are carefully selected for transplanting to seed-production fields 


\section{CAULIFLOWER}

$\star$ DANISH GIANT (Dry Weather)

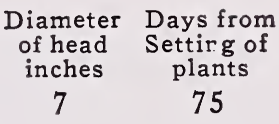

Well adapted to dry weather conditions; later than Early Snowball and of larger growth. Heads creamy white, and of excellent quality.

$\star$ EARLY SNOWBALL

The best and most widely used early variety; good for use in packing mixed pickles. Plants dwarf, with short pale green leaves. Heads medium, firm, compact, solid, pure white, and of finest quality; a dependable header. Well adapted to freezing.

$\star$ SNOWDRIFT

Plant of medium height with upstanding, medium green outer leaves. Head slightly larger than Snowball, firm, solid, very white, well protected by inner folding leaves; curd has fine texture and is free from small protruding leaves.

$\star$ SUPER-SNOWBALL

A highly desirable main crop variety, also used for early planting. Starts heading early and uniformly. Heads medium large, compact, very white; much used in the fresh vegetable industry and has given satisfactory results in Eastern freezing.

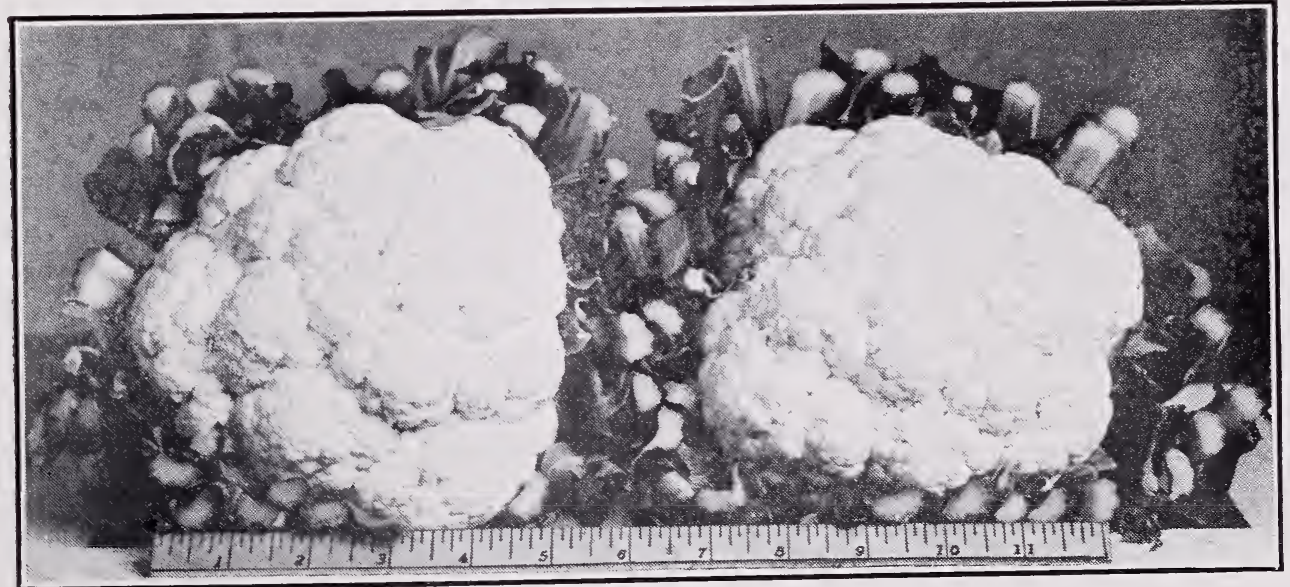

Snowdrift: a well known and reliable variety

\section{CELERY}

\section{EASY BLANCHING (SANFORD SUPERB)}

An excellent second early green variety. Vigorous and compact in habit of growth, it blanches readily to attractive white, and is a good keeper. Stalks slightly taller than Dwarf Golden Self Blanching; thick, solid; of good flavor.

UTAH (Golden Crisp)

A very desirable green type. Plant stocky, full hearted and compact; blanches readily. Stems thick, solid, medium broad and full rounded; of nutty flavor and fine quality. 


\section{SWEET CORN}

Sweet corn has been a leader with us for over eighty years during which time we have originated many well-known varieties. Our production program includes the maintenance of excellent strains of standard sorts and the development of new, superior lines.

Through the use of more recent breeding methods for the improvement of sweet corn varieties, we have developed, through nearly twenty years of controlled pollination, many inbred lines of high merit. The crossing of these produces hybrids of outstanding vigor, uniformity and productivity. Disease resistance is also a vital factor and we can now furnish various hybrids that are highly resistant to Stewart's disease or bacterial wilt.

The number of days indicated for each variety represents average trial row readings for many years at our Eastern breeding station, Milford, Conn.

In some sections maturity dates will naturally be different.

Varieties marked (y) have yellow kernels; those marked (w) have white.

\section{HYBRIDS}

$A$ hybrid is the first generation of a cross between strains of different parentage and involving one or more inbred lines of corn or their combinations.

Ohio State Law.

\section{ALLEGHENY (y)}

$\begin{array}{crr}\begin{array}{c}\text { Height } \\ \text { of stalk } \\ \text { feet }\end{array} & \begin{array}{r}\text { Length } \\ \text { of ear } \\ \text { inches }\end{array} & \text { Days } \\ \text {.. } 7 \mathrm{I} / 2 & 7 \mathrm{I} / 2 & 89\end{array}$

All-America Bronze Medal, 1941. An exclusive Asgrow hybrid. Tall, vignrous plant, highly resistant to Stewart's disease (bacterial wilt) and a heavy yielder. Ears 2" diameter, mainly 18-22 rowed, well filled to tips with very narrow, long kernels of medium yellow color.

COGENT HYBRID $19 \times 24$ (w)

A Country Gentleman hybrid variety of our breeding and exclusive production. Has a somewhat thicker ear and larger kernels than Shoepeg Hybrid $19 \times 9$. Well adapted for areas of heavy, rich soil in the Eastern States. Stalk erect, with good foliage, and prolific. Ears 17/8" diameter, long, slightly tapered, well filled at tips.

\section{COUNTRY GENTLEMAN HYBRID (I11.) $8 \times 6$ (w)}

An extremely drought-resistant variety originated by Prof. W. A. Huelsen of the University of Illinois. Ears 17/8" diameter. Well adapted to the Midwest and especially for the needs of canners. Notable for its high percentage cut-off.

COUNTRY GENTLEMAN HYBRID (I11.) $5 \times 10$ (w)

Also originated by Prof. Huelsen and admirably adapted to Midwestern conditions. Ears 2" diameter. A prolific variety, giving high yields except in extreme drought when it is easily outclassed by Hybrid $8 \times 6$.

An exclusive Asgrow hybrid, having long cylindrical ears slightly tapered, 15/8" diameter, mainly 12-14 rowed. Plants wilt resistant, vigorous, and relatively resistant to drought. In comparison with Golden Cross Bantam, this hybrid produces a plant 6" taller, bearing ears 4" higher on the stalk, maturing 3-4 days later. Widely adapted. 
$\star$ GOLDEN CROSS BANTAM (y)

68

Originally developed by Glenn M. Smith and introduced jointly

by the U. S. Department of Agriculture and Purdue University. Extremely uniform in plant and ear characteristics and in maturity. Highly resistant to Stewart's disease. Now the most extensively used hybrid. Widely adapted to canner's use and excellent for quick freezing. Stalk sturdy and upright. Ears 10-14 rowed, 13/4" diameter, cylindrical. Kernels rich in color, medium in width and depth.

$\star$ GOLDEN HYBRID NO. 2439 (y)

An exclusive Asgrow development from crossing inbred lines Asgrow 24 x P39. Exceptionally valuable to canners and freezers. Plant tall, vigorous, uniform, comparatively free from suckers; leaves wide, dark green and numerous. Ears 17/8" diameter, cylindrical, 14-16 rowed, with long husks affording considerable resistance to ear worm. Kernels lustrous yellow, medium-narrow and deep, with tender hull; sweet and of excellent quality. Highly resistant to Stewart's disease.

$\star$ IOANA (y)

Originated by Dr. E. S. Haber of Iowa State College, commercially developed and entered by us in the All-America Selections trials for 1939 when it was awarded a Bronze Medal. An attractive and productive variety, highly resistant to wilt. Plants tall and sturdy, with broad and numerous leaves. Ears 71/2"-8" long, 17/8" diameter, 12-14 rowed, cylindrical; well filled with medium-narrow, light yellow kernels, fairly resistant to ear worms. 


\section{CORN-Continued}

$\begin{array}{ccr}\begin{array}{c}\text { Height } \\ \text { of stalk } \\ \text { feet }\end{array} & \begin{array}{c}\text { Length } \\ \text { of ear } \\ \text { inches }\end{array} & \text { Days } \\ 6 & 61 / 2 & 80\end{array}$

$\star$ KENNEBEC (y)

Developed at our Eastern breeding station to meet the need for a hybrid of Golden Cross Bantam type but about a week earlier. Ears a little shorter than Golden Cross Bantam but otherwise very similar, including kernel type and husk coverage ; $13 / 4$ " in diameter, $12-14$ rowed, cylindrical. A very promising hybrid for its intended purpose.

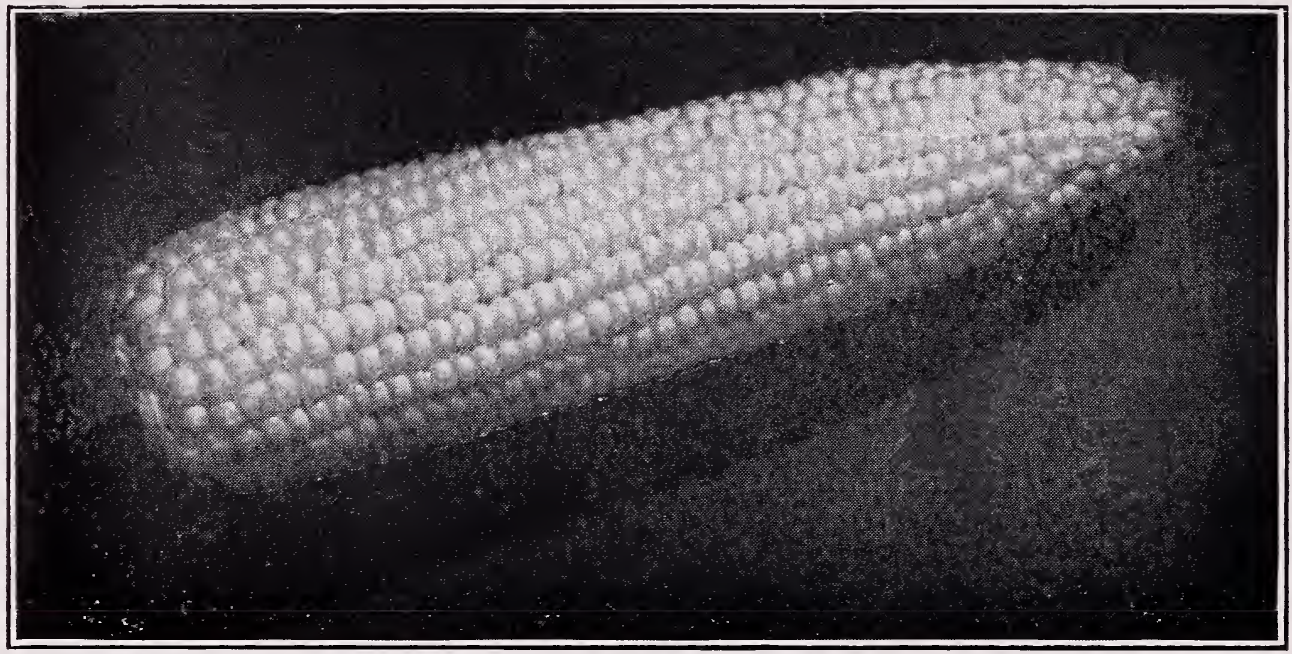

Narrow Grain Hybrid $14 \times 11$ : an excellent late type

NARROW GRAIN HYBRID (Ill.) $14 \times 11$ (w)

A hybrid variety developed primarily to provide canners with a late white type of heavy yield and high quality in shape and texture of kernels. Stalks tall and strong; ears large, 2" diameter, and well filled with 18-22 rows of narrow, deep kernels.

* NARROW GRAIN HYBRID 26 x 15 (w)

An exclusive product of Asgrow inbred lines. Very uniform and highly desirable for canning and freezing. Stalks sturdy, upright with no suckers; leaves wide, dark green. Ears 2" diameter, uniformly tapered, with $18-22$ rows. Kernels narrow, deep, tender.

OTO (y)

An exclusive Asgrow development. A long eared, wilt resistant hybrid with cylindrical $8-12$ rowed ears, $11 / 2$ " diameter, of attractive appearance and with excellent husk coverage. Plants very vigorous, relatively resistant to drought. Oto produces a plant 14" taller than Golden Cross Bantam, bearing ears 8" higher on the stalk, maturing about 2 days later.

PONTIAC (w)

An exclusive Asgrow hybrid. High yielding wilt-resistant and well adapted to Midwestern as well as Eastern conditions. Stalks strong, with ears relatively free of flag leaves. Ears 2" diameter, trim and well filled with 16-20 straight rows of very white kernels, narrow and of good depth. Husks long, affording considerable resistance to ear worm. 
$\star \operatorname{SACHEM}(y)$

An exclusive Asgrow hybrid, produced from our own inbred

lines as an early companion to Golden Cross Bantam, and thus

$6 \quad 73 / 4$ affording a longer season of this most desirable type. Plants vigorous and very resistant to bacterial wilt. Ears $15 / 8$ " diameter, long, trim, and well filled to tips with $10-14$ rows of medium-deep, bright yellow kernels. A very attractive and promising variety for canning and freezing.

SHOEPEG HYBRID $19 \times 9$ (w)

Exclusively an Asgrow production from our own inbred lines. Particularly suitable as a fine-kerneled corn for canners in Eastern areas only. Stalk sturdy, upright with ears $3 \mathrm{I} / 2-4 \mathrm{ft}$. from ground. Ears long, cylindrical, $15 / 8$ " diameter, well filled at tips. Kernels very fine and deep, tender and of excellent quality.

STOWELL'S EVERGREEN HYBRID 14 x 5 (w)

Our development from crossing inbred evergreen lines Asgrow 14 x Asgrow 5. All-America Bronze Medal for 1934. Highly valuable to canners, especially in the East. Stalks sturdy with close growing upright ears, $4 \mathrm{ft}$. from ground; foliage medium green. Ears 2" diameter, very slightly tapered, uniform, with 16-18 rows. Kernels very white, medium-wide, deep; medium cob.

$\star$ TENDERGOLD (TOP CROSS SUNSHINE) (y)

A good variety maturing ahead of Golden Cross Bantam. Stalk sturdy with good foliage; highly resistant to Stewart's disease. Ear nearly cylindrical, 13/4" diameter, 12-16 rowed, kernels medium in width and depth, golden yellow, tender and of good quality. Desirable for canners and freezers in northerly sections.

$\star$ TOP CROSS MAINE BANTAM (Maine Bantam P39) (y) ........
Our development; has proven highly successful for canners and Our development; has proven highly successful for canners and
freezers in short season areas. Stalk sturdy with deep green foliage; ear slightly shorter than Golden Cross Bantam, 13/4" diameter, very slightly tapered with $12-16$ rows; kernels medium-narrow and golden yellow, tender and of excellent flavor. Highly resistant to Stewart's disease.

WINNEBAGO (w)

A hybrid of Country Gentleman type developed at our Midwestern breeding station particularly for canners in that area. The plant is tall and sturdy, with strong root system and very resistant to drought. Has relatively few suckers. The ears are medium long, 2" diameter, with deep, narrow, shoepeg kernels, giving a high percentage of cut-off.

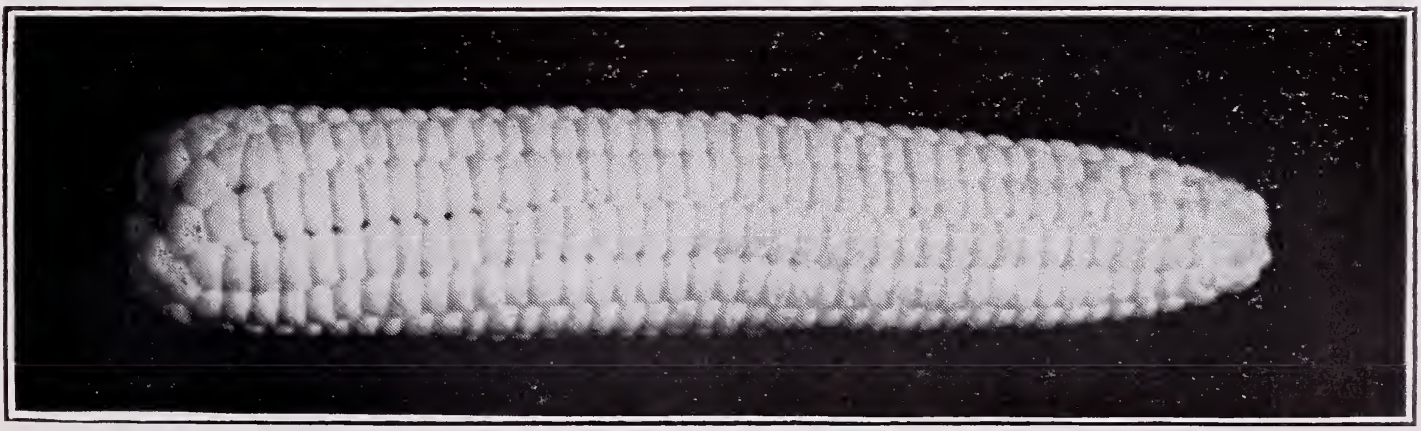

Oto: a new Asgrow hybrid, long and slender

* Suitable for quick freezing. 
U
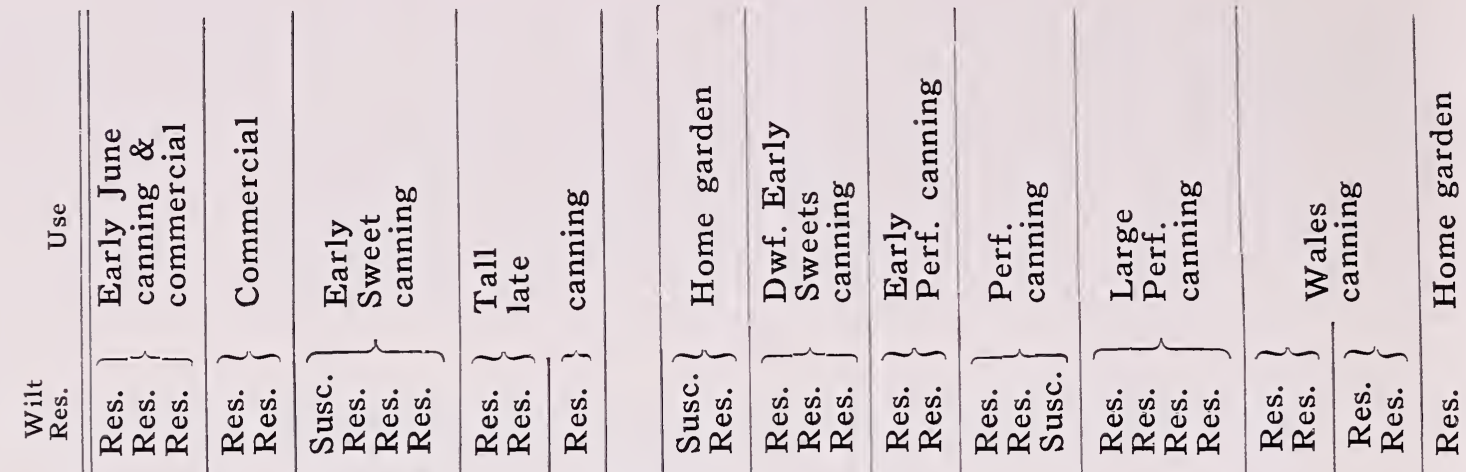

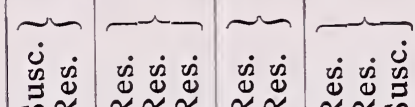

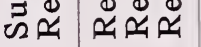

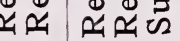

$\dot{v} \dot{\delta} \dot{\delta} \dot{\delta}$

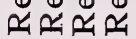
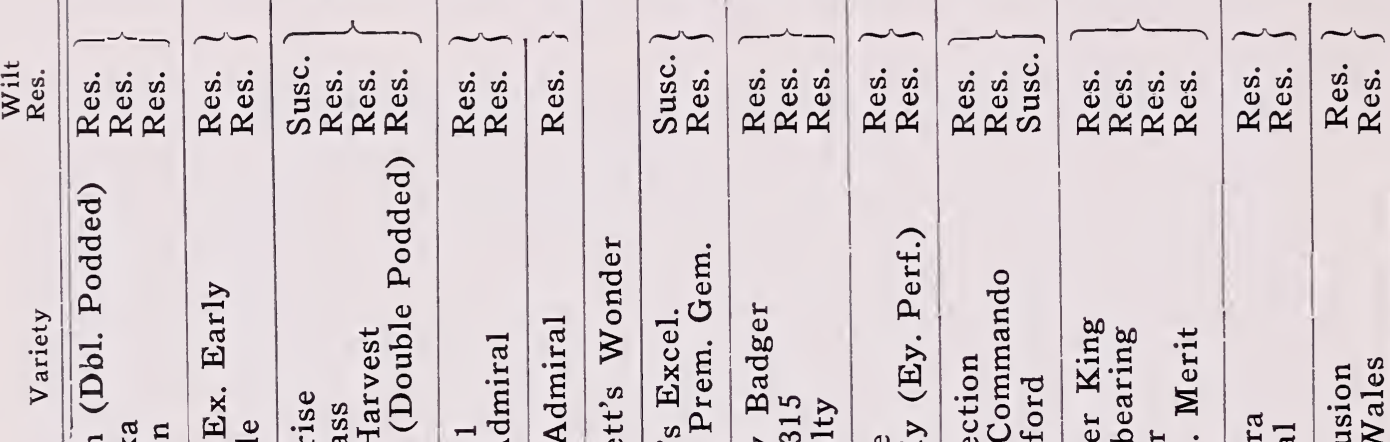

总

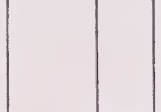

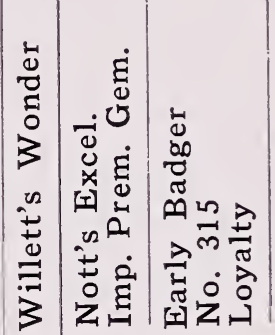

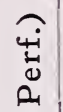

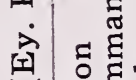

ปี

范定

玟。

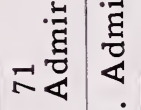

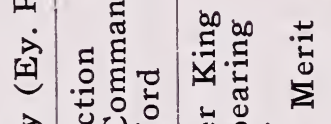

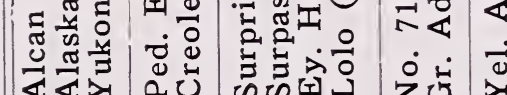

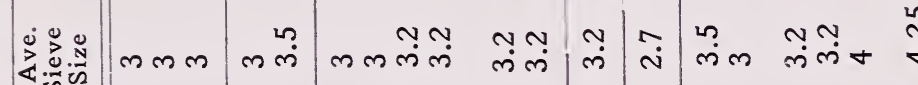

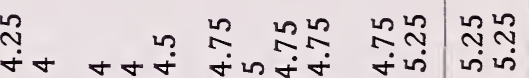

is is

>

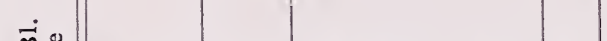

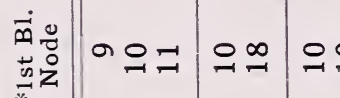

$\stackrel{20}{\sim}$

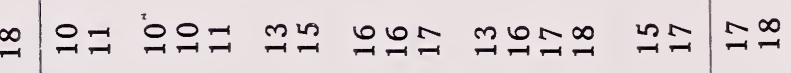

苞

ن

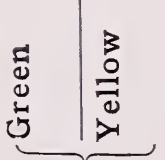

๗ู

ص
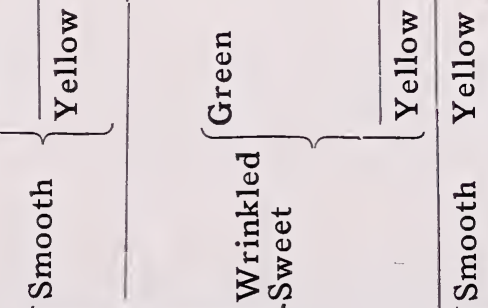

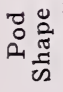

$\stackrel{\square}{\Xi}$

$\stackrel{艹}{\Xi}$

ت⿴囗十心

我

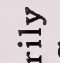




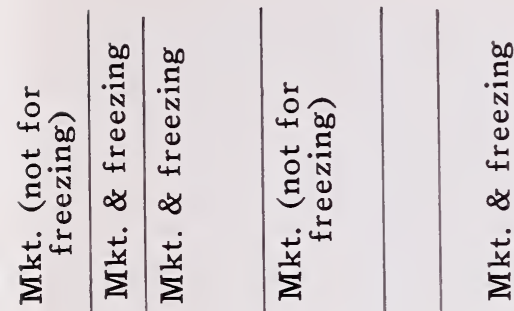

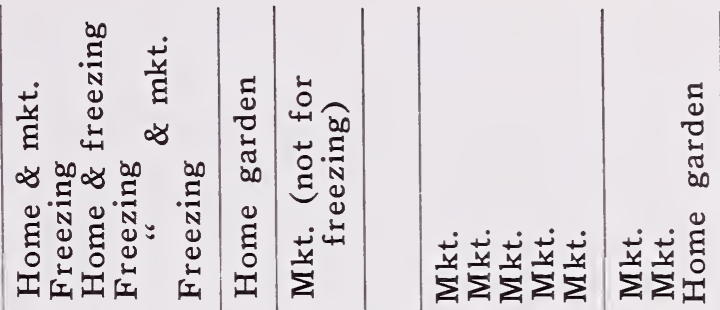

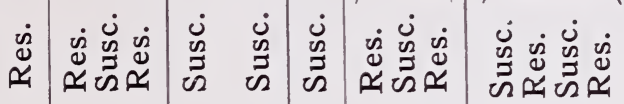

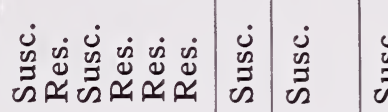

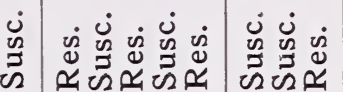

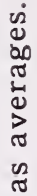

(1)

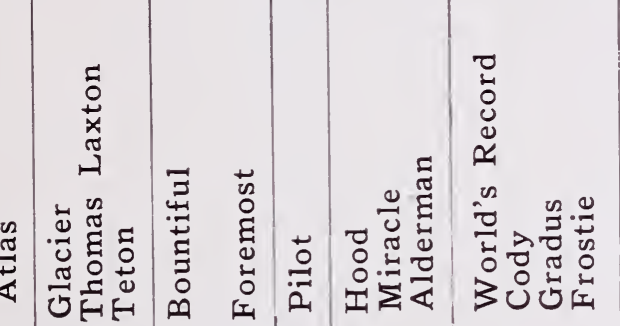

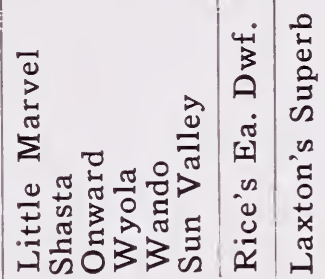

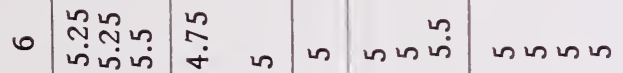

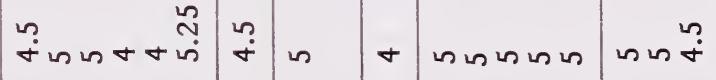

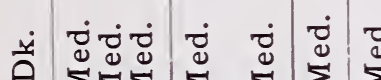

غن

ثُشن

苛

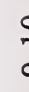

ż $\sum \sum \sum$

|

음 몾 $\operatorname{ag} 0$

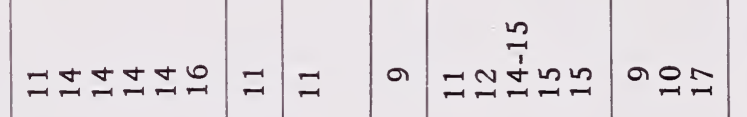

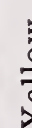

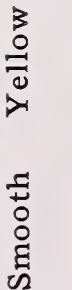

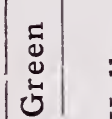

$\underbrace{9}$

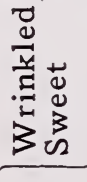

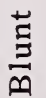
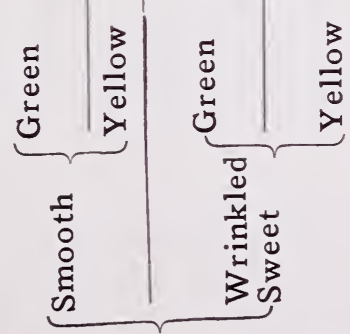

$\stackrel{0}{\stackrel{D}{\Xi}}$

$\underbrace{n}$
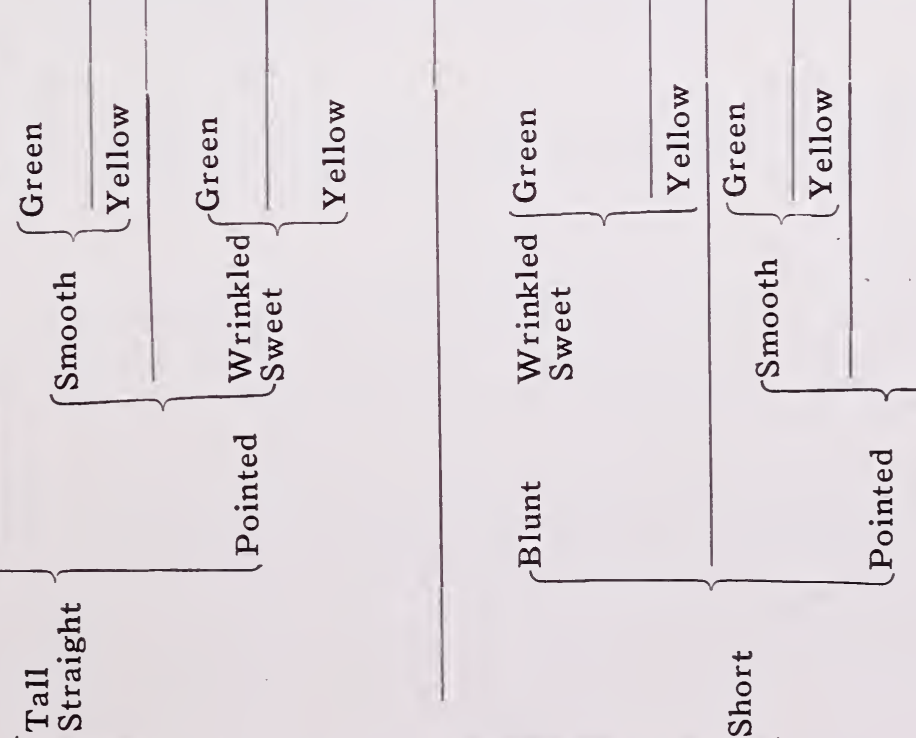

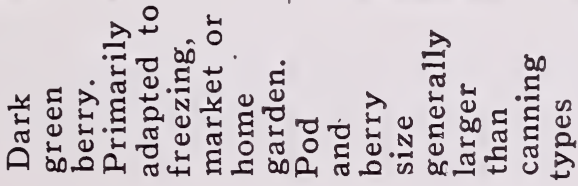

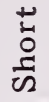




\section{CORN-Continued OPEN-POLLINATED}

CLARK'S EARLY EVERGREEN (w)

One of the best known of the older canning varieties. Origi-

Height Length
of stalk of ear

feet inches

$8 \mathrm{I} / 2 \quad 7 \mathrm{I} / 2 \quad 90$

nated by Everett B. Clark on our Milford, Connecticut, farms many years ago. Ears 2" diameter, 16-20 rowed. Kernels very deep, ivory white, sweet and tender.

COUNTRY GENTLEMAN (SHOEPEG) (w)

A prolific variety of excellent quality. Stalk often with two

ears, 17/8" diameter. Kernels very deep, slender, sweet, with tender hull, and set irregularly without row formation.

STOWELL'S EVERGREEN (w)

The best known late variety of open-pollinated white sweet $8 \mathrm{x} / 2 \quad 8$

corn. Used extensively by canners for a standard product.

Stalk sturdy and erect; ears 2I/8" diameter, 16-20 rowed. Kernels clear white, deep, rather broad, sweet and tender.

\section{CUCUMBER}

The breeding of new strains and improvement of standard varieties of cucumber is carried on at the Asgrow stations in California and Connecticut, where markedly successful types have been developed.

The column of Days indicates the relative time required from planting of seed to first picking of fruits. The figure should be reduced by several days for small pickles.

The letters b.s. indicate black spined varieties.

CHICAGO PICKLING, b.s.

A sturdy well-known pickling variety. Fruits medium green, Length Diameter
of fruit of fruit inches inches Days nearly square ended; very prolific; well warted and ribbed at pickle size; uniform and attractive; largest of the pickling sorts.

GHERKIN, WEST INDIA

Not a true cucumber. Used for very small pickles. Fruits pale green, covered with prickly spines; oval and uniform.

NATIONAL ASSOCIATION PICKLING, b.s.

A highly desirable, very extensively used pickling strain developed at the Michigan Agricultural College in collaboration with the National Pickle Packers' Association. Fruits dark green, symmetrical with thick walls; full ended; slightly shorter than Chicago Pickling.

SNOW'S PERFECTION PICKLING, b.s.

A somewhat smaller sort than Chicago Pickling. Early, prolific, and rightly popular. Fruits deep green, and distinctly square ended, uniform, and attractive.

\section{DILL}




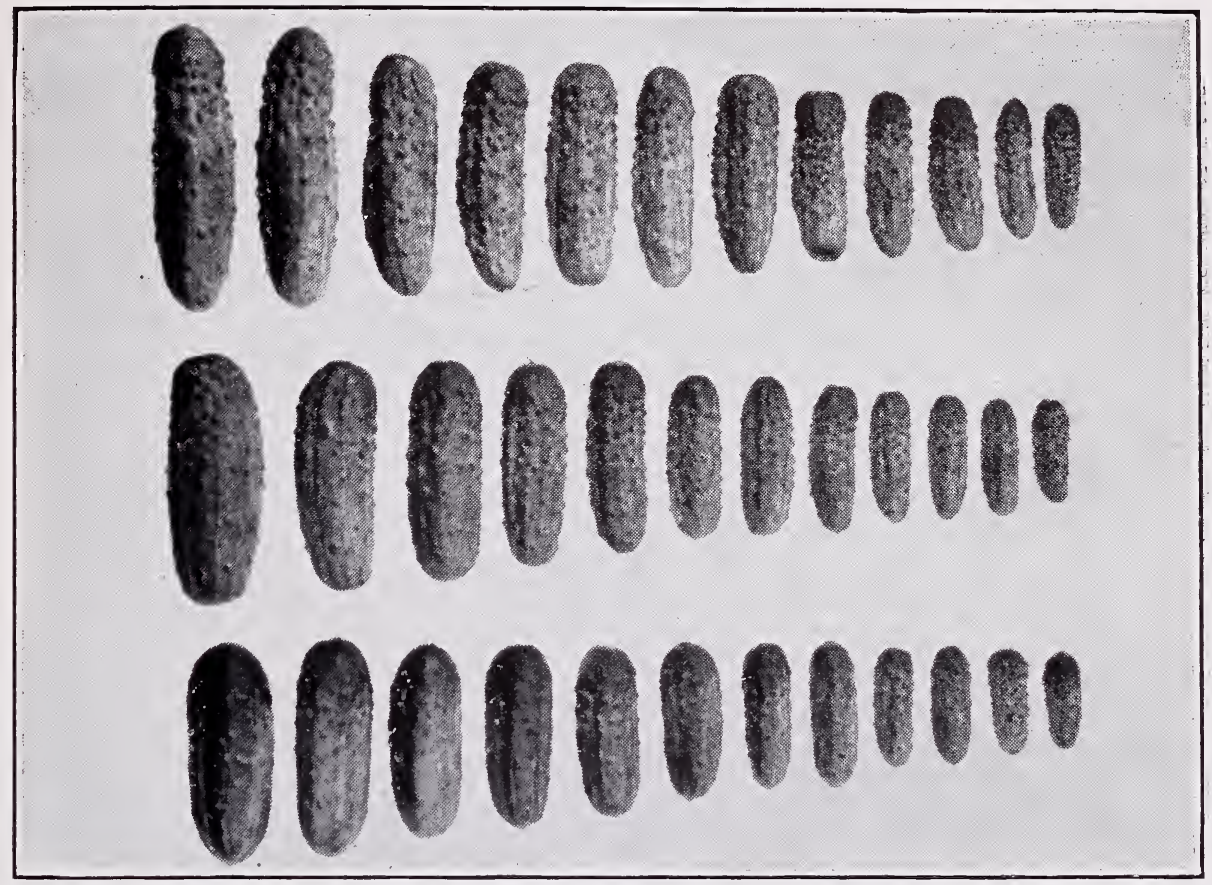

Pickling cucumbers: top, Chicago: centre, National Ass'n.: bottom, Snow's

KALE

DWARF BLUE SCOTCH

$\begin{array}{cl}\begin{array}{c}\text { Height } \\ \text { of plant } \\ \text { inches }\end{array} & \text { Days: } \\ 14 & 55\end{array}$

Plant has wide-spreading, finely curled blue-green, plume-like leaves. Used as a vegetable, and for ornament. The Asgrow pedigreed strain is exceptionally uniform and handsome.

DWARF GREEN SCOTCH

A hardy sort, similar in habit of growth and appearance to Dwarf Blue Scotch, except for color, which is bright, deep dark green. The Asgrow pedigreed strain is large and very attractive.

\section{MUSTARD}

\section{CHINESE BROAD LEAVED}

Plant medium large, vigorous; leaves broad, large, slightly crumpled, oblong, medium green, scalloped at edges; seed reddish brown.

\section{FORDHOOK FANCY (OSTRICH PLUME)}

A handsome, upright growing, mild variety, slow to bolt seed stalks; leaves bright green, plume-like, and deeply fringed on the edges; seed reddish brown.

\section{MUSTARD SPINACH (TENDERGREEN)}

A quick growing variety particularly suited to the South. Leaves oblong, thick, fairly smooth, dark green with lighter green ribs; slow to seed, resistant to heat and drought; combines flavors of mustard and spinach.

\section{SOUTHERN GIANT CURLED}

The best known and most popular sort for canning "greens." Leaves long and wide, light green, tinged with yellow, heavily crumpled and curled at the edges. Seed small, reddish brown. Used widely in the South. 


\section{OKRA}

\section{CLEMSON SPINELESS}

Developed by the South Carolina Experiment Station. AllAmerica Silver Medal for 1939. A very uniform spineless strain of the Perkins' type. Plant has less foliage than Perkins'; pods rich green, straight, ridged.

$\begin{array}{lcr}\text { Height } & & \\ \text { of } & \text { Mature } & \\ \text { plant } & \text { pods } & \\ \text { feet } & \text { inches } & \text { Days } \\ 4 \mathrm{I} / 2 & 6 & 55\end{array}$

LOUISIANA VELVET (LADY FINGER)

An improved strain of White Velvet. Plant tall, early and prolific. Pods creamy white, slender, spineless, ribless.

PERKINS' MAMMOTH (TALL GREEN)

Pods bright, deep green, slender, meaty, tapered, and ribbed. A valuable canning variety.

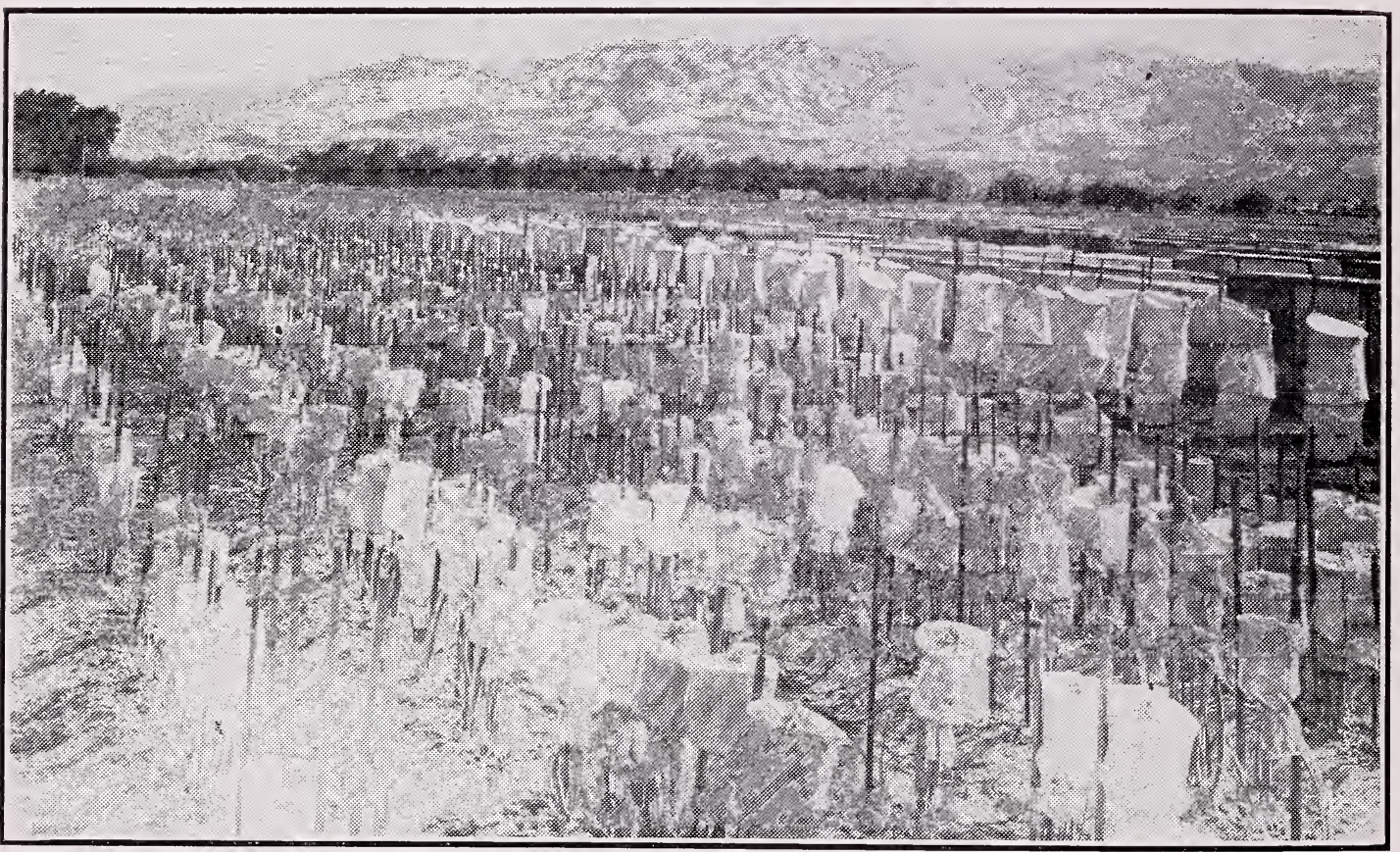

Onion breeding plot at our Pacific Coast station

\section{PICKLING ONIONS}

WHITE BARLETTA (WHITE PEARL)

An early sort, used for pickling. Bulbs small, more or less spherical when young, flattening later, pure white, of mild, sweet flavor.

WHITE PORTUGAL (SILVERSKIN)

The most widely used all-purpose white onion. Bulbs medium sized, thickflat, clear white, hard, fine grained, and of pleasing flavor. A dependable cropper.

Very similar to White Barletta; a well known pickling variety. Bulbs small, flat, clear white, firm and mild. 


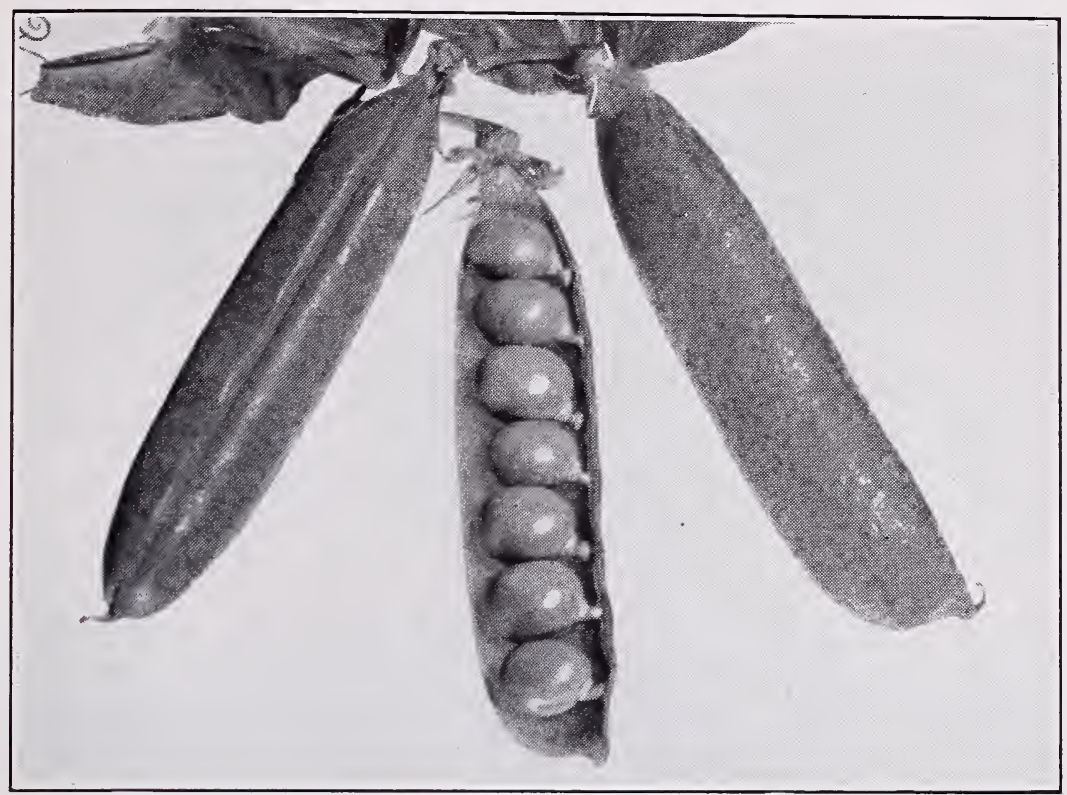

Thomas Laxton: our celebrated dark-podded strain

\section{PEAS}

One of the most important Asgrow plant breeding stations is located at Hamilton, Montana, devoted exclusively to the maintenance or improvement of our stocks of standard varieties and to the development of new types embodying disease resistance, yield, quality or other specifications to meet the needs of the packing industry.

Among the recent introductions from this station which have speedily won wide acceptance are Pride, Canner King, and Shasta; several other new varieties are listed hereunder, and some of them may prove equally successful.

Since the time from planting to first picking varies widely in different seasons and in different sections, the column of days gives average results under normal rainfall conditions in the North. These figures will be of assistance in comparing the relative earliness or lateness of the various varieties when planted in any locality.

Smooth seeded sorts are commonly handled on the basis of $120 \mathrm{lb}$. to the bag and wrinkled varieties $112 \mathrm{lb}$.

\section{Smooth-Seeded}

\section{ALASKA}

The Asgrow strain-the first progeny line, pedigreed stock of this variety ever developed-is noted for its pod size and productivity. Fully resistant to Fusarium wilt. Used very extensively for first early canning. Vine slender, light green, very uniform in maturing. Pods single, blunt, light green, round, straight, contain 6-8 peas of good quality; sieve sizes 1 to 5 , largely 3 and 4 . Seed small, round, smooth, bluish green: 130 per oz.

ALASKA 30

Vine more vigorous but less uniform than regular Alaska and about two days later to picking. Pods are similar but in general slightly larger; sieve sizes 1 to 6 , largely 3 to 5 . Seeds 160 per oz.

A more vigorous vined Alaska reaching canning maturity about two days later than regular Asgrow Alaska. Pods are similar but slightly larger; resistant to Fusarium wilt and a reliable cropper under adverse conditions. Sieve sizes 1 to 6, largely 3 to 5 . 125 per oz. 


\section{PEAS-Continued}

Wrinkled-Seeded

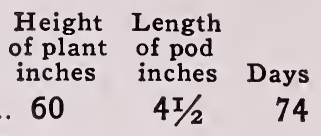

* ALDERMAN (DARK-PODDED TELEPHONE)

A handsome large podded variety, excellent for freezing. Vine dark green, coarse, resistant to Fusarium wilt. Pods single, large, plump, straight, dark green, pointed; contain 8-10 peas of highest quality. Frozen peas oblong, dark green; sieve sizes 4 to 8 . Smaller sizes should not be frozen. Seed large, light green: 90 per oz.

CANNER KING

A popular Asgrow development. Vine similar to Perfection but with more open habit of growth; color medium green. Resistant to Fusarium wilt. Pods slightly curved, single and double, medium green, blunt, contain 7-9 peas; sieve sizes 2 to 7, largely 4 to 6 . Seed green, of medium size: 100 per oz.

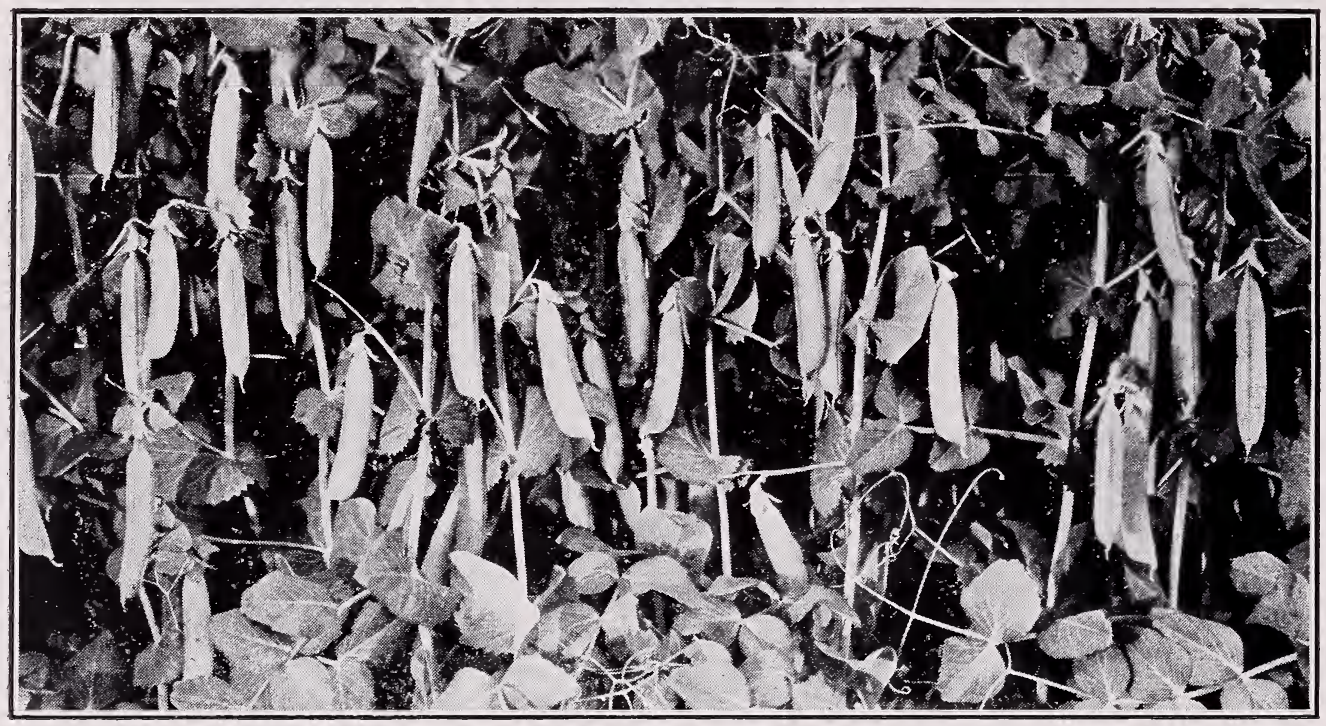

Canner King: An Asgrow introduction of high canning quality

CLIMAX

A prolific sort for second early canning. Vine of Admiral type, medium green and slender. Resistant to Fusarium wilt. Pods single and double, light, blunt; contain 6-7 peas. Sieve sizes 1 to 5 . Seed small, green: 140 per oz.

$\star \mathrm{CODY}$

A new first early market and freezing variety recently developed by Asgrow. Of Gradus type but earlier and resistant to Fusarium wilt. Vine light green, medium heavy. Pods single, dark green, pointed, broad, plump, containing 7-9 large oblong deep green tender peas. Sieve sizes 3 to 7.90 per oz.

DELWICHE COMMANDO

The first variety resistant to both common pea wilt and nearwilt, developed by Profs. E. G. Delwiche and J. C. Walker of Wisconsin from Pride and Green Admiral. Very similar to Perfection in type of plant and pod, but a day or so earlier, and the pods a little smaller. Seed 130 per oz.

$\star$ Suitable for quick freezing. 
$\star$ DWARF ALDERMAN

Vine dark green, stocky, resistant to Fusarium wilt. Pods $28 \quad 4 \frac{I}{2}$ single and double, dark green, plump, pointed, slightly curved; contain 7-9 large peas, sieve sizes 3 to 7 and a few larger. Seed large, green, wrinkled: 85 per oz.

EARLY HARVEST

Our development, resistant to Fusarium wilt. An early sweet wrinkled canning type showing more vigor than either Surprise or Wisconsin Early Sweet. Vine thrifty, medium green. Pods single, light green, plump, blunt; contain 6-8 peas having tender skins and excellent flavor. Canned peas round, light green, sieve sizes 1 to 5 , average 3.2. Also very attractive run-of-pod. Seed small, green: 140 per oz.

EARLY PERFECTION

An Asgrow introduction valuable to canners as a desirable sweet wrinkled pea maturing between Surprise and Perfection. Vine dark green, thrifty. Pods single and double, blunt, light green, plump; contain 7-8 peas of good quality. Canned peas semi-round, medium green; sieve sizes 1 to 6 . Seed medium sized, green, wrinkled: 130 per oz.

$\star$ FROSTIE

An improved Gradus type for canning and freezing. Vine

medium green, stocky. Pods single, broad, plump, pointed, medium green; contain 8-10 large, sweet, delicious peas. Frozen peas oblong, deep green; sieve sizes 3 to 7 . Seed large, cream and green: 100 per oz.

$\star$ GLACIER

An attractive Asgrow variety developed at our pea-breeding

\section{2} station to meet the need for a variety somewhat earlier than Thomas Laxton but of the same general type and fully resistant to Fusarium wilt. The vines are dark green and medium heavy. Pods single, dark green, blunt ended, plump and well filled with 7-8 deep green, semi-round peas of excellent quality for canning or freezing; sieve sizes 3 to 7 . Seed large, cream and green: 102 per oz.

\section{Glacier:}

similar to

Thomas Laxton

but earlier

and wilt

resistant

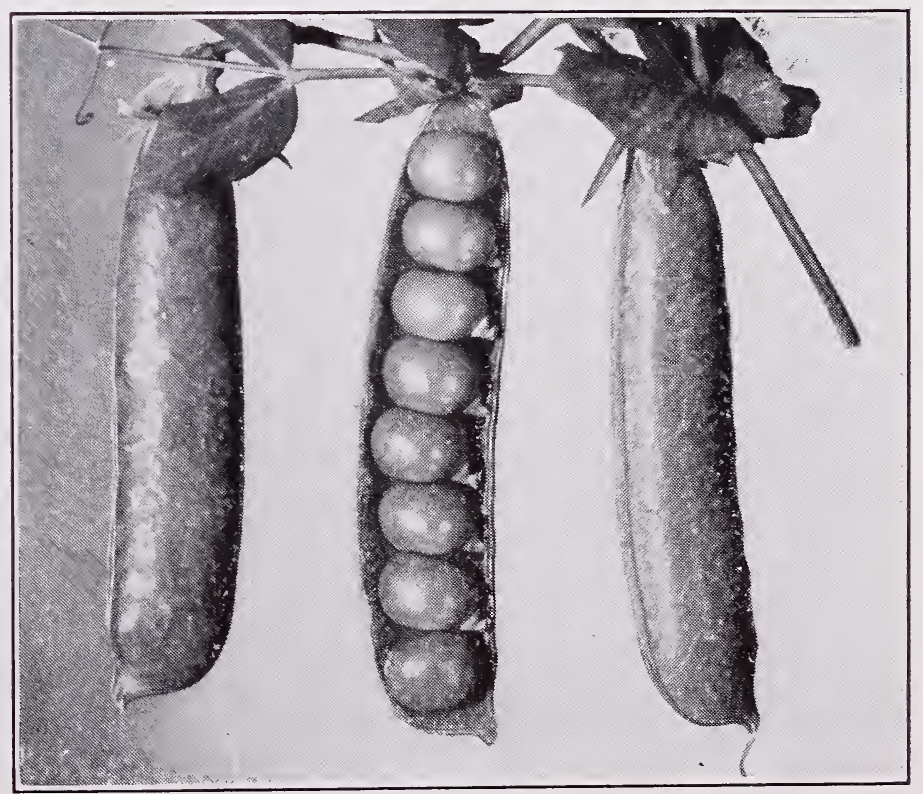

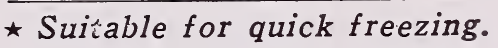




\section{PEAS-Continued}

HORSFORD'S MARKET GARDEN

$\begin{array}{clr}\text { Plant } & \text { Pod } & \text { Days } \\ 28 & 3 & 76\end{array}$

Principally a canning variety. Vine productive, dark green, thick stemmed and branching. Pods double, light green, plump, blunt, straight; contain 6-7 uniform peas of good quality; sieve sizes 1 to 5 , largely 3 to 5 . Seed medium sized, green.

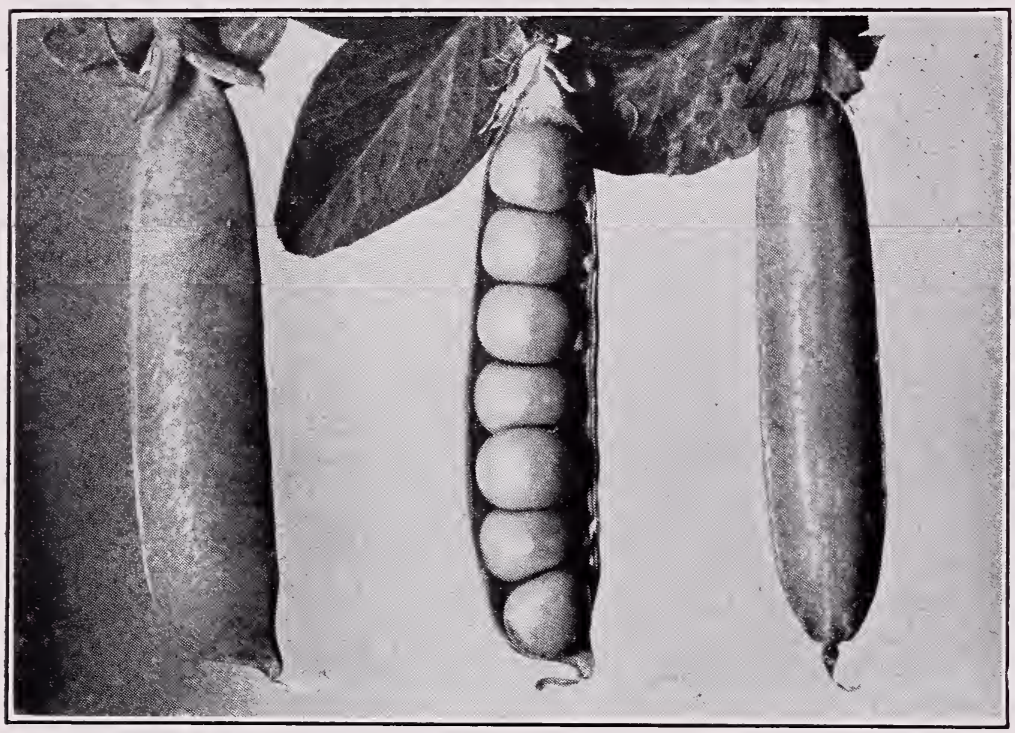

Early Harvest:

An Asgrow variety; early, vigorous and of excellent canning quality

$\star$ HUNDREDFOLD (LAXTONIAN)

A large podded dwarf variety for canning and freezing. Vine dark green. Pods single, broad, dark green, slightly curved, pointed; contain 7-8 large, oblong, deep green peas; sieve sizes 3 to 7, largely 5-6. Seed large, flattish, yellow and green: 95 per oz.

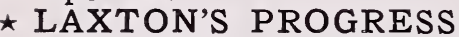

The largest podded and most attractive of the Laxtonian family.

Vine medium dark green. Pods single, $7 / 8$ " wide, dark green, somewhat curved, pointed, handsome; contain 7-9 large, oblong, deep green peas of good quality; sieve sizes 3 to 7 . Seed large, cream with green: 85 per oz.

LOYALTY

A new dwarf early sweet type possessing an ability to crop under adverse weather conditions. In developing this variety at our pea-breeding station, particular attention was given to incorporating the factors for resistance to heat, moisture, and aphids. Fully resistant to Fusarium wilt. Vine dark green, concentrated pod setting, pods double, straight, plump, well filled with 7 to 9 medium green round peas; sieve sizes largely 3,4 and 5 . Seeds 120 per oz.

MAJOR

Developed at our pea-breeding station, this recent variety combines the best qualities of Perfection and Profusion. Resistant to Fusarium wilt. Vine stocky, of open growing habit, medium green. Pods mostly double and well concentrated, nearly straight, blunt, well filled with 6-7 large bright green peas of excellent quality. Sieve sizes 3 to 7 , largely 5 to 7 . Seed large, mainly green: 95 per oz.

$\star$ MIRACLE

This English variety, which has given good results in quick

freezing, may be described as of Alderman type but with shorter, lighter-colored vine and somewhat smaller pod; not resistant to wilt. Vines medium green, pods large, single, slightly curved, pointed; with very dark green berry of sieve sizes $3-7$, averaging 5 . Seeds 100 per oz. 
$\star$ MULTIFOLD

Our recent introduction of large Hundredfold type, developed

at our pea-breeding station for quick freezing and general use. Resistant to Fusarium wilt. Vine dark green, strong and prolific. Pods single and double, broad, dark green, pointed and slightly curved; contain 8 large, dark green peas of excellent quality, sieve sizes 3 to 7 . Seed large, green: 100 per oz.

$\star$ NUMBER 40

Resembles Stratagem, but 4-5 days earlier; exceptional in pod Fusarium wilt. Pods single and double, round, dark green, plump, pointed, curved at tip; contain 8-10 large, succulent peas; sieve sizes 3 to 7 , and a few larger. Medium dark green when frozen. Seed large, green: 90 per oz.

NUMBER 71

A reliable and prolific canning variety. Vine slender, mediumdark green; resistant to Fusarium wilt. Pods blunt, single and double, with 6-7 peas of sieve sizes 2 to 5 . Seed small, wrinkled and green: 140 per oz.

PERFECTION

An important main crop canning variety, resistant to Fusarium 30 wilt; concentrated in pod development and very productive. The Asgrow strain is known particularly for its uniform, large, attractive pods. Vine medium green, stocky. Pods double, medium green, blunt, slightly curved; contain 7-9 peas. Canned peas semi-round, medium green; sieve sizes 1 to 6, largely 3 to 5. Seed green, of medium size: 130 per oz.

PRIDE

Developed at our pea-breeding station and introduced in 1936. 30 A vigorous variety, exceptionally productive. Resistant to Fusarium wilt; excellent for canning, especially the larger sieve sizes; similar in color and texture to Perfection. Vine dark green, open at top, sturdy, very uniform, quite resistant to aphids. Pods mainly double, straight, plump, dark green, well filled with 7-9 medium deep green, semi-round peas; sieve sizes 1 to 6 , largely 3 to 5 . Highly concentrated in season and produces crops of quality peas under adverse conditions. Seed medium, green: 120 per oz.

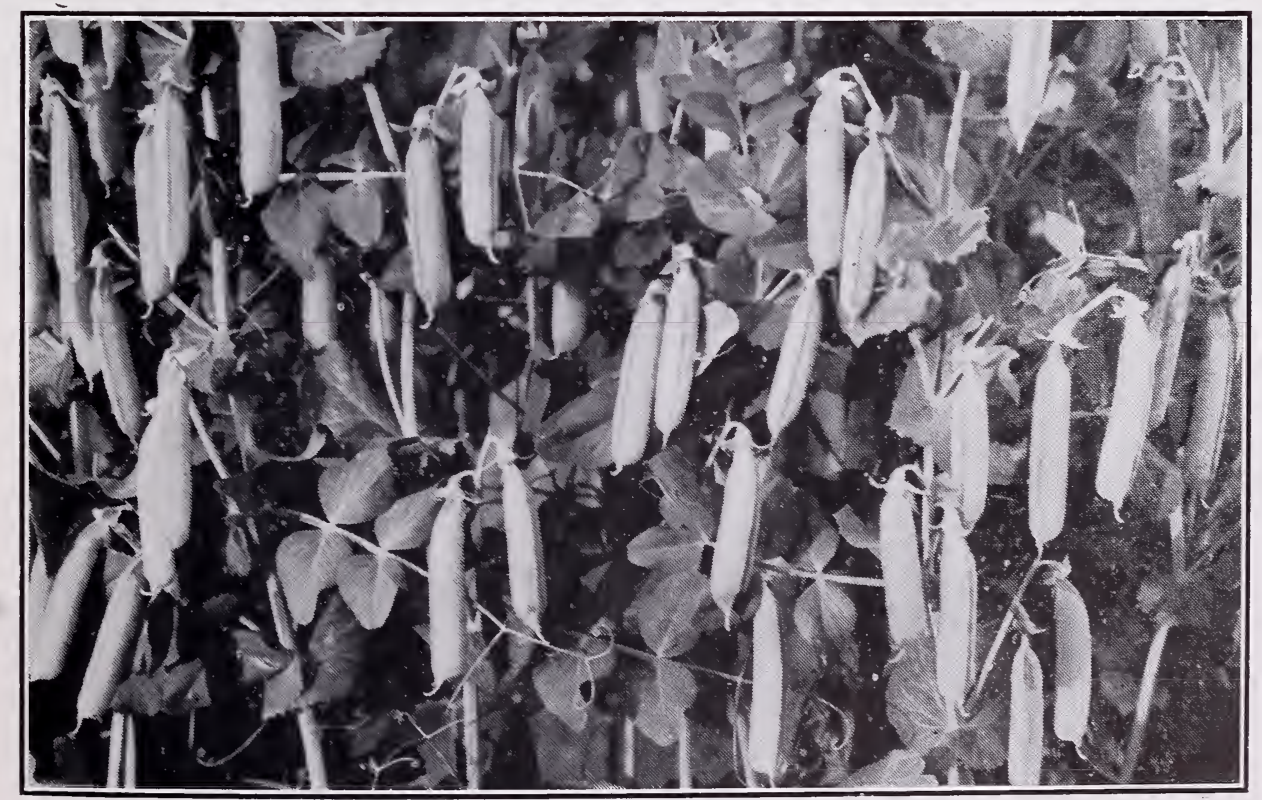

Pride: a highly successful Asgrow introduction 


\section{PEAS-Continued}

PRINCE OF WALES

$$
40
$$

A USION ....................................................................... Vine medium green, with stout stem. Pods single and paired, light green, plump, straight, blunt; contain 5-6 large, oblong peas of good quality; sieve sizes 3 to 7 , and a few larger. Seed large, cream and green: 90 per oz.

RESISTANT GEM

Resistant to Fusarium wilt. Vine dark green, medium, productive. Pods single and double, light green, round, straight, blunt; contain 6-7 peas of good quality. Canned peas oblong, medium green; sieve sizes 1 to 5, largely 3 and 4 . Seed green, medium sized: 120 per oz.

$\star$ SHASTA

Developed at our pea-breeding station to meet the need for a

late-maturing Thomas Laxton type. Plants medium green and sturdy; resistant to Fusarium wilt. Pods dark green, a little larger than Thomas Laxton and of similar shape, borne mainly in pairs. Peas deep green, of excellent quality and highly suitable for freezing. Seed large, green: 100 per oz.

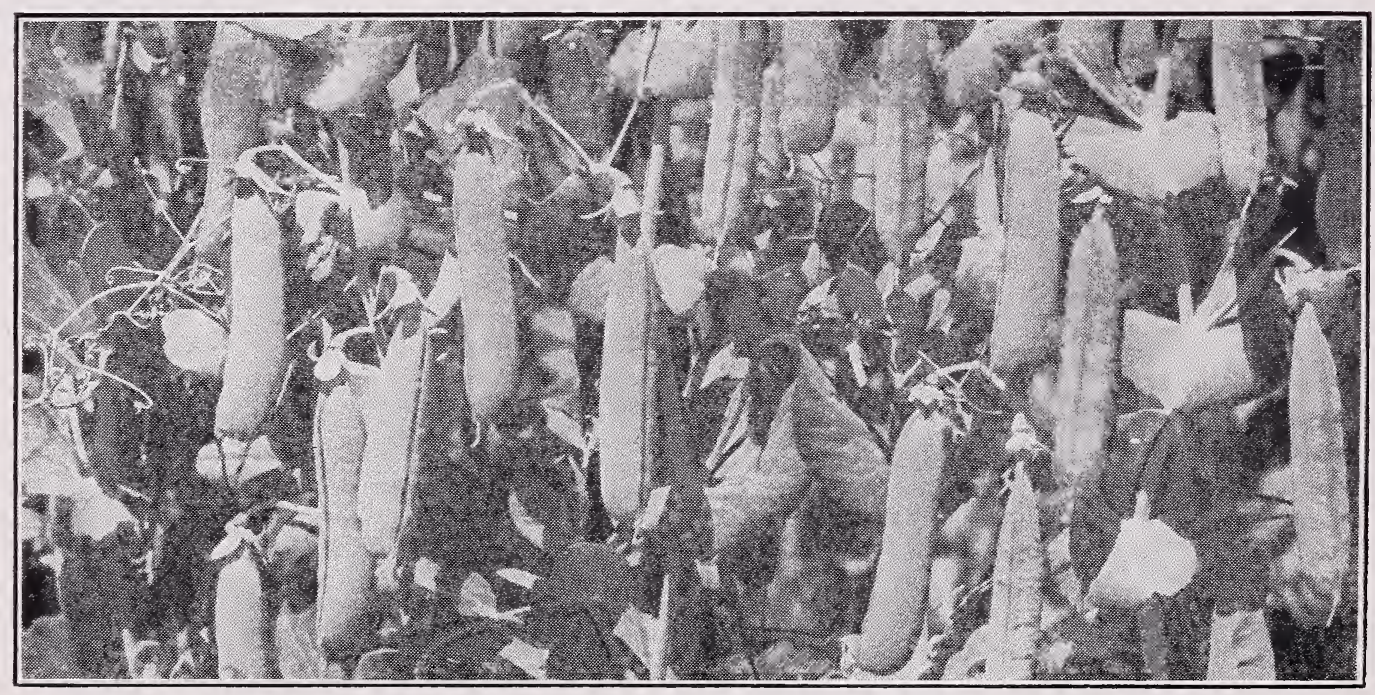

Shasta: A new Asgrow variety of late maturing Thomas Laxton type

SIGNAL

A late dwarf Profusion type with green seeds developed at our $30 \quad 3 r / 4$ 74 pea-breeding station to meet the need of canners for a late large sized run-of-pod variety of determinate growth habit. Fully resistant to Fusarium wilt. Vine dark green, pods paired, light green, plump, containing 6-8 very large peas of olive shape and excellent quality. Sieve sizes mostly 5,6 and 7 . Seeds 85 per oz.

SURPASS (RESISTANT SURPRISE)

Developed at our pea-breeding station to provide a variety with the desirable canning qualities of Surprise, plus resistance to Fusarium wilt. The new variety is somewhat more prolific, but plant and pod type are, in general, identical with Surprise. Seeds 140 per oz.

* Suitable for quick freezing. 
A popular early canning sort of first quality. Vine medium green, slender. Pods single, light green, plump, blunt; contain 6-8 round, light green peas; sizes 1 to 5 , average 3 , also excellent when ungraded. Seed small, green. This variety excels in tenderness of skin and sweetness of flavor. The Asgrow long podded pure-line strain is outstanding.

Developed at our pea-breeding station: All-America Silver Medal for 1937. An attractive variety fully resistant to Fusarium wilt. Excellent for canning and freezing. Vine dark green, medium heavy. Pods single, large, straight, blunt, dark green, concentrated in season; well filled with 7-8 large, semiround, olive-green peas of very fine quality; sieve sizes 3 to 7 , average 6. Seed large, cream and green: 105 per oz.

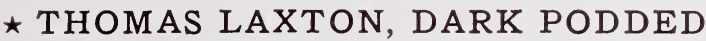

The Asgrow improved dark podded strain is very attractive in both plant and pod. Excellent for canning and freezing. Vine deep green and medium heavy. Pods single, rich deep green, plump, broad, blunt; contain 7-8 large, tender peas of splendid quality, semi-round, olive-green; sieve sizes 3 to 7 , average 5.5. Seed of medium size, cream and green: 100 per oz.

\section{WISCONSIN EARLY SWEET}

An early, sweet, canning variety, similar to Surprise, resistant to Fusarium wilt. Vine medium green, slender. Pods single, light green, plump, blunt; contain 6-7 round, light green peas; sieve sizes 1 to 5 . Seed medium small, green. 150 per oz.

Developed by Dr. E. J. Delwiche at the University of Wisconsin. A canning variety somewhat of Perfection type. Plant medium green, pods blunt, slightly curved, with 7-8 large, medium green peas; sieve sizes 3 to 6 , largely 4 and 5 . Seeds 120 per oz.

$\star$ WYOLA

An entirely new type, developed at our pea-breeding station primarily to provide the freezing industry with an early variety of small-sized dark-colored peas. The vines are of medium length, wilt-resistant and very prolific. Pods dark, highly double, blunt, well filled with 7-9 small, dark peas of sieve size 1-5. Seed small, green. 105 per oz.

\section{For Southern Canners}

An early edible podded variety. Vine dark green, thick-stemmed and branching. Pods round, plump, blunt, medium green, filled with brownish peas crowded tightly together. Seed smooth, buff-brown with darker brown eye. Through breeding work at our Southern station, the Asgrow strain has been made suitable for shelling in viner equipment. The hulls are thicker than. other varieties and do not fit too tightly around the seeds. 


\section{PEPPER}

Development of new varieties and the improvement of standard sorts are carried on at our Eastern breeding station, Milford, Conn. Our pedigreed stocks are noted for earliness in maturity and thickness of flesh. The seasonal relationship among varieties is shown by average reading of maturity dates, the column of Days indicating relative time from setting-out of plants to picking.

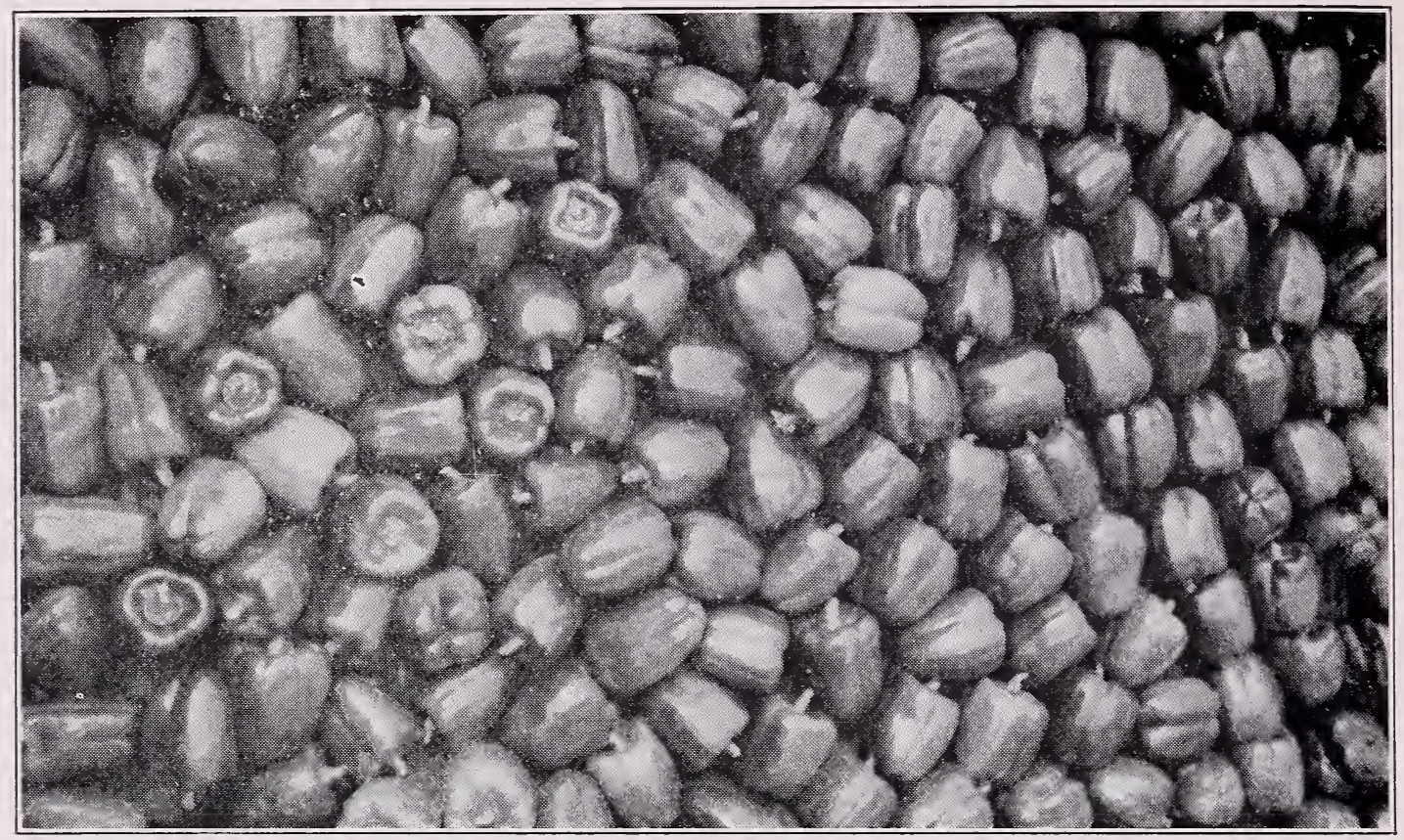

A run-of-the-field picking of Early Calwonder

\section{Diameter \\ Length at stem}

ANAHEIM CHILI

ches inches Days

An all-purpose hot variety, planted mainly in the South and in California. Long, smooth, tapering, deep green fruits, changing to bright scarlet at maturity.

CALIFORNIA WONDER, IMPROVED

Plant vigorous, upright, prolific. Fruits mostly 4-lobed, upright, slightly longer than standard strains, chunky; very attractive, smooth, uniform and deep green, changing to bright crimson; flesh very thick, sweet and mild.

EARLY CALWONDER

An Asgrow early strain of California Wonder maturing a week

$7 \quad 1$ to ten days earlier than others. Plant stocky and sturdy, vigorous, prolific. Fruits 3- and 4-lobed, upright, very attractive. Smooth, uniform, deep green changing to bright crimson at maturity; thick, sweet and mild. Particularly desirable in areas of shorter season.

FLORAL GEM

A very pungent pickling variety, used extensively in Southern California. Plant large, upstanding, very prolific. Fruit tapering, waxy yellow with reddish cheek when half mature or at pickling stage, changing to full red at maturity. Rarely used at ripe stage.

HUNGARIAN YELLOW WAX

A first early, hot sort, valuable for canners. Plant dwarf and prolific. Fruits pendent, medium slender, tapering, smooth and very pungent. Color waxy yellow changing to bright crimson at maturity. 
LONG RED CAYENNE

A favorite hot variety, used largely for canning, and in pickles ; also for drying. Plant large and productive. Fruits tapering, pendent, frequently twisted; very pungent; deep green changing to brilliant red.

\section{PIMENTO (PERFECTION)}

A valuable canning variety. Plant large, erect, prolific. Fruits heart-shaped, pendent, very smooth; color dark green, changing to bright crimson, flesh exceptionally thick, sweet and mild.

\section{PUMPKIN}

CONNECTICUT FIELD

\begin{tabular}{|c|c|c|}
\hline $\begin{array}{l}\text { Length } \\
\text { inches }\end{array}$ & $\begin{array}{l}\text { Diam- } \\
\text { eter } \\
\text { inches }\end{array}$ & Days \\
\hline 12 & 14 & 118 \\
\hline
\end{tabular}

Extensively grown for canning; often planted in corn fields. Fruits large, partly globe shaped; $15-20 \mathrm{lb}$. Surface hard, smooth, somewhat ribbed; deep orange in color; flesh thick, orange-yellow, coarse and sweet.

KENTUCKY FIELD

A heavy yielding variety widely used for canning, particularly through the South. Fruits large, slightly ribbed, not fixed in shape, some being flat, others globular and elongated; 10-15 lb.; color dull orange; flesh deep yellow, coarse, and of good flavor.

SMALL SUGAR (NEW ENGLAND PIE)

Of small handy size, but tonnage equals others. Fruits round, flattened at ends, 6-8 lb.; skin hard, smooth, somewhat ribbed, deep orange; flesh thick, sweet and dry, of bright orange color and high quality.

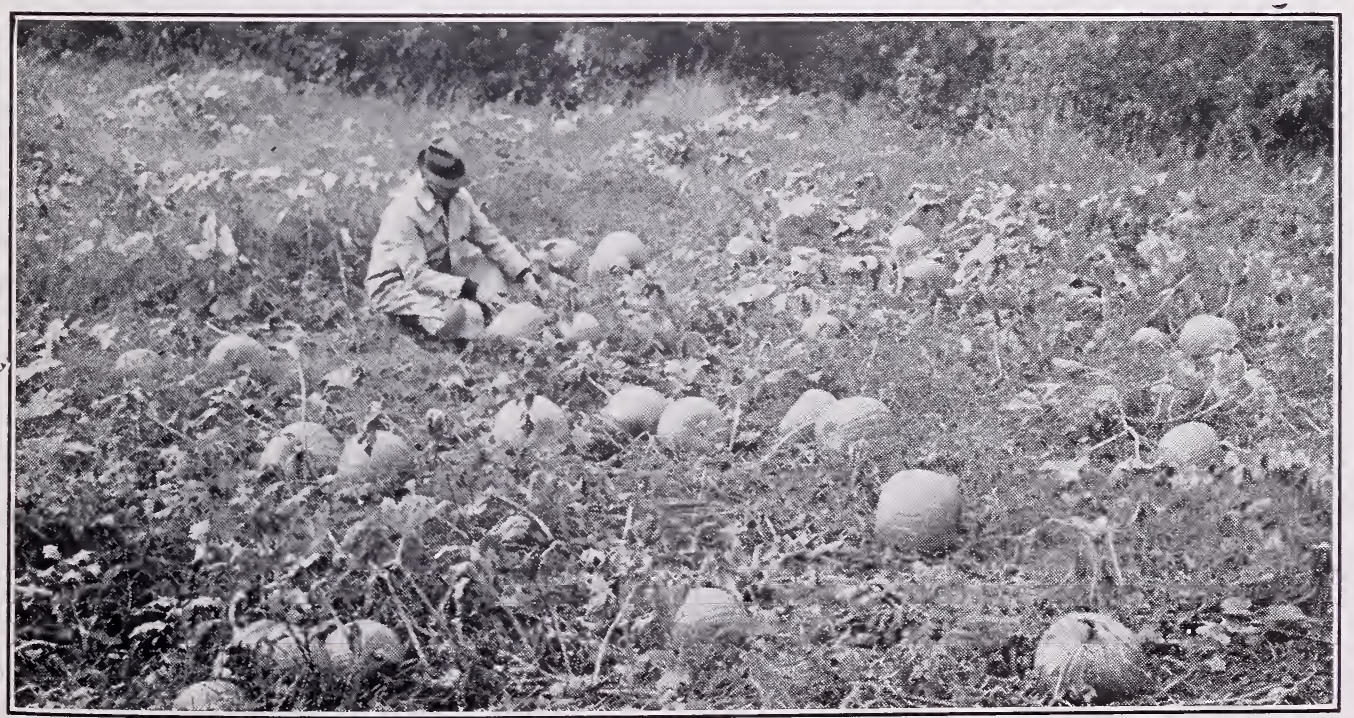

Connecticut Field: A planting at the Asgrow Eastern breeding station 


\section{SPINACH}

This necessary vegetable has been frozen more in the West than in the East, but in both sections satisfactory results have been achieved, particularly with the thick leaved sorts, though all varieties may be successfully packed if care is taken in processing to avoid loss of firm texture.

The time from planting to cutting of plants varies considerably with the season of the year in which sowings are made. The column of Days applies to spring plantings in the northern States.

Varieties marked p.s. are prickly seeded; all others are smooth seeded.

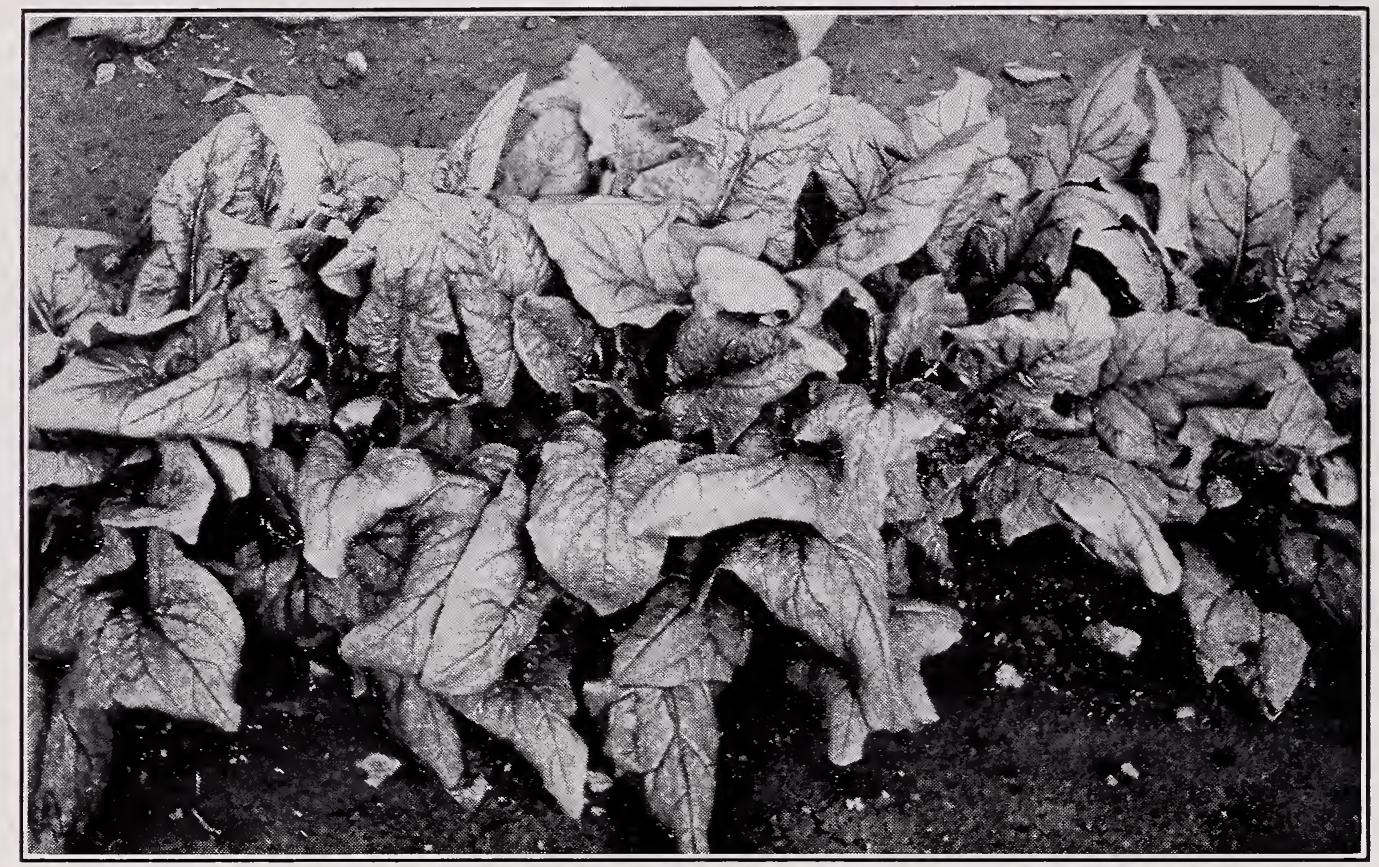

Giant Nobel: Productive, thick leafed and well flavored

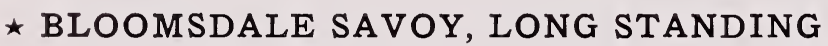

Only a few days later than other Bloomsdales, it holds 12-14 days longer before throwing seed stalks. Plant large, very uniform, erect and sturdy, with very attractive, highly crumpled dark green leaves.

$\star$ GIANT NOBEL (GIANT THICK LEAVED: MATADOR)

The best of the smooth thick-leaved sorts. Plant large, vigorous, and spreading; slow to form seed stalks, and an extremely heavy yielder. Leaves very large, thick, smooth, pointed, with rounded tip; medium green, tender. 


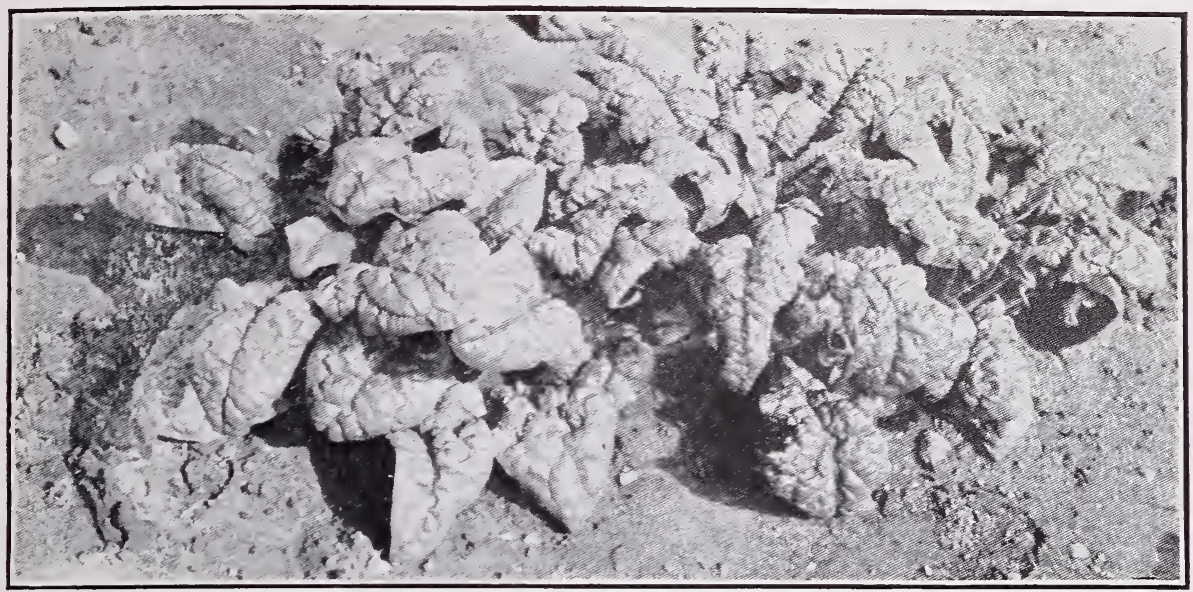

Bloomsdale Savoy, Long Standing: popular for spring sowing

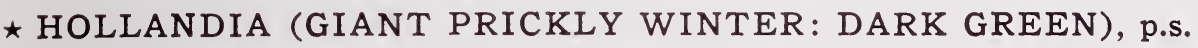

More attractive and productive than the old Prickly Winter, it is highly desirable for canners. The leaves are large, broad, arrow-shaped, and dark green. Used extensively in California.

\section{$\star$ KING OF DENMARK}

An exceptionally long standing sort, highly desirable for canning, and for market gardens. The large, spreading plants carry broad, rounded, very dark green leaves, which are somewhat crumpled. Excellent for spring planting as seed stalks are slow in forming.

$\star$ OLD DOMINION

A popular variety in Texas, resistant to mosaic and of long-standing character. Plant similar to the Savoy but leaves somewhat more pointed.

$\star$ VIKING (NORTHLAND, HEAVY PACK)

A darker leaved selection from Nobel. Excellent for canning. Plant large, spreading, vigorous, long standing and heavily productive. Leaves very large, thick, medium dark green.

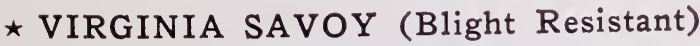

Bred at the Virginia Experiment Station for mosaic resistance. Upstanding, vigorous plants; seeding rather early; highly desirable for planting in infested soil. Leaves somewhat smoother than other strains of Savoy.

$\star$ VIROFLAY

An old extremely large, mid-season, vigorous growing variety, with long, broad, pointed, thick, smooth leaves of deep green color. Giant Nobel is now generally preferred in this class. 


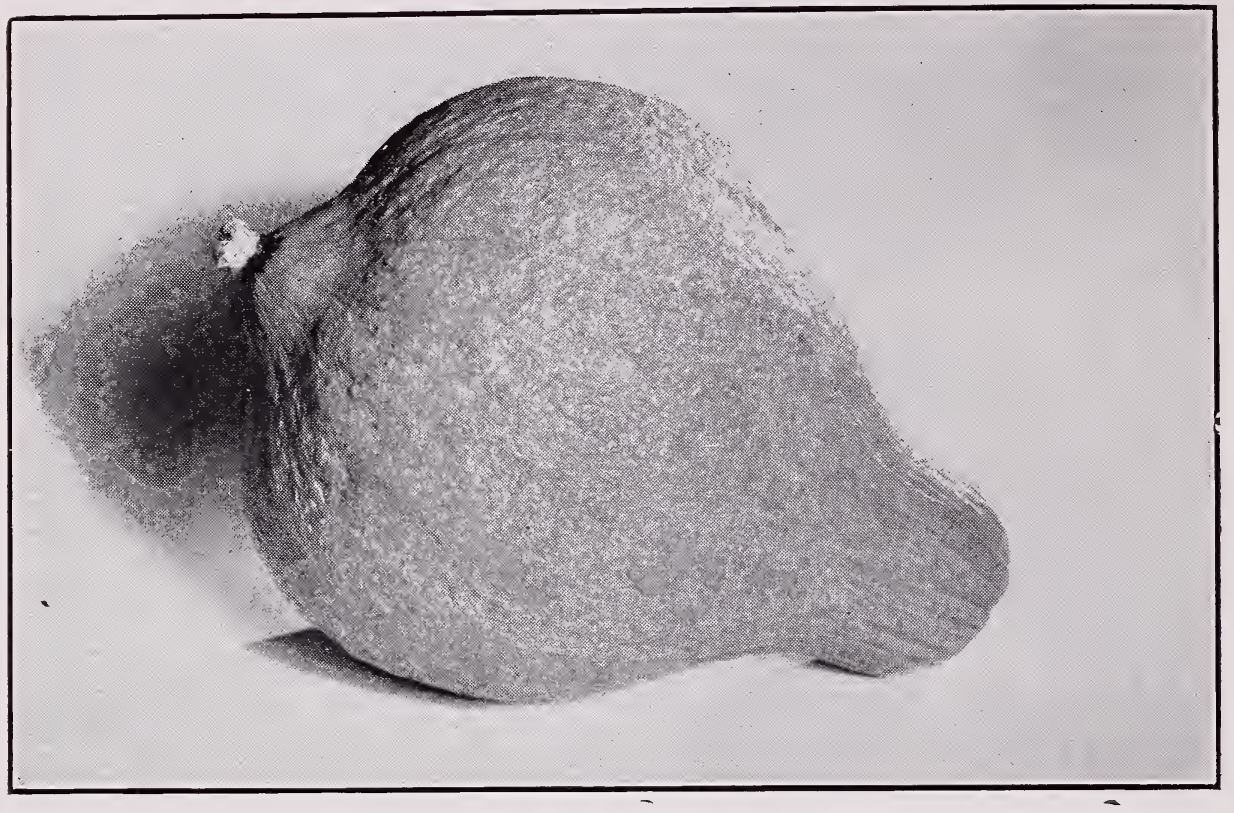

Boston Marrow: Extensively used for canning

\section{SQUASH}

Of all the vegetables, squashes exhibit the greatest range in plant and fruit characters and hybridize most readily under average field conditions. Consequently they are given special care and attention at our breeding stations in California and Connecticut. Pedigreed lines are established by controlled pollination. Increase blocks are grown in fields well isolated from any kindred variety.

The column of Days indicates the relative time from planting of seed to marketable fruits. The measurements apply to fully grown fruits.

\section{BOSTON MARROW}

A very productive, late fall variety, extensively used for caning. Resembling Hubbard in size and shape, the fruits weigh 6-8 lbs. The deep orange skin is somewhat rough, and quite hard; flesh is yellow, thick, firm, fine grained, moist. Vine of trailing type.

GOLDEN DELICIOUS MARROW

Highly desirable for canning. Fruits top-shaped, weigh $7 \mathrm{lbs}$. Color bright reddish orange, with deep green tip at blossom end. Flesh thick, medium grained, golden orange, sweet and dry.

A useful canning variety. Fruits somewhat pointed at each end, weigh 8-10 lbs., moderately warted, orange-red, with faint cream colored stripes toward blossom end; flesh deep orange, dry, and of fine quality; it keeps: well. 


\section{TOMATO}

New varieties are being developed at our breeding stations and older varieties improved through individual cultures produced under expert handling. Disease resistance, attractiveness of color, thickness of walls, and heavy cropping qualities have been attained to a high degree. Seed is also available of leading shipping and canning varieties, certified as to purity and freedom from disease by various State Departments of Agriculture.

The number of days indicated represents the time required from setting of plants to produce marketable fruits. It takes 4-5 weeks to produce plants for field setting.

Standard second early variety for canners. Vine medium, not very hardy.

Fruits slightly flattened, globe shape, of medium size; smooth, solid, bright scarlet in color, of excellent quality.

\section{CARDINAL}

An Asgrow introduction bred to provide an earlier Improved Stone type in the main crop class. Strong dark green, very prolific vines which retain their foliage through a long bearing season. Large, handsome, semi-globe fruits of rich scarlet with unusually deep interior color; smooth, thickwalled and solid, of excellent color and flavor.

CLARK'S SPECIAL "B"

Bred and introduced by us in 1922 as a main crop canning variety. Vine vigorous, somewhat open, prolific. Fruits large, deep-flat, bright red, quite free from cracks, solid; interior color deep red; small seed cells. Resembles Indiana Baltimore, but is deeper and somewhat smoother.

CLARK'S SPECIAL "C"

Also an Asgrow variety; to follow Clark's Special " $B$ " in season. Vine heavy, vigorous and prolific. Fruits very large, deep scarlet-red, flattened globe shape; very smooth and mild.

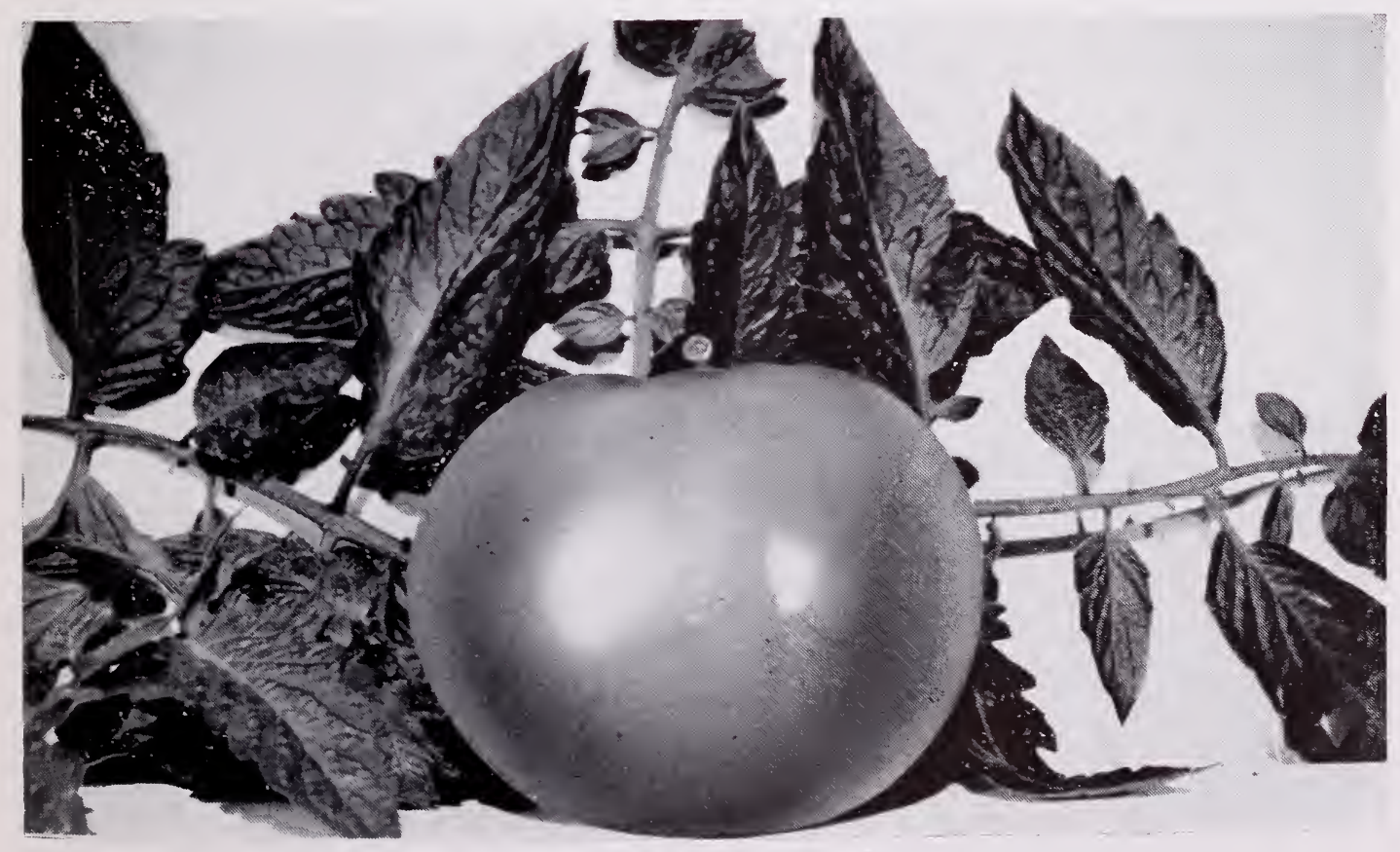

Cardinal: of Stone type but main crop maturity 


\section{TOMATO-Continued}

CLARK'S SPECIAL EARLY

Vine of medium growth, open, very prolific. Fruits medium large, globeshaped, bright scarlet, smooth, solid, with thick walls.

EARLY BALTIMORE

Developed by Prof. W. A. Huelsen, University of Illinois. Fruits oblate, smooth. Particularly adapted to Midwestern conditions.

EARLY SANTA CLARA

An early strain of this standard California canning tomato. Very uniform; fruits large, flat, deep red and meaty; of sub-acid flavor. Highly suitable for the solid pack.

GARDEN STATE

Developed by D. R. Porter of Campbell Soup Co. from a series of crosses involving Pritchard, Marvel and Pink Topper; introduced in 1944. A vigorous main crop variety with fruits similar to Rutgers but slightly larger, heavier and earlier.

GOLDEN QUEEN

The leading large yellow variety. Plant of medium size. Fruits flattened globe, medium large, deep golden yellow; smooth, rather solid, of mild flavor.

GREATER BALTIMORE

Vine large, vigorous, somewhat open. Fruits flat, medium large, deep scarlet, fairly solid and firm.

INDIANA CERTIFIED ASSOCIATED BALTIMORE

This earlier, deeper-fruited Asgrow strain is particularly desirable for canners of the East and Midwest; certified free from seed-borne diseases by Purdue University Agricultural Experiment Station. Vine large with medium heavy foliage. Fruits large, thick-flat, smooth, deep red, solid and attractive; good for juice as well as regular pack.

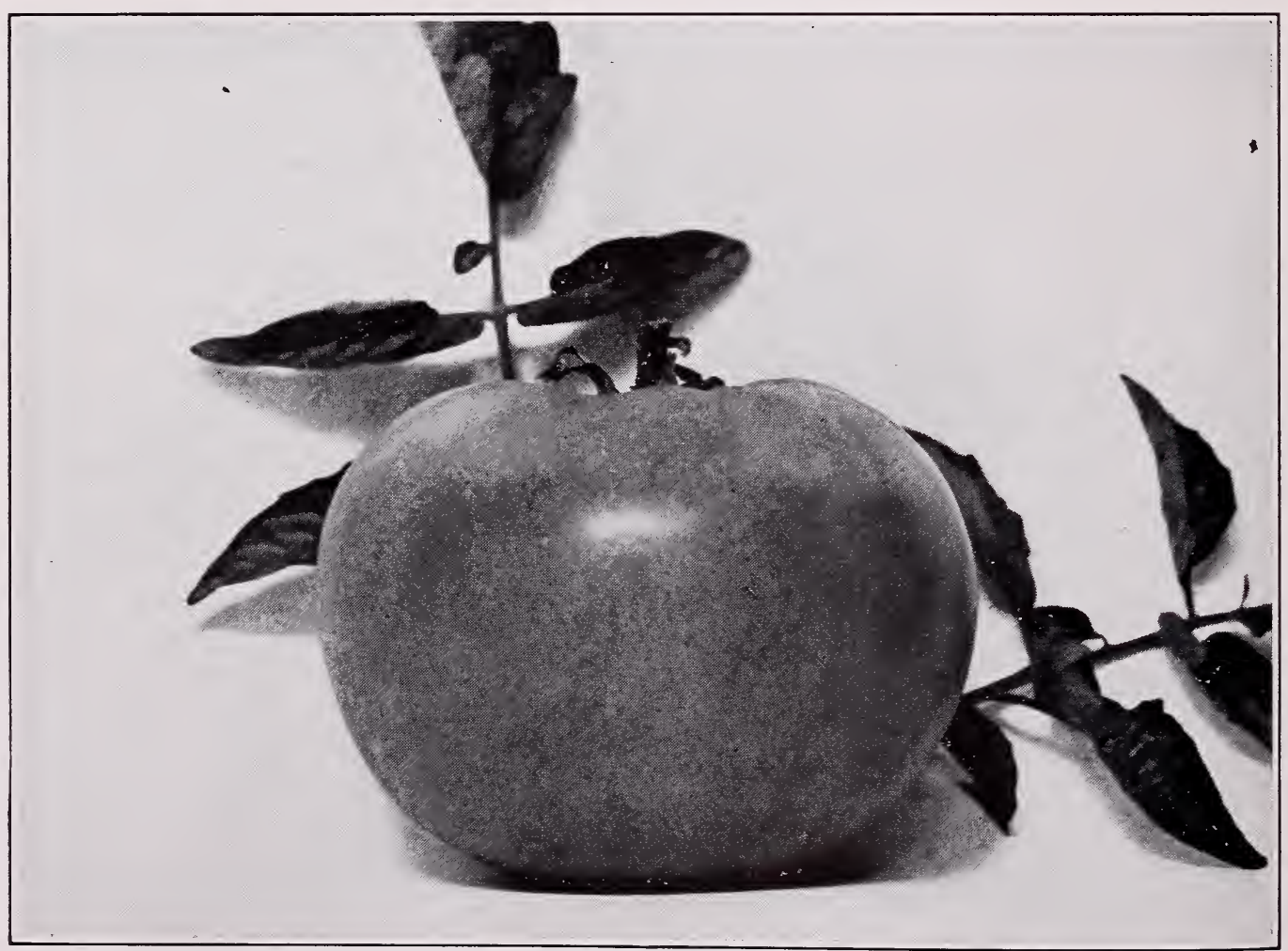

Indiana Certified Associated Baltimore: a very desirable strain 


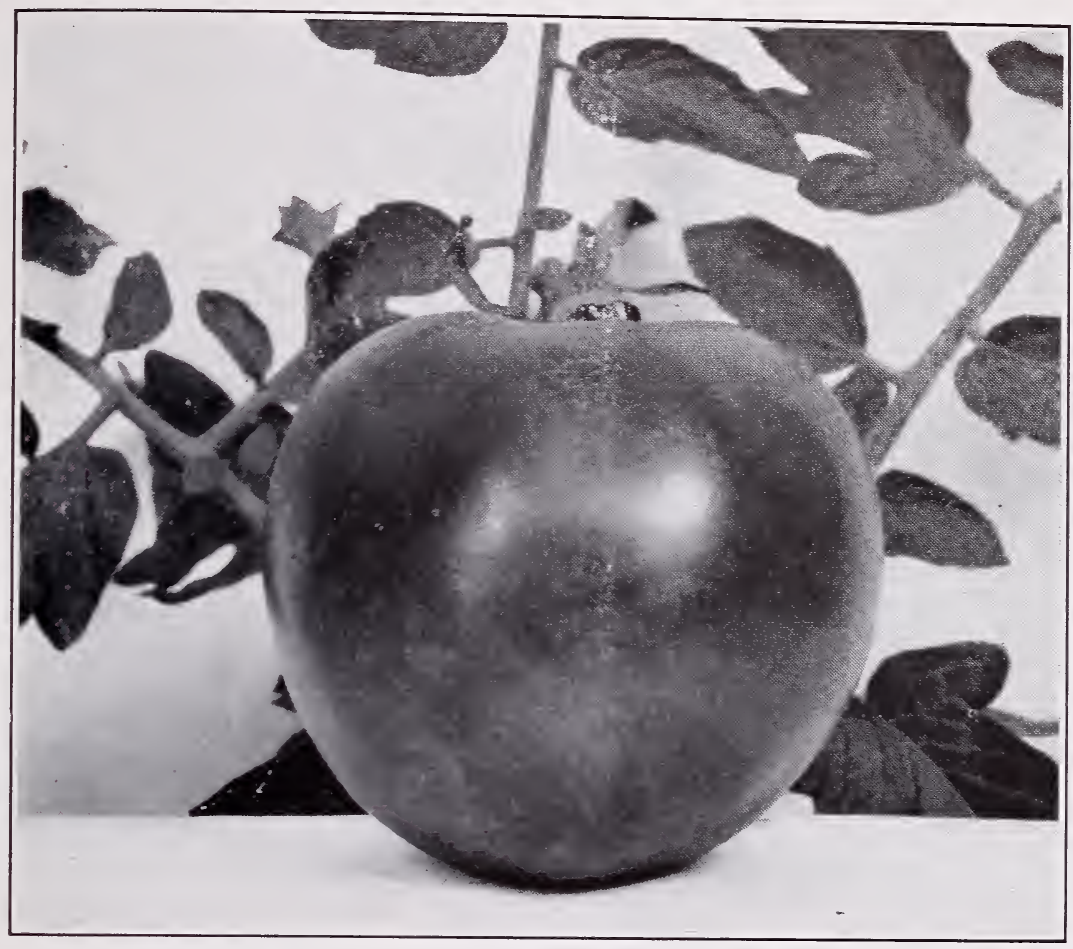

Marglobe: a wilt-resistant variety

JOHN BAER

An early sort maturing between Earliana and Bonny Best. Excellent for canning. Vine of medium height and open growth. Fruits medium size, smooth, semi-globular, attractive deep scarlet, with medium walls and small core. The Asgrow strain is exceptionally early.

\section{MARGLOBE}

Vine vigorous, with heavy foliage, partially resistant to Fusarium wilt and nail-head rust; moderately productive. Fruits medium large, nearly globular, deep red, smooth, solid, with thick walls and cross-sections; of fine quality.

\section{CERTIFIED MARGLOBE}

The Asgrow strain of this well known variety is distinguished for its freedom from puffiness, increased depth and heavier yield. Vine vigorous, dark green, partially resistant to Fusarium wilt and nail-head rust, quite productive. Fruits large, nearly round, smooth, bright deep scarlet with solid interior and small seed pockets; flavor mild.

\section{MINGOLD}

Developed at Minnesota Experiment Station. All-America Silver Medal for 1940. An excellent yellow-fruited variety, early and prolific. Fruits medium large, globular, smooth; of mild and pleasant flavor.

\section{NORTON}

A wilt-resistant variety, similar to Stone, introduced by the U. S. Dept. of Agriculture. Vine medium heavy and productive. Fruits large, flattened globe-shaped, deep cardinal-red; solid, and of excellent quality. 


\section{TOMATO-Continued}

PAN AMERICA

Recently developed by the U. S. Department of Agriculture at Beltsville, Md., from a cross of a small-fruited Peruvian variety and Marglobe. Highly resistant to Fusarium wilt. Fruits globular, of medium large size, bright red color and thick walls, heavily set. Plant semi-open, with moderately heavy foliage.

PEARSON “C”.

Developed at the College of Agriculture, California and released in 1937. A variety in the main-crop class, primarily for canning. Vigorous vines with ample foliage to protect the fruits, which are medium large, semi-globe and of good red color. Its tough skin is of value to the canner.

\section{PRITCHARD}

Introduced by the U. S. Dept. of Agriculture. All-America Gold Medal 1934. Vine self-topping, tolerant to Fusarium wilt and and nail-head rust. Fruits nearly globular, with thick walls; color light scarlet, not so intense as could be desired.

\section{RUTGERS}

An excellent canning variety of wide adaptation. Bred from Marglobe and J.T.D., it combines the best qualities of both, including Marglobe's resistance to disease and J.T.D.'s habit of ripening from the interior outwards. Vine large with thick stems and vigorous foliage. Fruits globular; bright red, smooth with thick walls and small seed cells.

\section{CERTIFIED RUTGERS}

By careful selection over a period of years, we have developed a very choice deep-fruited strain of Rutgers, notable for its uniformity and high yield of U. S. No. 1 fruits. It is available only in Asgrow containers, and bears Experiment Station certification as to trueness to type and freedom from seed-borne diseases.

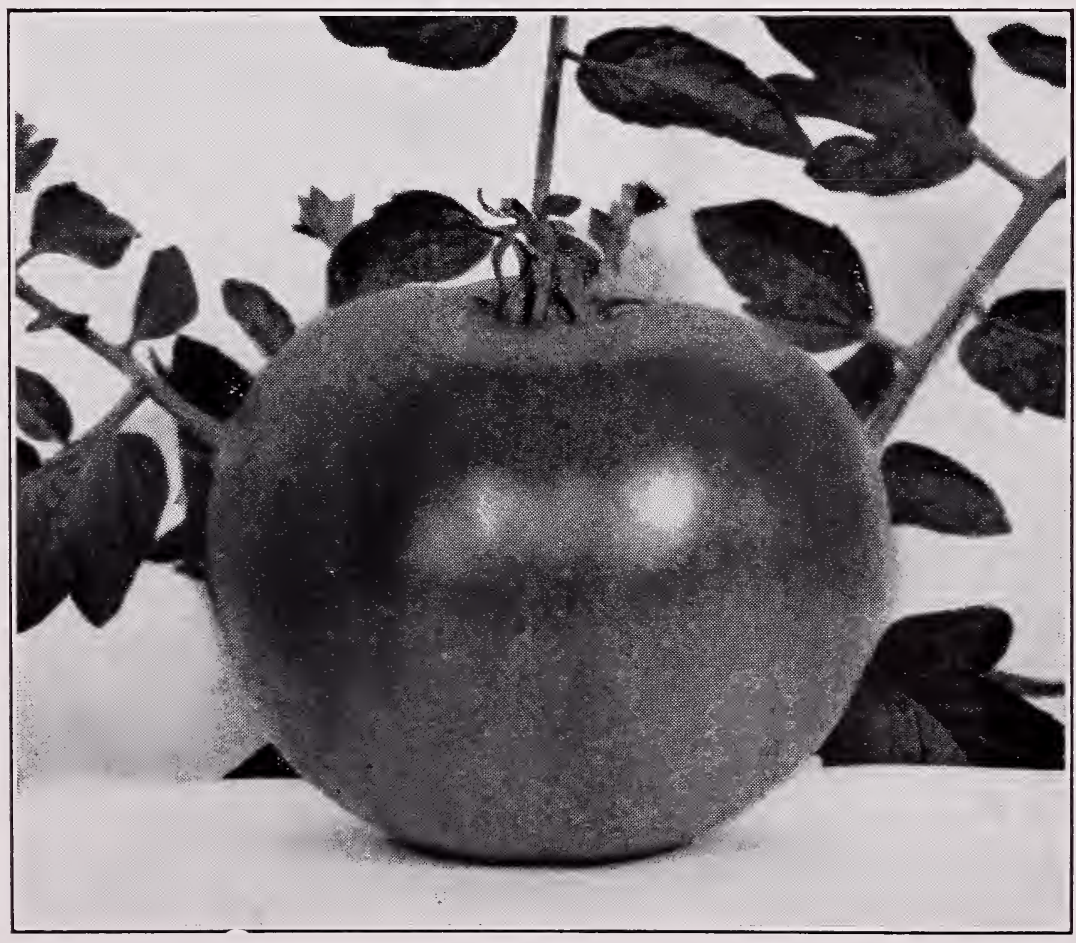

Rutgers: the most popular tomato variety of recent years 


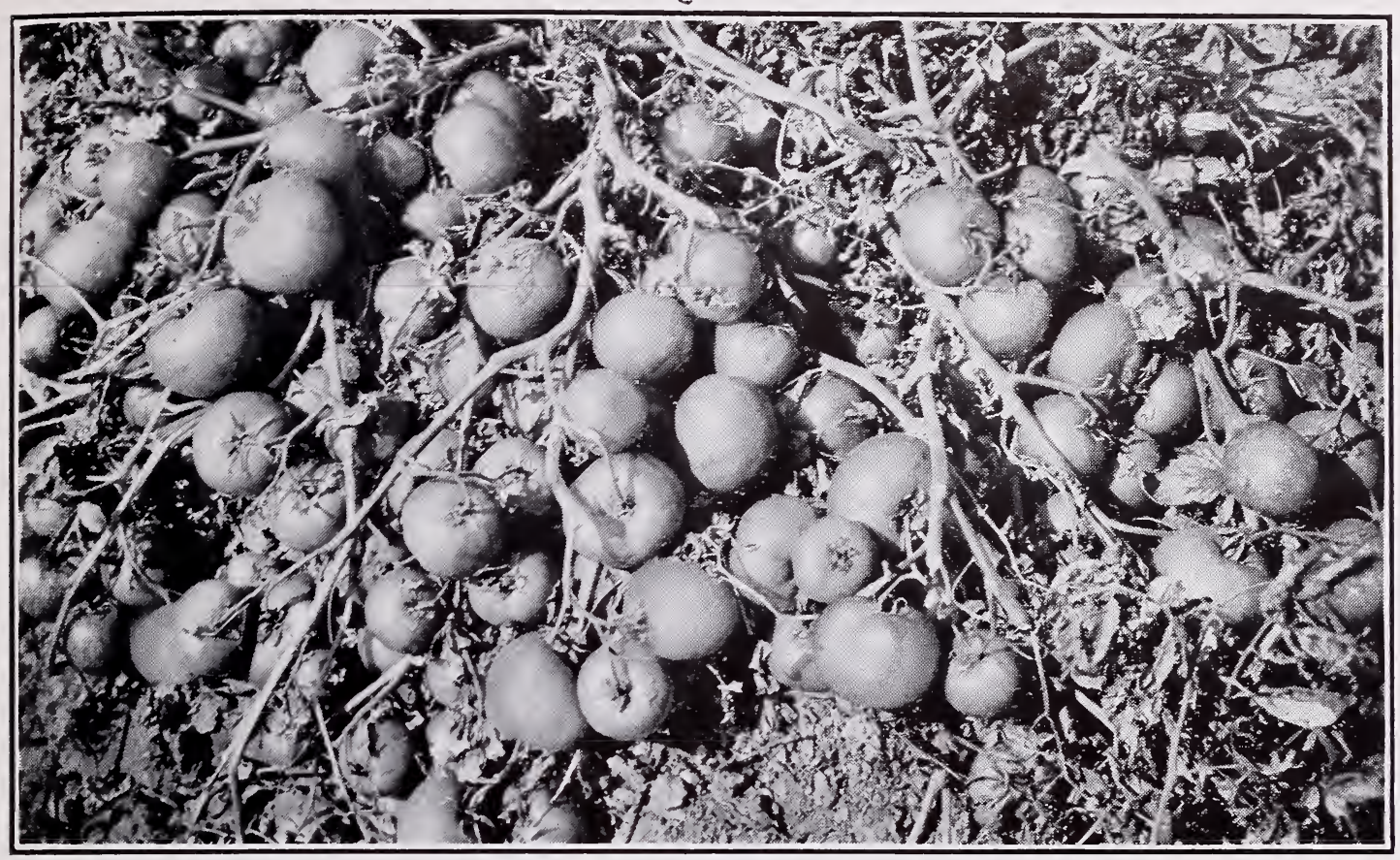

Pearson "C": A California variety. Foliage removed to show heavy set

Days

\section{SAN MARZANO (IMPROVED KING HUMBERT)}

A small fruited variety used for canning solid pack, paste, and puree, also for preserves. Vine medium, rather open, very prolific. Fruits largely rectangular, $31 / 2$ " long $\times 11 / 2 "$, two-celled, borne in clusters, deep red, with little juice and of very mild flavor. The Asgrow strain is notably thick, uniform and solid.

\section{SCARLET DAWN}

Developed at the Asgrow Eastern breeding station from a cross of Clark's Early and Marglobe; earlier in season than either parent. All-America Gold Medal for 1935. Vine of medium growth, fairly open, very prolific. Fruits medium large with thick wall structure, globular, smooth, free from flat sides; bright scarlet, ripening well to the stem, exceptionally attractive. Handsome in appearance and very uniform.

\section{STOKESDALE}

Introduced by the Francis C. Stokes Co.; an attractive second early variety of wide adaptability and heavy yielding ability. Fruits smooth and practically spherical, medium large in size and of good red color.

\section{STONE, IMPROVED}

Vine large, dense, very productive. Fruits large, flattened but deep, smooth, attractive scarlet-red of fine flavor. The Asgrow strain ripens evenly and is uniform.

\section{SMALL FRUITED}

Red or Yellow Cherry, Pear and Plum-a variety of shapes in either color, very prolific and disease-resistant. 


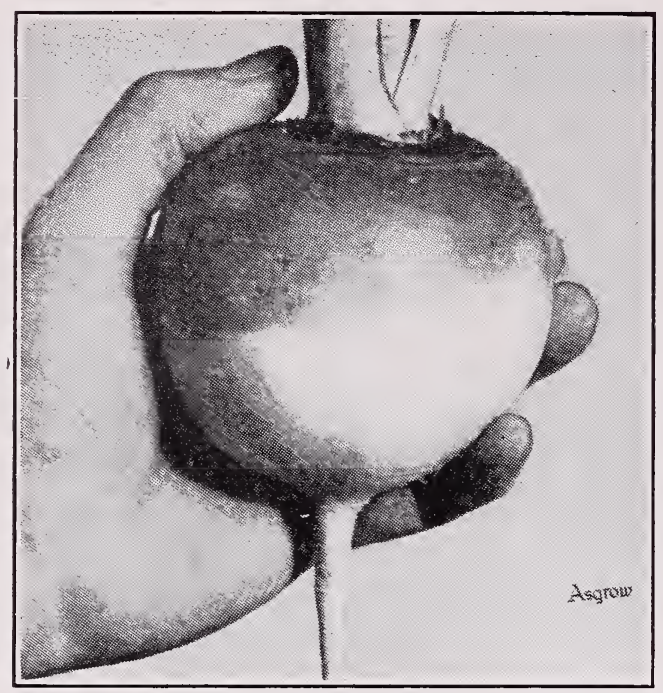

Purple Top White Globe:

the popular turnip

\section{TURNIP}

The number of days represents the time required from sowing of seed to roots of marketable or storage size, at our Eastern breeding station, Milford, Connecticut. The Asgrow pure bred stocks of the leading varieties are standards of quality.

PURPLE TOP WHITE GLOBE

Diameter
inches

4

Days

The most popular variety for general use. Tops dark green, large, erect, cut leaved. Roots large, globe-shaped, very smooth, upper part purple-red, white below; flesh white, sweet, crisp and tender. The Asgrow strain is very uniform and attractive.

\section{SEVEN TOP}

A very hardy sort used in the South for canning "greens." The young shoots are very tender; roots tough and unsuitable for food.

SHOGOIN (JAPANESE FOLIAGE)

A popular fast growing variety, for early greens and small roots. Tops 18"-20" tall, erect, bright green, strap leaved. Roots semi-globular, white throughout, mild and tender.

WHITE EGG

Tops medium sized, upright, cut leaved. Roots white, eggshaped, 3"-31/2" long, white throughout; smooth, fine grained, and of fine quality.

\section{RUTABAGA: SWEDE TURNIP}

\section{AMERICAN PURPLE TOP}

Also called Long Island Improved. A dependable variety; keeps well in storage. Roots large, globular, inclined toward top shape with relatively small neck; yellow with purple top; flesh light yellow, firm, of good texture and quality.

\section{WATERMELON}

CITRON, GREEN SEEDED (COLORADO PRESERVING)

Weight pounds

12

Days

Used only for preserving: extremely productive. Fruits round with alternate dark and light green striping. Flesh white and solid; seed quite heavy, smooth, glossy green.

CITRON, RED SEEDED

Practically identical with Green Seeded Citron, except slightly smaller and with bright red seed. Used for preserving. 


\title{
Associated Seed Growers, Inc.
}

Main OfFice: New Haven. Connecticut

\author{
Consolidating \\ THE EVERETT B. CLARK SEED CO., Est. 1857 \\ N. B. KEENEY \& SON, INC., \\ JOHN H. ALLAN SEED CO., 1856
}

Growing stations and warehouses at

Bozeman, Montana

Elgin, Oregon

Fairfield, Montana

Fairfield, Washington

Filer, Idaho

Gervais, Oregon

Greeley, Colorado

Hamilton, Montana

Kalispell, Montana
Brooks, Alberta, Canada
LeRoy, New York
Milford, Connecticut
Mt. Vernon, Washington
Powell, Wyoming
Ronan, Montana
Salinas, California
Sheboygan, Wisconsin
St. Anthony, Idaho
St. Paul, Minnesota

Breeding stations at

Franklin, Indiana

Hamilton, Montana

Milford, Connecticut
Milpitas, California

Palmetto, Florida

Robstown, Texas

Twin Falls, Idaho

Sales branches and distributing warehouses at

Atlanta, Georgia

Cambridge, New York

Indianapolis, Indiana

Los Angeles, California
Memphis, Tennessee Milford, Connecticut Oakland, California Salinas, California

Distributors for Texas

ASSOCIATED SEEDS, INC.

San Antonio Robstown Weslaco

ASSOCIATED SEED GROWERS, INC., gives no warranty, express or implied, as to the productiveness of any seeds or bulbs it sells, and will not be responsible for the crop. Its liability, in all instances, is limited to the purchase price of the seeds or bulbs. 


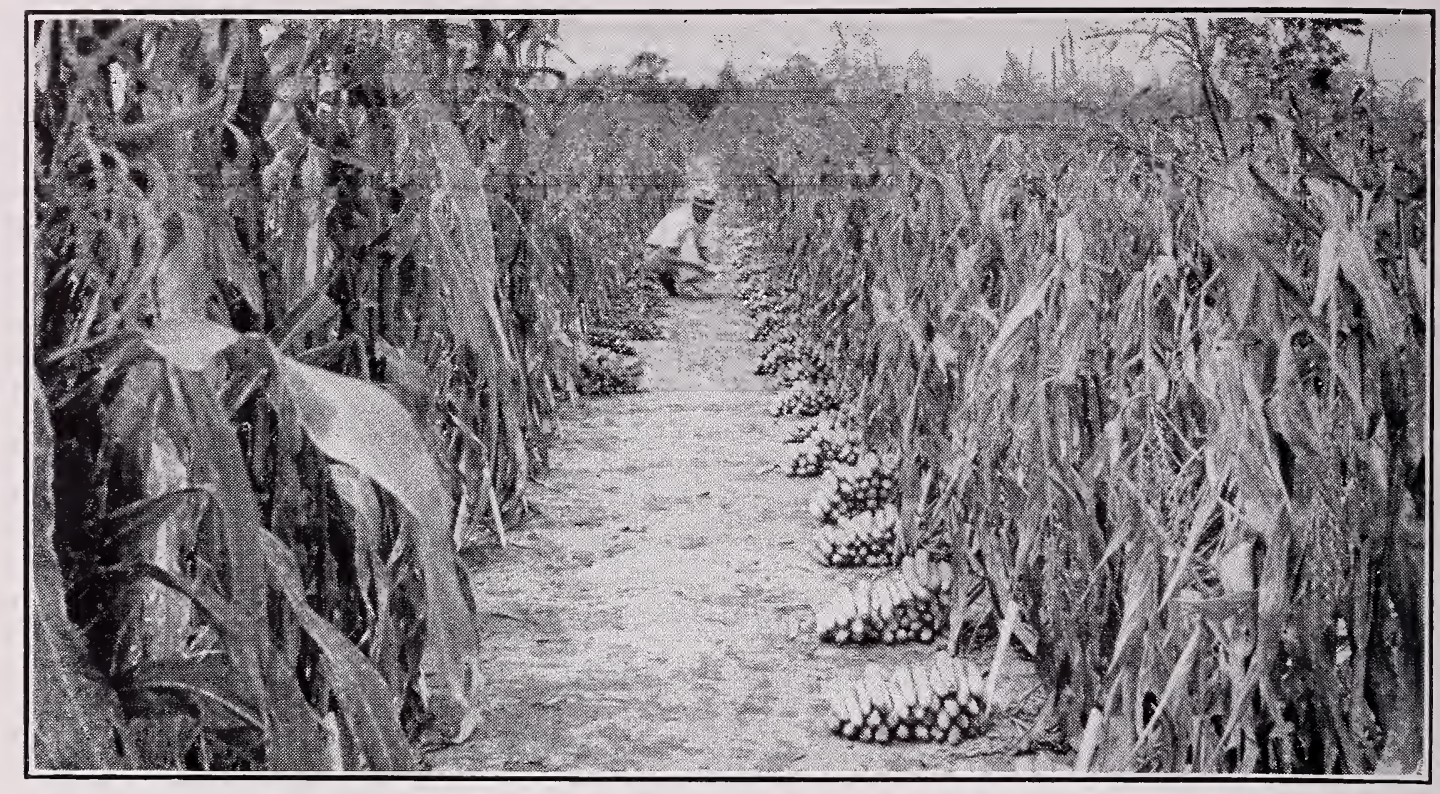

Corn trials: Asgrow Midwestern breeding station, Franklin, Indiana
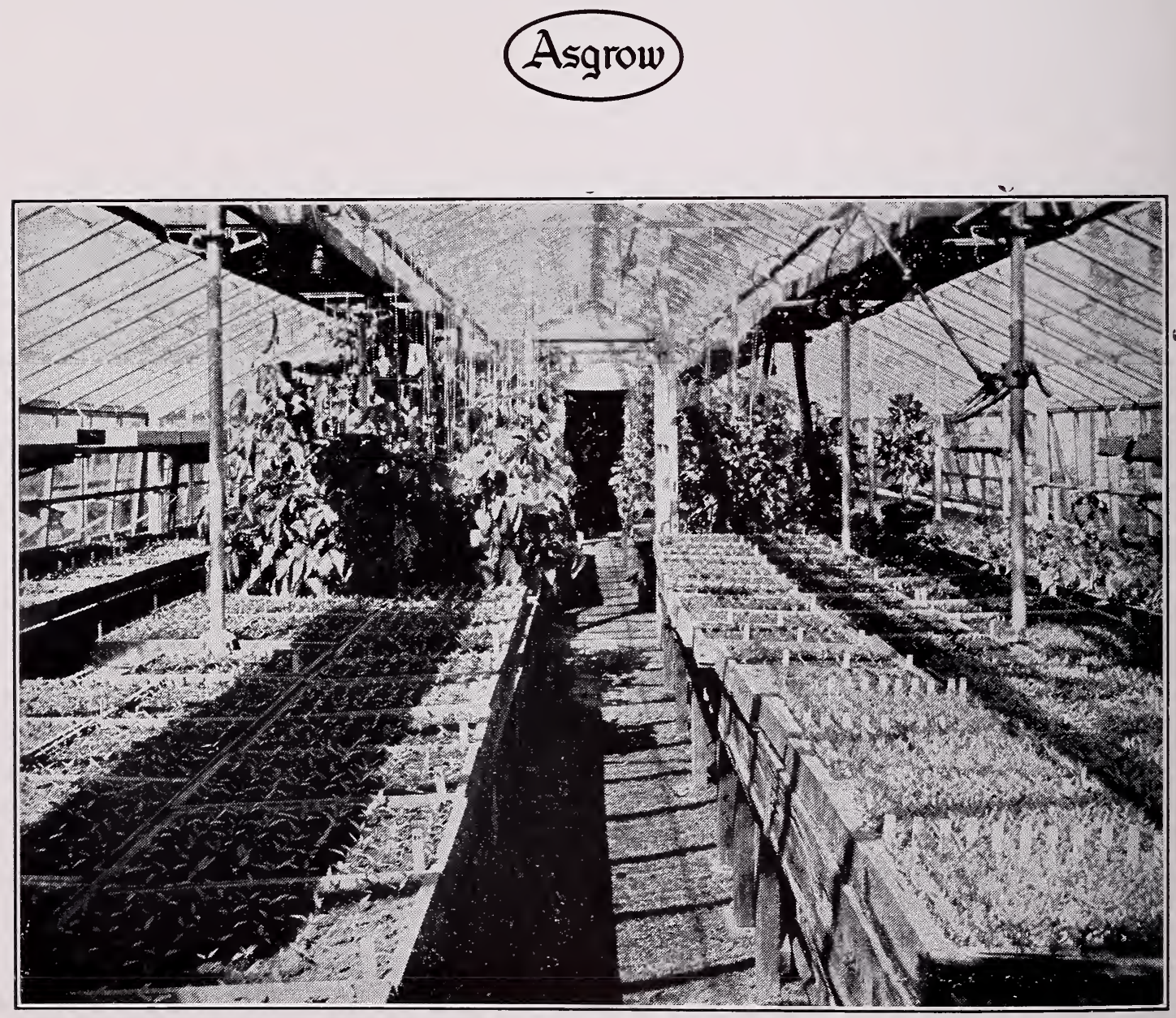

Greenhouse at one of the Asgrow breeding stations 
